\title{
Article
}

\section{The Late Eighteenth Dynasty Tomb of Ry at Saqqara (reign of Tutankhamun). Horemheb's Chief of Bowmen and Overseer of Horses Contextualised}

\author{
Nico Staring
}

This article presents the Saqqara tomb of Ry, an army official who built his funerary monument in the immediate post-Amarna period (temp. Tutankhamun, c. 1319-1310 BCE). The Leiden-Turin Expedition to Saqqara excavated this anonymous mud-brick tomb structure in 2013. Recent research revealed that various decorated limestone revetment blocks held in museum collections around the world derive from this tomb. They were removed by early excavators almost 200 years ago and formed part of the antiquities collections of prominent collectors such as Giuseppe Passalacqua and Henry Abbott. The dispersed tomb elements bearing texts and iconography are here contextualised and the funerary monument is analysed in the framework of the development of the Memphite New Kingdom necropolis.

يقدم هذا المقال مدفن ري في سقارة، مسؤول بالجيش بنى لنفسه المدفن في فترة ما بعد العمارنة مباثرة (فترة نوت عنخ أمون، حوالي 1319-1310 قبل الميلاد). قامت بعثات ليدن وتورينو في عام 2013 بتنقيب هذا المدفن المجهول في سقارة، وهو مبني بالطوب الطيني. كثفت الأبحاث الحديثة أن العديد من لوحات الحجر الجيري المزخرفة والمنتشرة في عدة متاحف حول العالم أصلها من هذا المدفن. لقد نم نقلها أثناء الحفريات المبكرة قبل مئتان عام تقريباً وكانت جزءاً من المجموعات الأثرية لهواة جمع الآثار البارزين مثل جوزيبي باسالاكوا وهنري أبوت. العناصر المبعثرة لهذا القبر تحمل نصوصاً وأيقونات مختلفة، في هذا النص تم جمعها ودر استها وتحليل الغرفة الجنائزية في إطار تطور مقابر ممفيس خلال فترة الدولة الحديثة.

\section{Recent archaeological research in the Unas South Cemetery: On the accidental discovery of a New Kingdom tomb}

The modern investigation of the late Eighteenth Dynasty tomb subsequently identified as belonging to $\mathrm{Ry},{ }^{1}$ Chief of Bowmen and Overseer of Horses, started in 2002. At the time a joint archaeological mission between Leiden University and the National Museum of Antiquities in Leiden, the project was focused on the underground burial spaces of the late Eighteenth Dynasty tomb of Meryneith (Fig. 1, 2). This monument is situated in the south sector of the
Unas South Cemetery at Saqqara. The underground burial spaces of Meryneith connected to a complex of corridors and chambers of a Second Dynasty tomb. It provided the excavators access to a further maze of underground passages cut into the rock during various periods of Egyptian history. From one such passage the excavators entered burial chambers dating to the New Kingdom, situated south of Meryneith (feature no. 2002/17). ${ }^{2}$ It was suggested that these underground chambers were connected to the remains of a mud-brick chapel located in an area due east of the tomb built by Pay and his son 


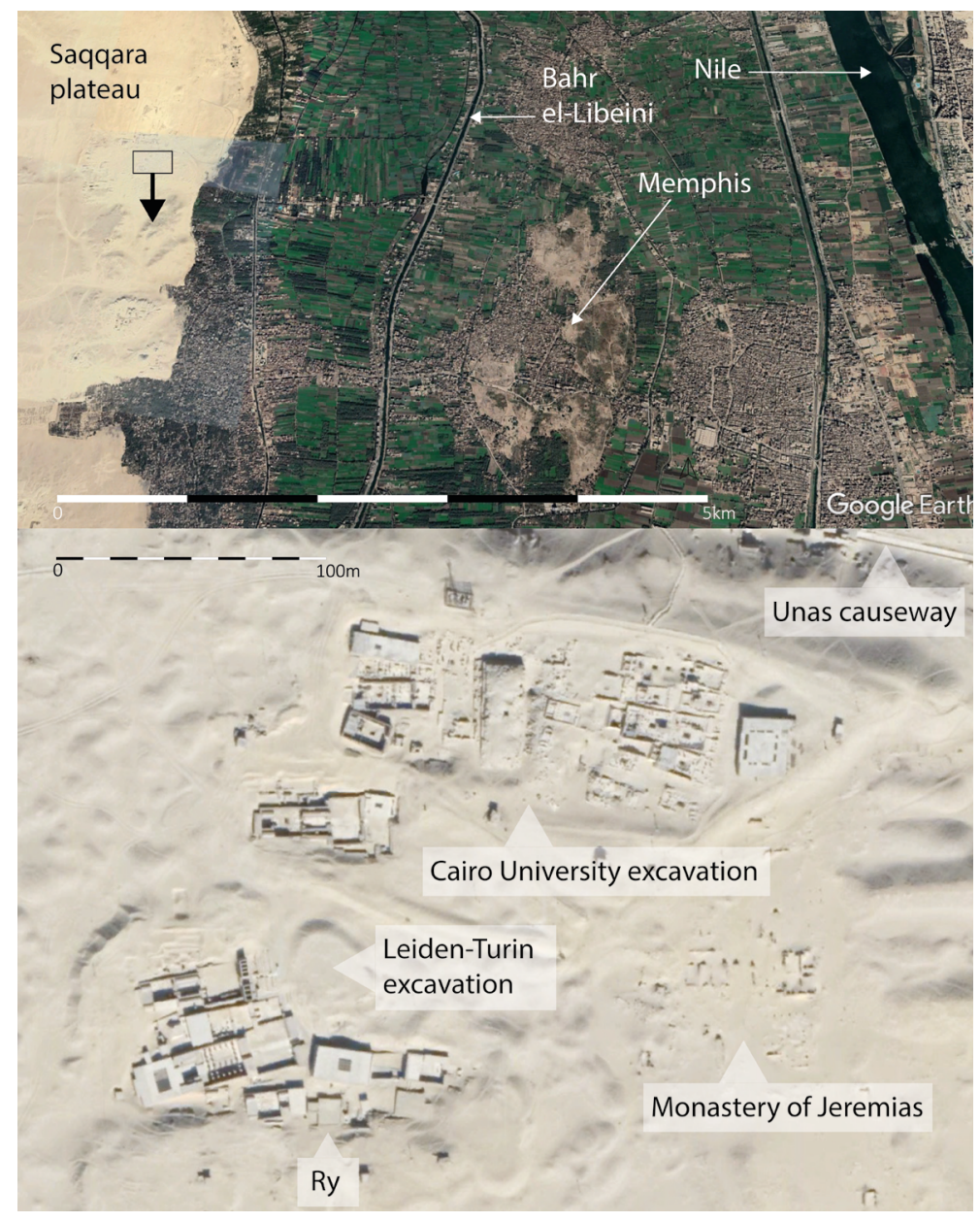

Fig. 1: The tomb of Ry in its spatial context. Images: Google Earth 2018, adapted by the author.

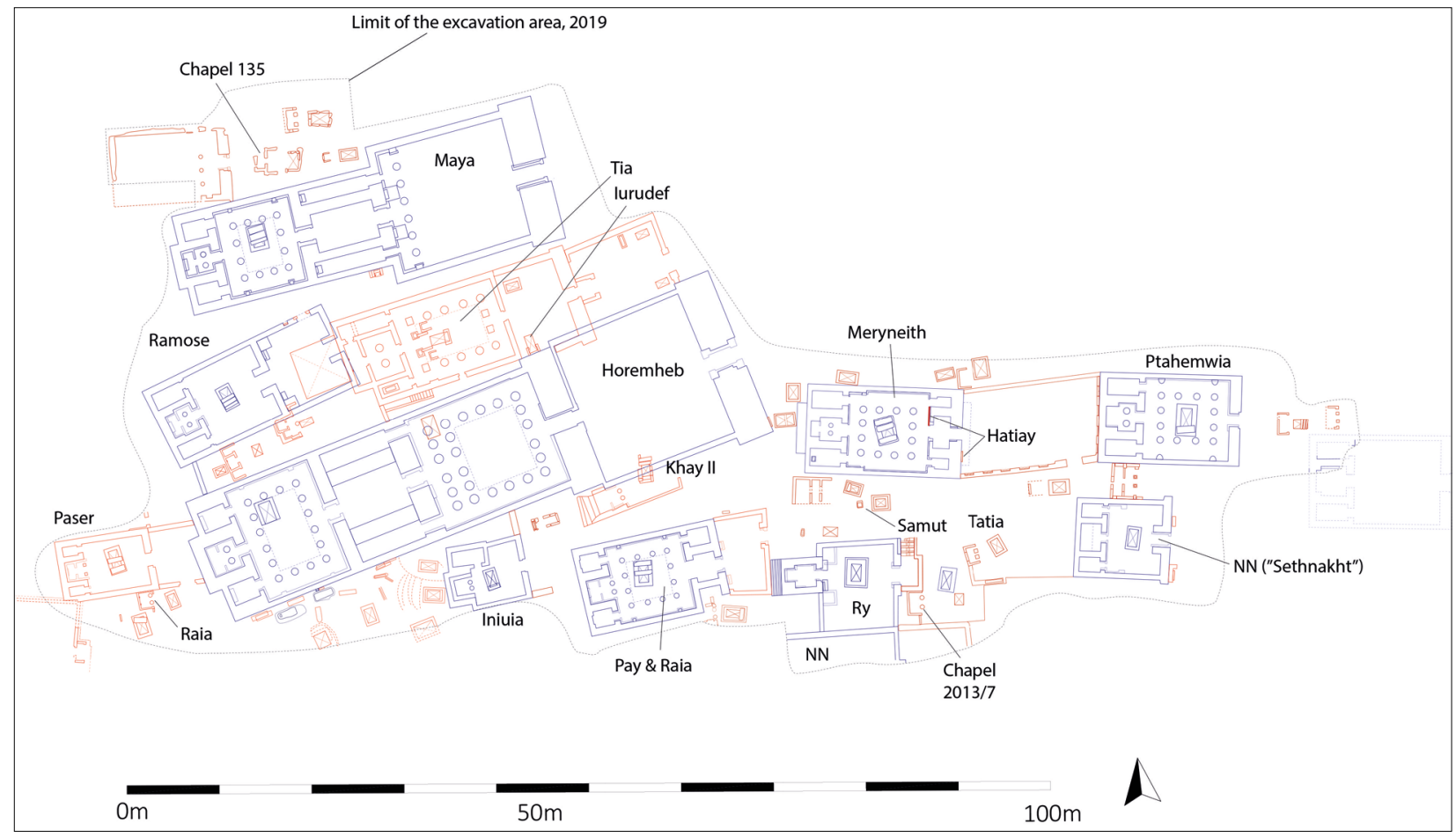

Fig. 2: Map showing the location of New Kingdom tombs in the south section of the Unas South Cemetery, Leiden-Turin concession area, 2019. The tombs coloured in blue are of late Eighteenth Dynasty date; those coloured in red date to the Ramesside period. Image by Nico Staring, after tomb plans by Kenneth Frazer, Willem Beex, Annelies Bleeker, Pieter Collet, and Paolo Del Vesco. 


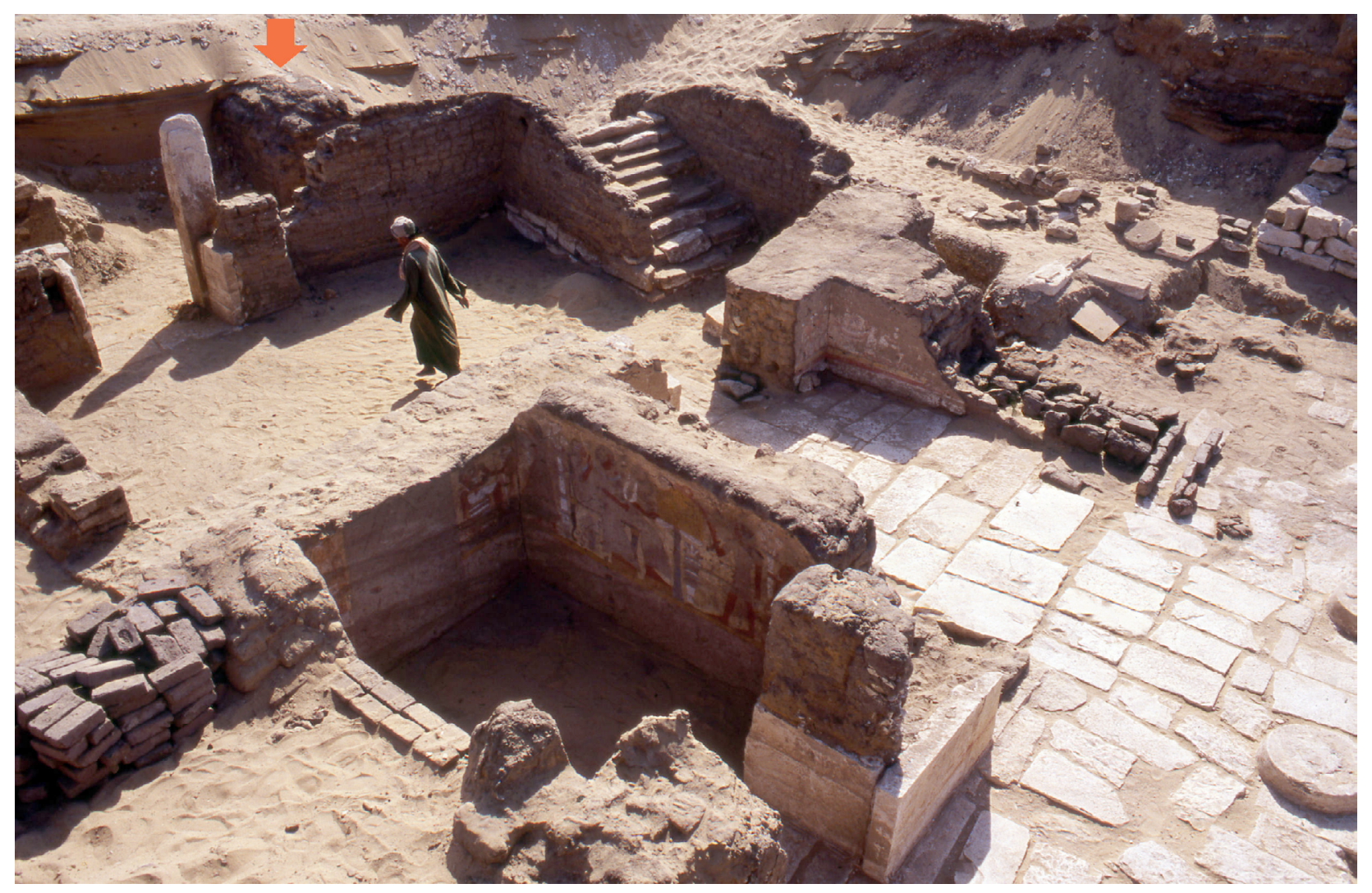

Fig. 3: View of the tomb of Pay and Raia at the end of the EES-Leiden excavation season of 1994, looking south-east. The arrow indicates the mud-brick remains of a tomb chapel in front of the forecourt built by Raia. Photo @Rijksmuseum van Oudheden, Leiden, adapted by Nico Staring.

Raia. Parts of that chapel had been seen protruding from the desert sand when the former joint mission of the Egypt Exploration Society and the National Museum of Antiquities in Leiden worked there in 1994 (Fig. 3). ${ }^{3}$ At the time, it was decided not to further excavate the chapel. As a result of that decision, the chapel gradually disappeared under the sand. The burial chamber in underground complex $2002 / 17$ was fully excavated in 2002. Originally it would have been entered through a tomb shaft which led into an antechamber. A descending stairway then gave access to the burial chamber. ${ }^{4}$ The latter space yielded no inscriptional evidence to identify the original tomb owner. Instead, the excavators found a 20-cm-thick layer of dark fill at floor level. It contained New Kingdom pottery, decayed wood, glass beads, and flakes of gold leaf. ${ }^{5}$ There were also several fragments of loose relief-decorated blocks that had fallen down the burial shaft at some time. Some of these blocks had been subsequently brought into the subterranean spaces to be reused in secondary burials. The blocks included one specimen inscribed for a Ramesside official named Mery-Iunu. ${ }^{6}$ Another block was shown to derive from the nearby tomb of Tia, the brother-in-law of Ramesses II. ${ }^{7}$ The pottery collected from the dark fill at floor level in the burial chamber was dated to the Eighteenth Dynasty. ${ }^{8}$

\section{Observations on the architecture of the tomb}

The area of the cemetery situated south of the tomb of Meryneith and east of Pay and Raia was not excavated until 2013. During a short season of fieldwork, the perimeter walls of a mud-brick superstructure were cleared from the sand. ${ }^{9}$ In the next fieldwork season, in 2015, the tomb shaft was cleared and the underground complex 2002/17 once again entered. ${ }^{10}$ The fill of the shaft (consisting of sand and debris) did not yield evidence to identify the tomb owner. Therefore, the anonymous structure was henceforth referred to in the literature as "tomb X". The east-west oriented superstructure built of mud bricks consists of a gateway, an open courtyard, and a single cult chapel to the west (Figs. 4-7). The south wall of the courtyard is formed by the pre-existing north exterior wall of Ry's presumed neighbour to 


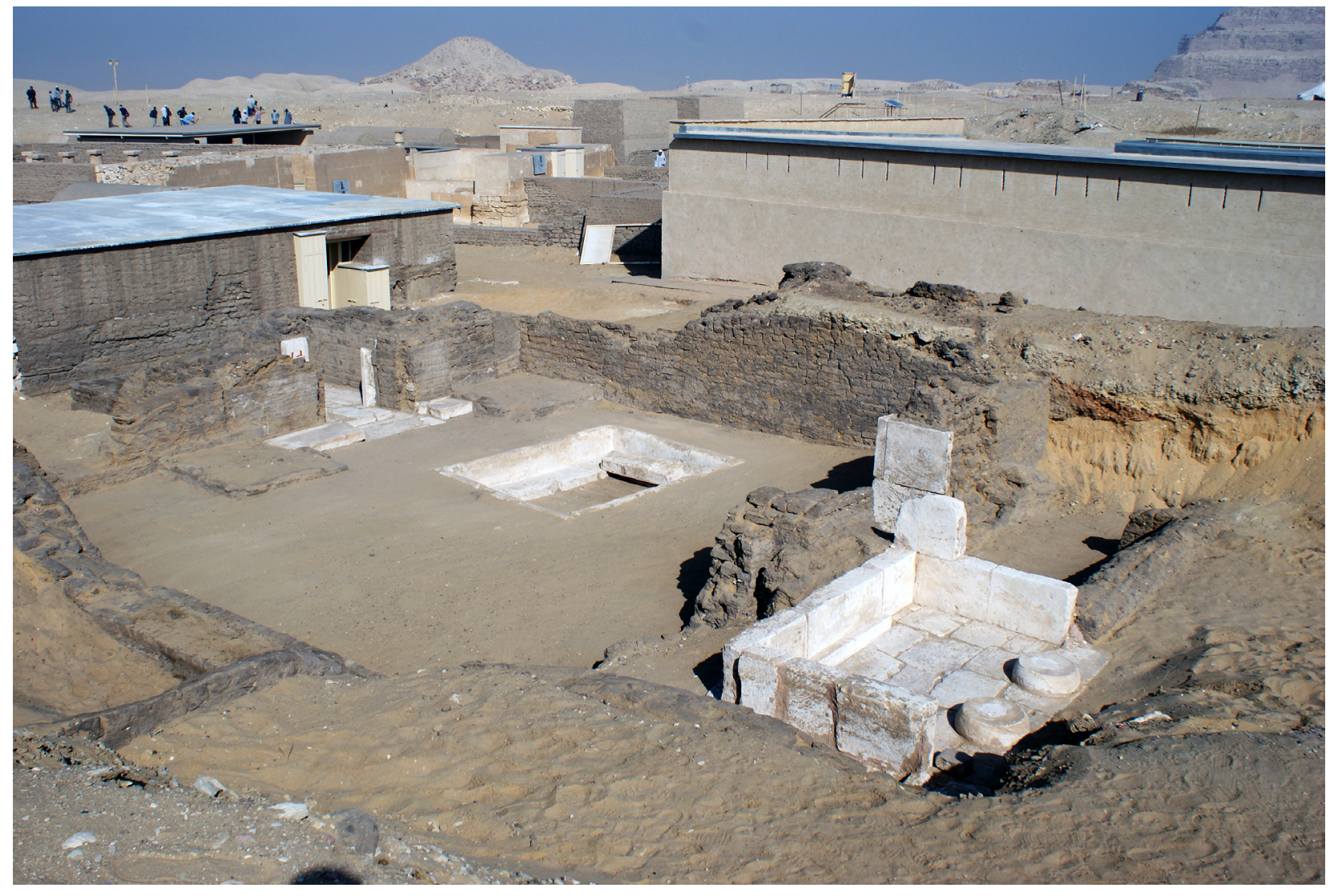

Fig. 4: The tomb of Ry, photographed at the end of the 2013 excavation season, looking northwest. Photo by Nico Staring.

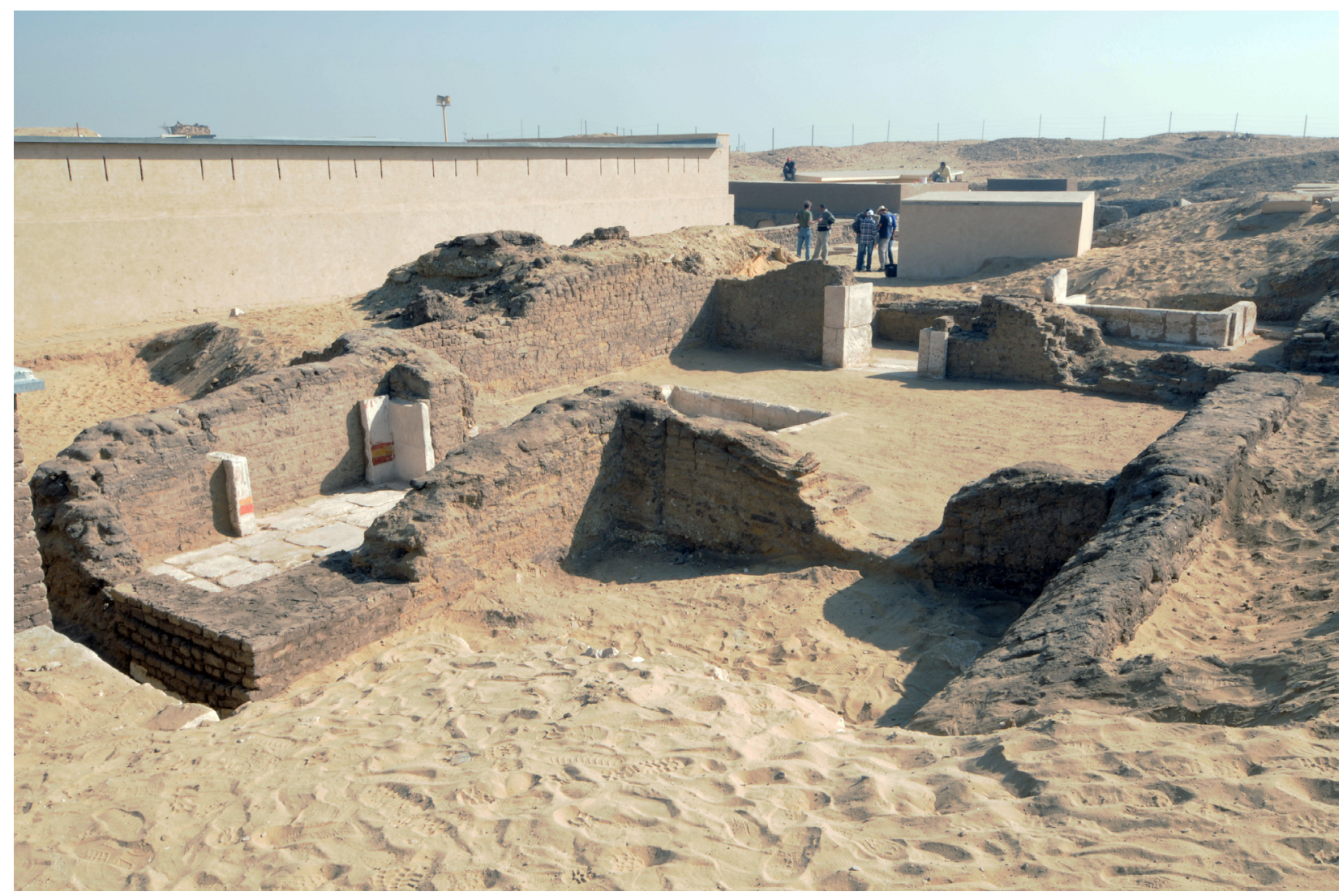

Fig. 5: The tomb of Ry, photographed at the end of the 2013 excavation season, looking northeast. The southwest corner of the chapel (visible in the foreground) had been completely removed, possibly in the 1820s, and was reconstructed in 2013. Photo ๑Rijksmuseum van Oudheden, Leiden/Anneke de Kemp. 


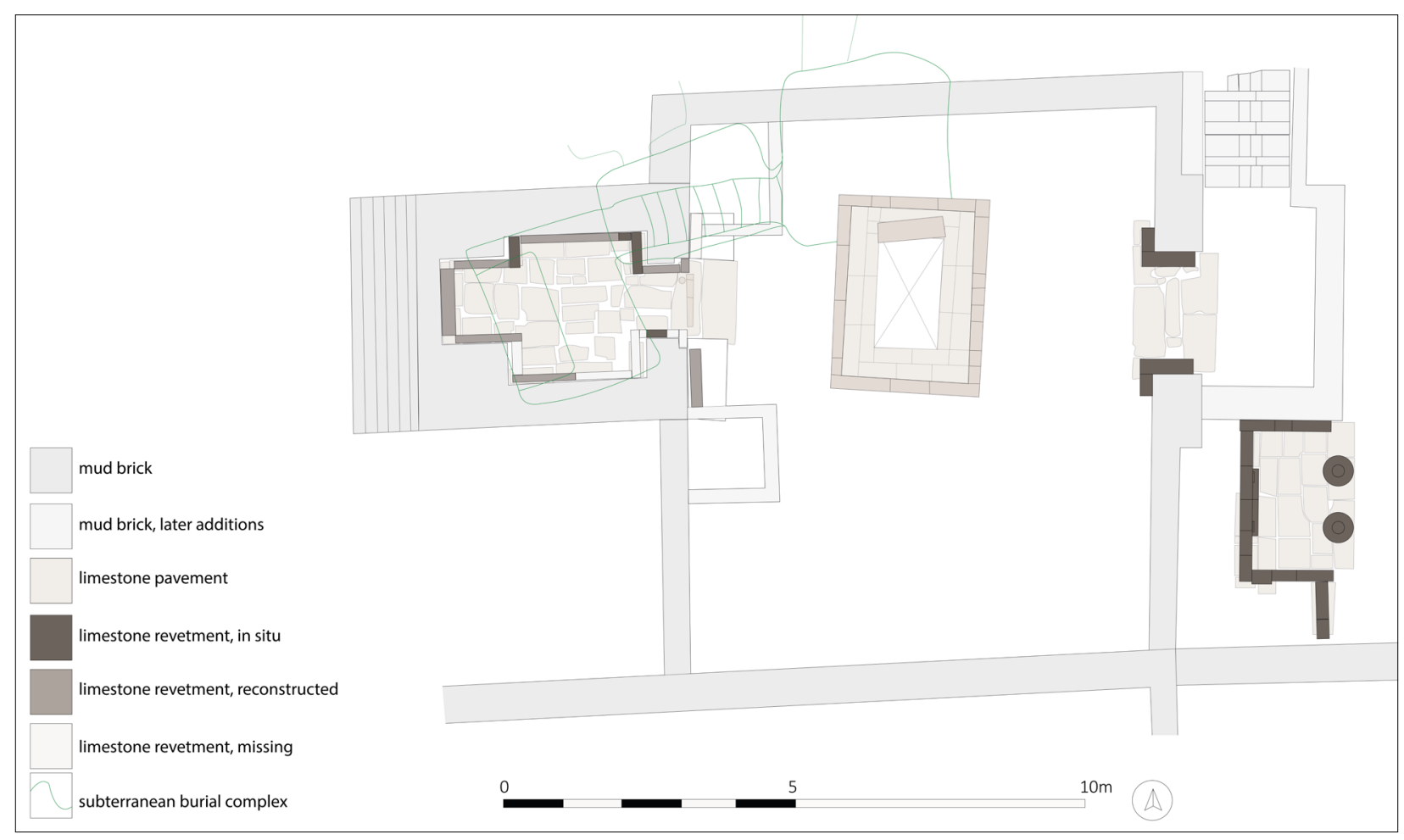

Fig. 6: Plan of the late Eighteenth Dynasty tomb superstructure and substructure of Ry and of the anonymous Ramesside chapel, feature 2013/7. Photo by Nico Staring.

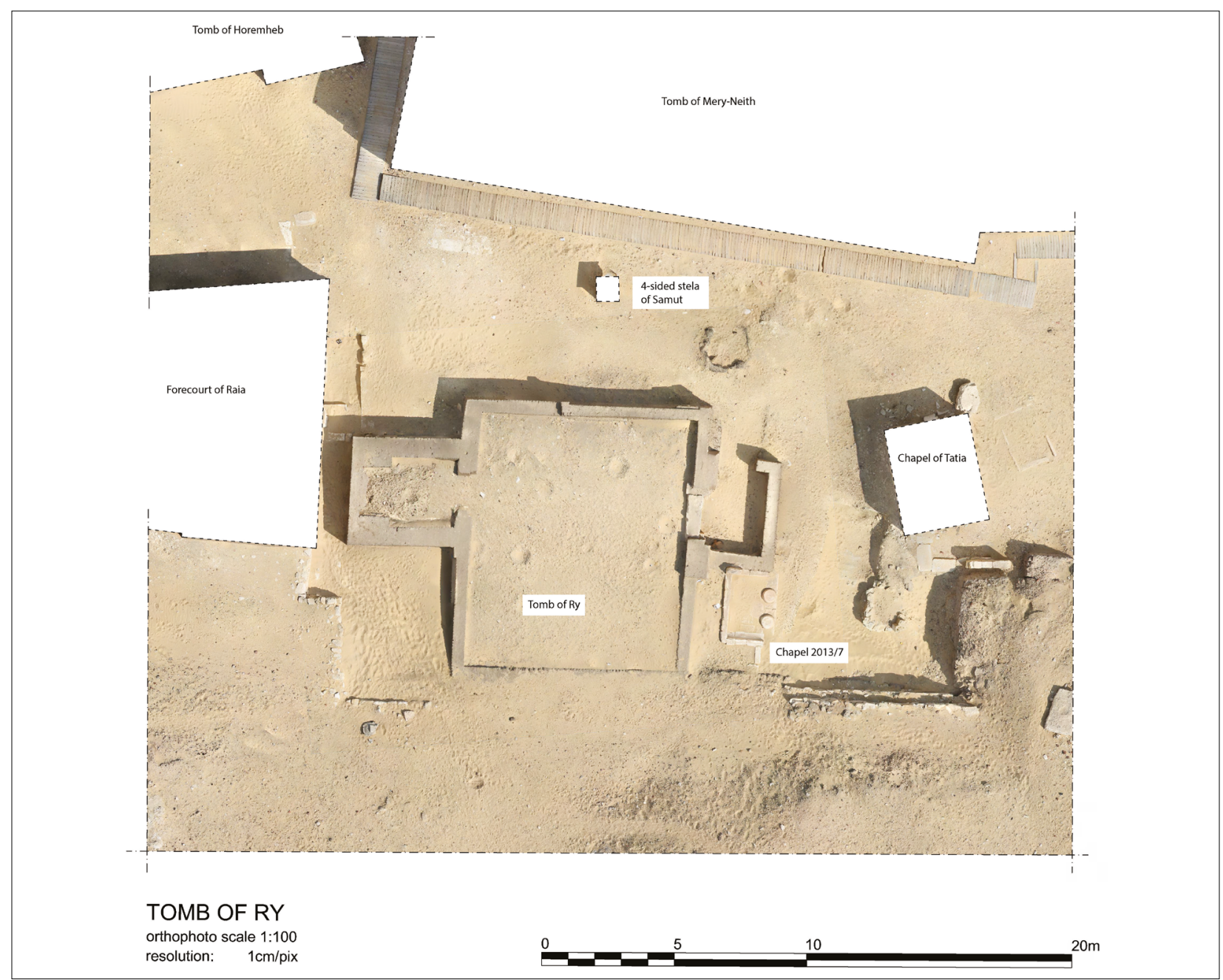

Fig. 7: Aerial view of the tomb of Ry in 2019, showing the situation after restoration, consolidation, and backfilling of the structure. Orthophoto by 3D Survey Group, Department ABC, Politecnico di Milano/Leiden-Turin Expedition to Saqqara. 


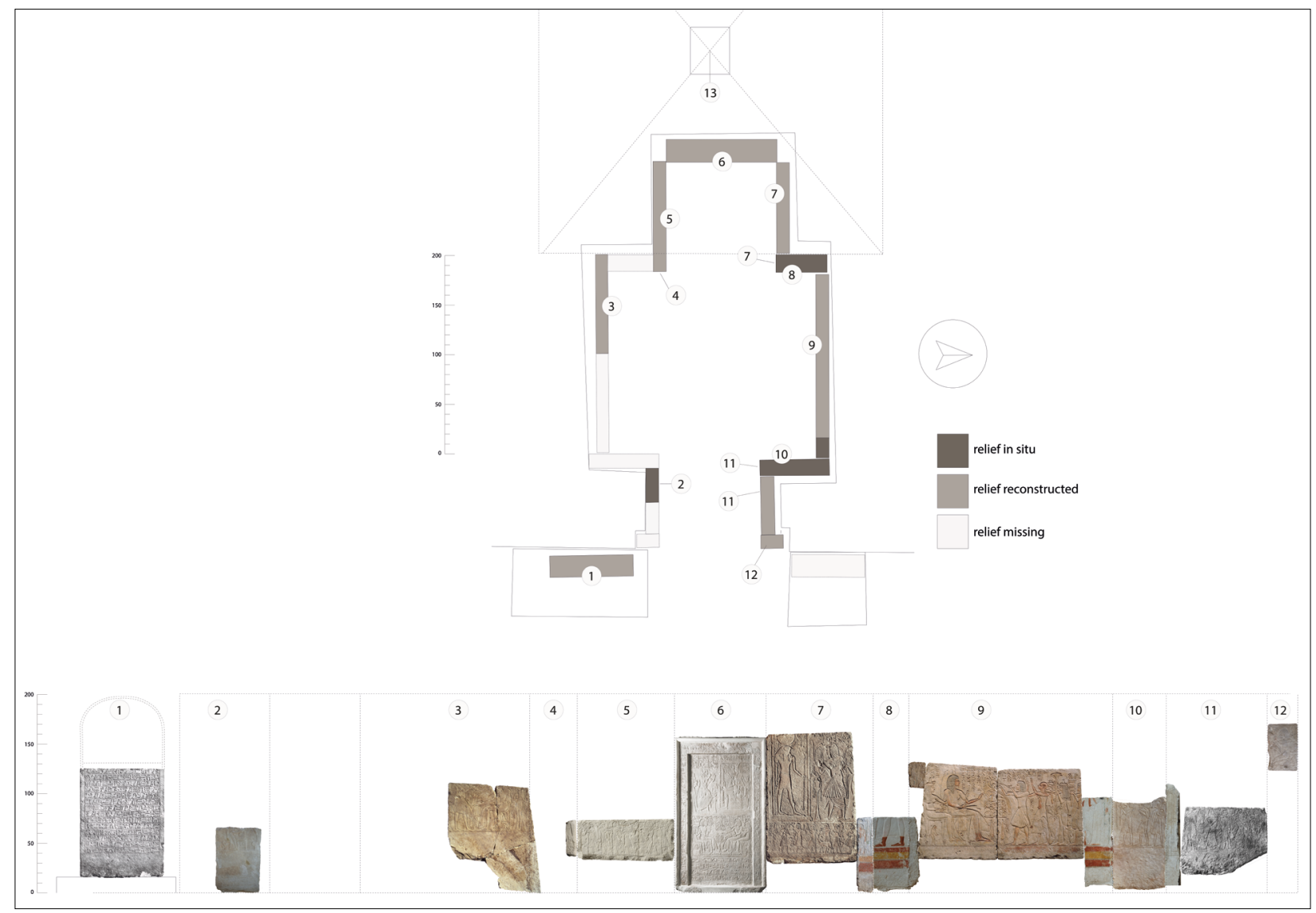

Fig. 8: A reconstruction of the iconographic programme of Ry's tomb chapel. Image by Nico Staring.

the south. The east and west walls of the tomb are not bonded with this pre-existing wall. ${ }^{11}$ The overall layout of Ry's tomb is somewhat asymmetrical. The tomb entrance, burial shaft and west chapel are aligned, but the entrance to the cult chapel is not situated in the centre of the courtyard's west wall. The walls of the courtyard are not bonded with the walls of the chapel, which might indicate that the courtyard was built sometime after the chapel. At an even later stage, a north-south-oriented "porch" was added to the east gateway. ${ }^{12}$ This annex delimited by an L-shaped wall, clearly not part of the tomb's original design, is broadest in front of the tomb entrance. The narrower north extension has a mud-brick floor which descends from an elevated exterior surface. ${ }^{13}$ The single cult chapel in the west part of the tomb may seem to be unusual when compared to the similarly-sized tomb structures located in the same section of the necropolis. ${ }^{14}$ Indeed, most of the tombs excavated to date have three chapels. The layout of the tomb of Ry, however, is comparable to that of the nearby tomb of Iniuia (temp. Akhenaten-Tutankhamun), which compris- es an open court and a main chapel to the west (as well as a second, vaulted chapel in the northwest corner). ${ }^{15}$ There are numerous other examples of tombs comprising a single chapel with a forecourt in the Teti Pyramid Cemetery; it should be noted, however, that they are considerably smaller. ${ }^{16}$

The tomb superstructure measures ca. $17 \mathrm{~m}$ in length (including the annex) and ca. $11 \mathrm{~m}$ in width. A large, rectangular tomb shaft off the centre of the courtyard gives access to the subterranean complex, which is situated at a depth of ca. $8 \mathrm{~m}$. One of the shaft's covering slabs was found in its original position. The courtyard provides traces of a rubble floor and the interior walls were originally plastered. Limestone floor slabs and limestone revetment of interior walls are limited to the entrance doorway and the cult chapel; these are the only parts of the tomb bearing a relief decoration. ${ }^{17}$ Stone bases originally supporting stelae are preserved on either side of the entrance to the west chapel. A remarkable feature connected to (and partly built over) them is low enclosures built of mud bricks. ${ }^{18}$ These features, excavated in 2015 , contained a large amount 


\begin{tabular}{|l|}
\hline I. Reliefs \\
\hline I.1 Berlin, Ägyptisches Museum und Papyrussammlung ÄM 7275 \\
\hline I.2 Berlin, Ägyptisches Museum und Papyrussammlung ÄM 7277 \\
\hline I.3 Berlin, Ägyptisches Museum und Papyrussammlung ÄM 7278 \\
\hline I.4 Brooklyn Museum 37.39E \\
\hline I.5 Jerusalem, Studium Biblicum Franciscanum Museum CTS-SB-06202 \\
\hline I.6 Saqqara R94-78 \\
\hline I.7 Saqqara 2013-R35 \\
\hline II. Stelae \\
\hline II.1 Berlin, Ägyptisches Museum und Papyrussammlung ÄM 7290 \\
\hline II.2 Brooklyn Museum 37.46E \\
\hline III. Architectural elements \\
\hline III.1 Cairo, Egyptian Museum JE 14975 (pyramidion) \\
\hline
\end{tabular}

Table 1: Stone tomb elements deriving from the tomb of Ry at Saqqara.

of broken offering pottery dating to the late Eighteenth Dynasty. ${ }^{19}$ It included red funnel-necked jars and blue-painted ovoid jars. Their contents suggest that the platforms served as repositories for used offering pottery. Additional examples of such offering pottery from the Ramesside period was found at floor level in the tomb courtyard. ${ }^{20}$

The cult chapel is accessed through a $1.0 \mathrm{~m}$-wide doorway in the courtyard's west wall. ${ }^{21} \mathrm{~A}$ raised sill lies across the entrance and a pivot hole for a wooden door is situated on the north side of the doorway. The chapel walls were preserved to a height of ca. $1.3 \mathrm{~m}$. Their original height would probably have been in the range of ca. $1.5-2.0 \mathrm{~m} .^{22}$ The architectural layout includes an antechapel, $2.0 \mathrm{~m}$ deep and $2.28 \mathrm{~m}$ wide, and a narrower inner sanctuary, ca. $0.9 \mathrm{~m}$ deep and $1.25 \mathrm{~m}$ wide. The chapel's west wall had a thickness of ca. $1.7 \mathrm{~m}$. The inner chapel's thick walls, the now-missing lintel, the screen walls and the stone revetment presumably supported the roofing slabs upon which a mud-brick pyramid once stood. ${ }^{23}$ The thick walls surrounding the inner chapel may indicate that this pyramid only stood over the central chapel.

\section{Iconographic programme and texts}

The interior of the chapel originally had a limestone revetment bearing relief-decoration (Fig. 8). Fragments of four relief-decorated blocks were found in situ. Setting lines scratched into the limestone pavement point to the former presence of blocks that are now missing. None of the loose blocks found during the excavation could be assigned to the tomb with any certainty. More recently, a study conducted by the present author showed that two of the in-situ blocks were the keys to unlocking the identity of the tomb owner. ${ }^{24}$ The fragments on the north wall of the inner chapel and on the north wall of the antechapel show traces of depictions of offering bearers, which joined directly with depictions on blocks held in the collection of the Egyptian Museum in Berlin. This allowed the tomb owner to be identified, and to trace to the tomb further stone architectural elements held in various museums worldwide. The complete list of elements attributed to the tomb of Ry is given in Table $1 .^{25}$

Below is a description of the decoration programme of the tomb of Ry. The numbering of scenes starts in the courtyard and continues clockwise along the chapel walls. This article comprises primarily a study of the iconography and the architectural layout of the tomb. For this reason, I will limit myself in the treatment of the hieroglyphic texts. These are mostly dealt with elsewhere, and therefore a translation will suffice here. An exception is made for block Berlin ÄM 7278, because it bears a unique example of an excerpt from a Book of the Dead spell. The spell's relationship with the tomb's overall iconographic programme and architectural space unit are the subject of further study in this article. 
[1] Courtyard, west wall, south jamb of antechapel entrance: Stela Brooklyn Museum 37.46E (Fig. 9)

Limestone.

H. 111.5 cm, W. 85 cm, Th. 14.5 cm. ${ }^{26}$

Bibliography: NYHS, 1915, p. 2, no. 14; Fründt, FuB 3/2 (1961), p. 31; Stewart, BIA 6 (1966), pp. 54, 57, nos. IV, VI; Assmann, Liturgische Lieder, 1969, pp. 300, 376 (text III.3); James, Corpus of Hieroglyphic Inscriptions, 1974, pp. 178-79 [435], pl. 87.

\section{Description}

Fragment Brooklyn 37.46E is the lower part of a stela bearing fourteen lines of hieroglyphic text. Its contents are identified as three hymns to the sun god. ${ }^{27}$ In view of the orientation of the hieroglyphic signs, the stela stood against the south jamb of the doorway. As such, the individual signs faced towards the entrance.

\section{Text}

[May the $b a$ of the Chief of Bowmen, Ry, go out with you to the sky.] ${ }^{\mathbf{1}}$ May he set sail in the Day Bark, may he moor in the Night Bark, may he join the unwearying stars ${ }^{\mathbf{2}}$ in the sky. The Osiris, Chief of Bowmen, Ry, true of voice, he says as he praises the Lord of Eternity: "Hail to you, Re-Horakhty ${ }^{\mathbf{3}}$ this Khepri who created himself. How beautiful is your rising in the horizon when you illuminate the Two Lands with your rays! ${ }^{4}$ All the gods are in jubilation when they see you as the king of heaven. The Lady of Wenut is fixed on your head, ${ }^{\mathbf{5}}$ the crowns of Upper and Lower Egypt are on your brow. She has taken her place at your forehead. Thoth is established in the bow of your bark to ${ }^{6}$ destroy all your enemies. Those who are in the Netherworld come forth at your approach to see this ${ }^{7}$ perfect image of yours. I have come to you (because I want to be) with you so that I may see your body at beholding your perfection like all your praised ones, ${ }^{\mathbf{8}}$ because I am one of those who were honoured by you on earth. I have reached the land of perpetuity, I have joined ${ }^{9}$ the place of eternity (for) you allotted it to me, my lord." To the ka of the Osiris, the Chief of Bowmen, Ry, true of voice, he says: "Hail ${ }^{\mathbf{1 0}}$ to you, as you rise in your horizon as Re, (one) satisfied with Maat. When you cross the sky, all faces ${ }^{\mathbf{1 1}}$ are looking at you (although) your movements are hidden from their sight.

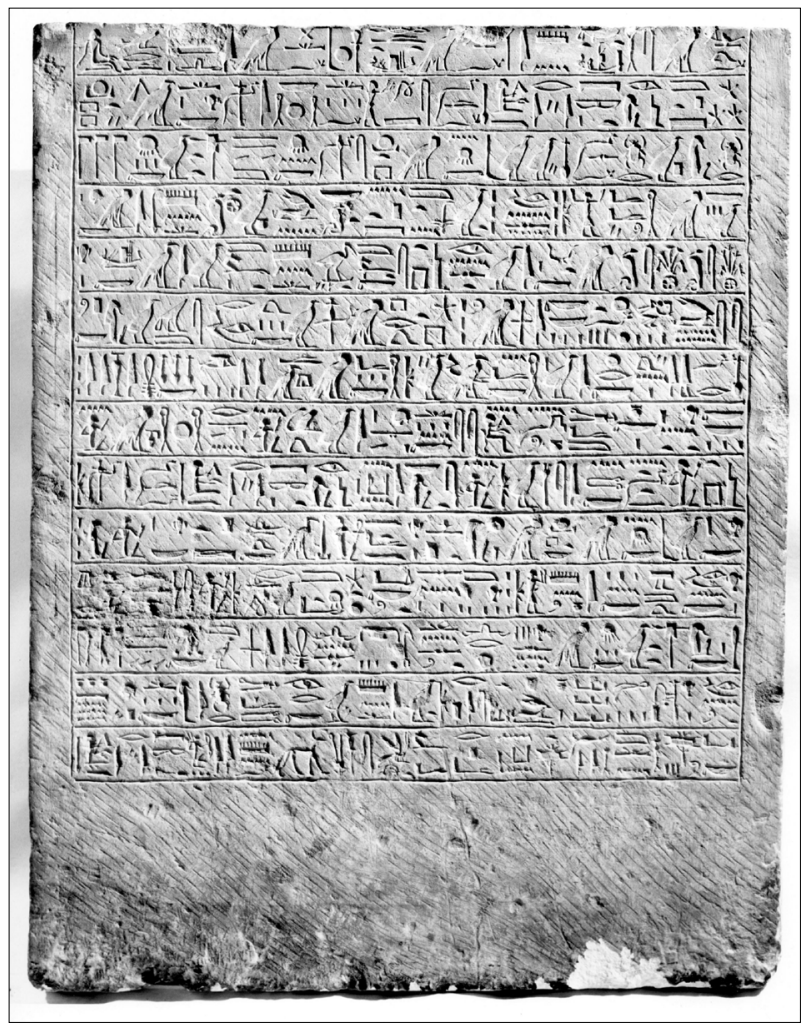

Fig. 9: Stela Brooklyn Museum 37.46E. Scan of a photograph held in The Martin New Kingdom Archive. @Brooklyn Museum.

When you show yourself in the morning every day, firm is the course under ${ }^{\mathbf{1 2}}$ Your Majesty. Your rays are in their faces (although) they do not know you. (Even) fine gold is not like your splendour. The lands of the gods ${ }^{13}$ about which one sees (i.e. reads) in writings, and the mountainous regions of Punt can inspect you while you are (still) hidden. You created (yourself) alone (as if) your manifestation was Nun. ${ }^{\mathbf{1 4}}$ May you grant a sweet breeze of the north wind to the ka of the Noble and Count, Seal Bearer of the King of Lower Egypt, Sole Companion, Sab of the Army, Chief of Bowmen, Ry, true of voice."

\section{Notes on Text and Translation}

Stelae carrying hymns to the sun god are not uncommon at Saqqara and these texts have received considerable scholarly attention. ${ }^{28}$ Yet there is one aspect that I would like to draw more attention to. Three tombs situated in the same general area of the necropolis contained a total of four stelae offering close parallels to the hymns carved on the stela of Ry. These parallels are presented in Table 2. It should be noted that only stela JE 10079 of Iniuia is preserved in its entirety. 


\begin{tabular}{|c|c|c|c|c|}
\hline \multirow[b]{2}{*}{ Ry: Brooklyn 37.46E } & \multicolumn{4}{|c|}{ Saqqara parallels } \\
\hline & Lines & Stela & Tomb owner & Title of office \\
\hline Line $x+1$ to $x+8$ & 5 to 12 & Saqqara ${ }^{29}$ & Iniuia & im.y-rз $p r w r \mid$ im.y-rз ih.w ${ }^{2} n . w^{\prime} \operatorname{Imn}$ \\
\hline line $x+9$ to $x+13$ & 2 to 7 & Cairo JE $10079^{30}$ & Iniuia & \\
\hline line $x+1$ to $x+12 / 13$ & 3 to 10 & $\begin{array}{l}\text { Saqqara + MMA } \\
04.2 \cdot 527^{31}\end{array}$ & Pay & $\begin{array}{l}\text { im.y-rз ip.t nsw.t n Mn-nfr } \\
\text { im.y-rз ih.w n.w'Imn }\end{array}$ \\
\hline line $x+5$ to $x+12 / 13$ & $x+1$ to $x+8$ & Vatican $251^{32}$ & Ptahmose & im.y-rз ip.t nsw.t \\
\hline
\end{tabular}

Table 2: Parallels for the sun hymns on stela Brooklyn 37.46E as attested in the tombs surrounding Ry in the Unas South Cemetery.

The two stelae of Iniuia originally stood in the open courtyard of the tomb, on either side of the entrance to the antechapel. Stela JE 10079 stood on a limestone base set against the north jamb of the entrance. The lunette depicts a double adoration scene of Iniuia standing with his hands raised in adoration before Atum (on the right) and Re-Horakhty (on the left). The main body of the stela includes a hieroglyphic text in twelve lines.

The second stela of Iniuia is reconstructed from 20 stone fragments recovered during excavation. The stela originally stood against the south jamb of the antechapel entrance. From the fragments, twelve lines of hieroglyphic text can be reconstructed. The right-hand side of the lunette preserves a scene of Iniuia standing in adoration before Re-Horakhty. The stela of Pay was also found in pieces during excavation. The hymn is composed of 21 lines of hieroglyphic text. The individual signs of the hieroglyphic texts carved on tomb walls, door jambs, and stelae are usually oriented towards the central axis of the tomb. Thus, in view of the orientation of the individual signs, which are facing right, the stela stood against the south jamb of the antechapel entrance. ${ }^{33}$ As such, the hieroglyphic signs faced the doorway. The lunette fragments show Pay standing with his hands raised in adoration before Re-Horakhty (on the left-hand side). The legs of another deity adored by Pay are visible on the right-hand side.

The tomb of Ptahmose, Overseer of the King's Apartments, is lost. In view of the official's title of office, the tomb was likely situated in the same general area of the necropolis. This is where a number of "harem" officials were buried. Only the lower part of Ptahmose's stela is preserved. It contains nine lines of hieroglyphic text. At the bottom, Ptahmose and his mother, Ruy, are depicted kneeling in adoration. Their images face one another, and they are separated by seven columns of text.

Drawing together the information recorded on the stelae just listed, it is clear that both the texts and lunette decoration focus on the rising and the setting of the sun. It is likely, therefore, that the now-missing upper part of the stela of Ry also bore a double adoration scene. It would have depicted Ry standing with his hands raised in adoration before Atum and Re-Horakhty.

\section{[2] Entrance doorway, south reveal: In situ (Fig. 10)}

\section{Limestone}

H. $66 \mathrm{~cm}, \mathrm{~W} .47 \mathrm{~cm}$

Bibliography: Unpublished.

\section{Description}

Two joining fragments of a block carved in raised relief. Above the $32 \mathrm{~cm}$-high undecorated dado is the lowermost part of a scene depicting a lion-legged chair, possibly accommodating the tomb owner. The heel of the seated figure is visible atop the footrest on the left-hand side. Underneath the chair, a woman or young girl is shown seated on a low, round-legged and latticed stool with a seat cushion. ${ }^{34}$ She wears a plain dress, rests her left hand on her knee and raises her right hand, possibly to sniff a lotus flower. ${ }^{35}$ 


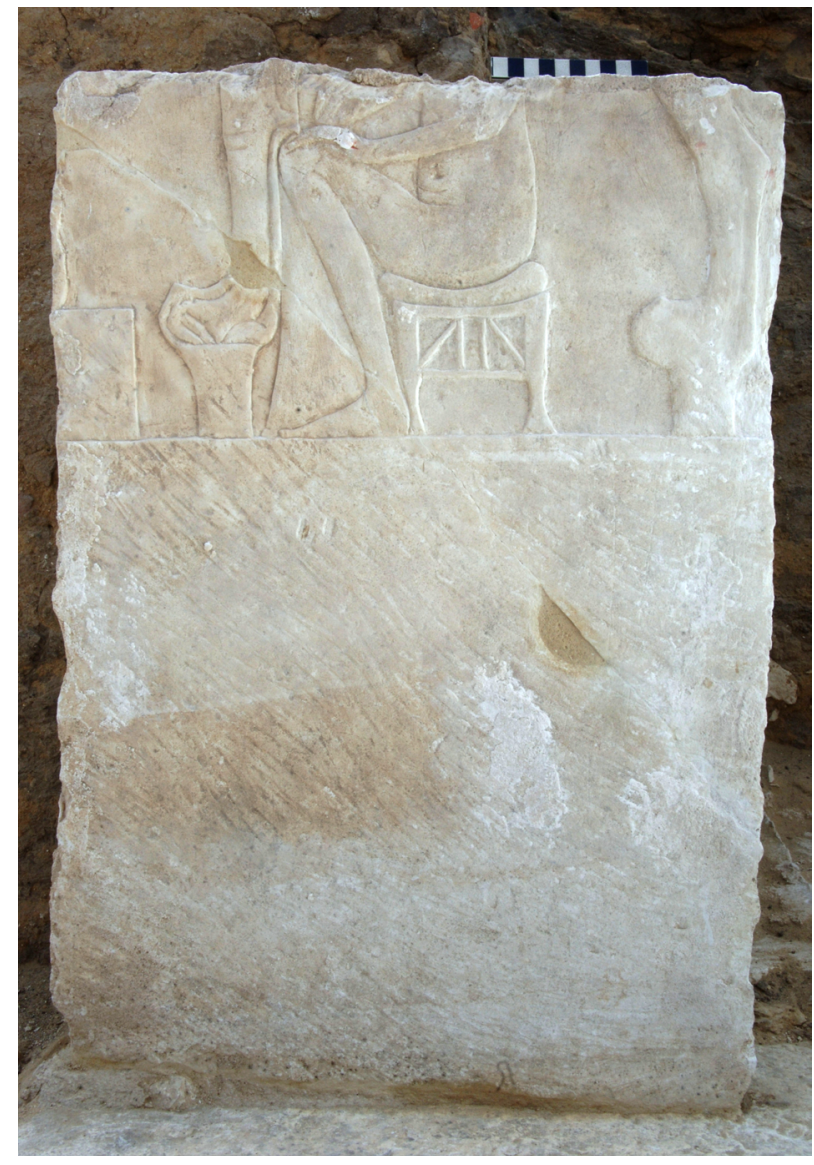

Fig. 10: Tomb of Ry, entrance doorway, south reveal: relief-decorated revetment block found in situ. Photo @Rijksmuseum van Oudheden/Anneke de Kemp.

\section{[3] Antechapel, south wall: Block Saqqara R94-78} (Figs. 11, 12)

\section{Limestone}

H. $110 \mathrm{~cm}$ (scene: $44.5 \mathrm{~cm}$ ), W. $95 \mathrm{~cm}$, Th. $13 \mathrm{~cm}$. Bibliography: Raven, Pay and Raia, 2005, pp. 47-48, scene [76], pls. 78, 82; Staring, Saqqara Newsletter 16 (2018), pp. 40-41, fig. 9; Staring, EgArch 54 (2019), fig. on p. 45.

\section{Description}

The antechapel south wall can be partially reconstructed from three joining fragments found by the EES/Leiden mission in 1994. The damaged block was recovered from the clean sand due east of the outer courtyard constructed by Raia (Fig. 12). We now know that the location where they were found corresponds to the southwest corner of the chapel of Ry. None of the recovered fragments bear traces of text, yet on account of the relief's style and iconography, the wall space available in the chapel, and the

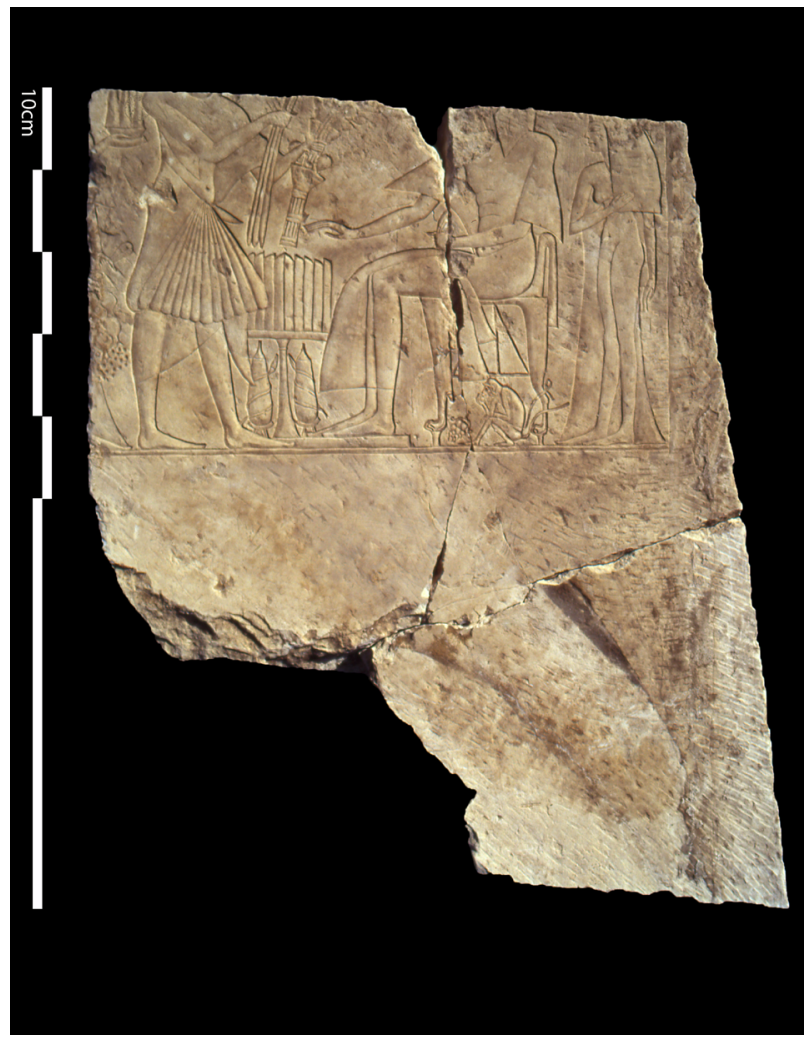

Fig. 11: Relief-decorated blocks R94-78. Photo ๑Rijksmuseum van Oudheden, Leiden, adapted by Nico Staring.

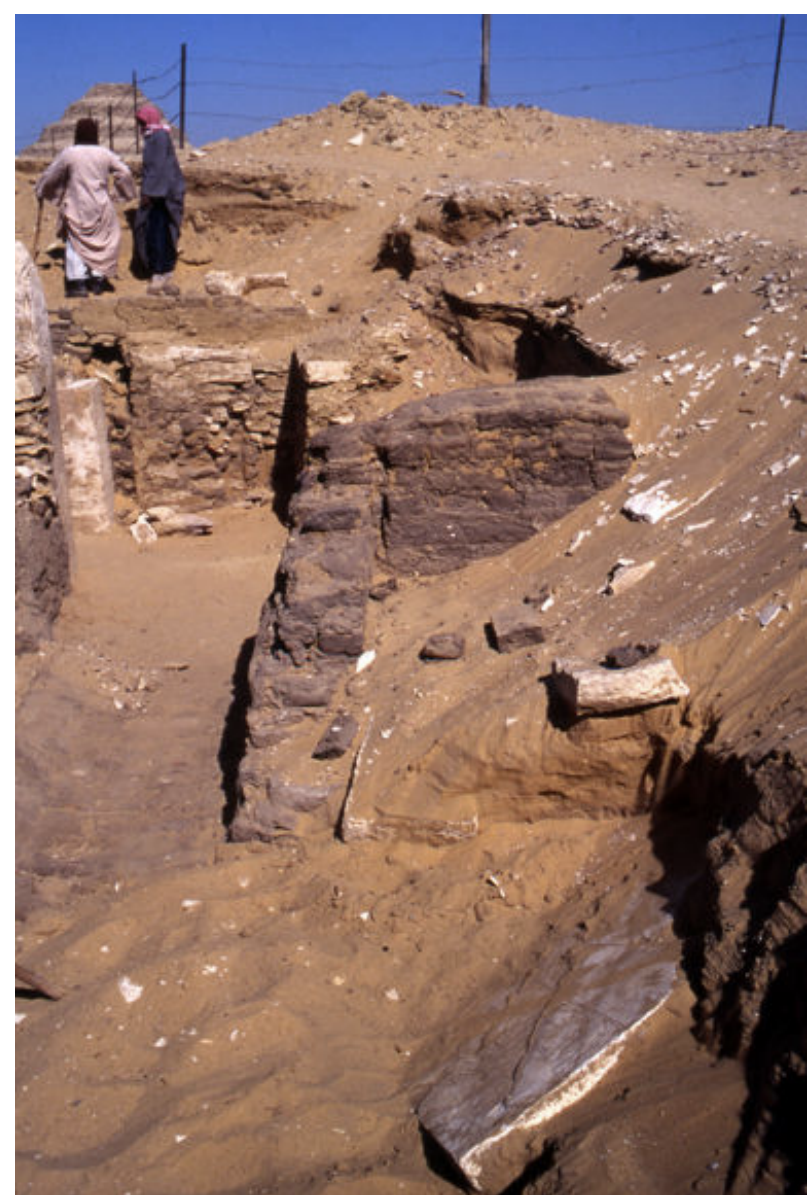

Fig. 12: Relief-decorated blocks R94-78 as found by the EES-Leiden expedition in the sand immediately south of the chapel of the tomb of Ry. The forecourt of Raia is to the left. Photo ${ }^{\odot R i j k s m u s e u m ~ v a n ~ O u d h e d e n, ~ L e i d e n . ~}$ 
find spot, there can be little doubt that the block derives from the tomb of Ry. The iconography mirrors the scene on the opposite north wall of the antechapel. Regarding the style, one could point to the garment worn by the offering bearer in scene [3]. It is of the same type worn by the officiant in scene [9] and by Ry in scene [7]. A line of plaster along the righthand edge of block R94-78 indicates that another slab once abutted it. That block must have depicted the striding tomb owner. One of his feet is visible on the head-end of scene [4], block Berlin ÄM 7277.

The scene is carved in sunk relief and centres on a couple in front of an offering table, facing left. The man is seated on a low-backed chair with a monkey depicted underneath. The woman stands behind the chair. She has her right arm folded over her chest. ${ }^{36}$ Two offering bearers approach the couple from the left. The male figure presents a bundle of three stalks of papyrus and a bouquet of flowers. The female offering-bearer brings various items: a bowl with three pointed loaves in one upheld hand, and a bunch of pomegranates and grapes in the other.

\section{[4] Antechapel, south end of west wall: Block Berlin} ÄM 7277 (Fig. 13a)

\section{Limestone}

H. $42.5 \mathrm{~cm}$, W. $11.5 \mathrm{~cm}$

Bibliography: Martin, Corpus of Reliefs, 1987, pp. 21-22, [43], pl. 16; Staring, Saqqara Newsletter 16 (2018), p. 37, fig. 6; Staring, EgArch 54 (2019), fig. on p. 43, bottom right.

\section{Description}

This is the head-end of scene [5]. It depicts the lower part of the front leg of a striding male, the tomb owner, facing right (north). He wears a long, plain garment and sandals. This scene mirrors that in [8].

[5] Inner sanctuary, south wall: Block Berlin ÄM $\mathbf{7 2 7 7}$ (Fig. 13b)

\section{Limestone}

H. $42.5 \mathrm{~cm}$, w. $110.5 \mathrm{~cm}$, Th. $12 \mathrm{~cm}$

Bibliography: Passalacqua, Catalogue raisonné, 1826, p. 73 [1406]; Martin, Corpus of Reliefs, 1987, pp. 21-22, [43], pl. 16; Staring, Saqqara Newslet-

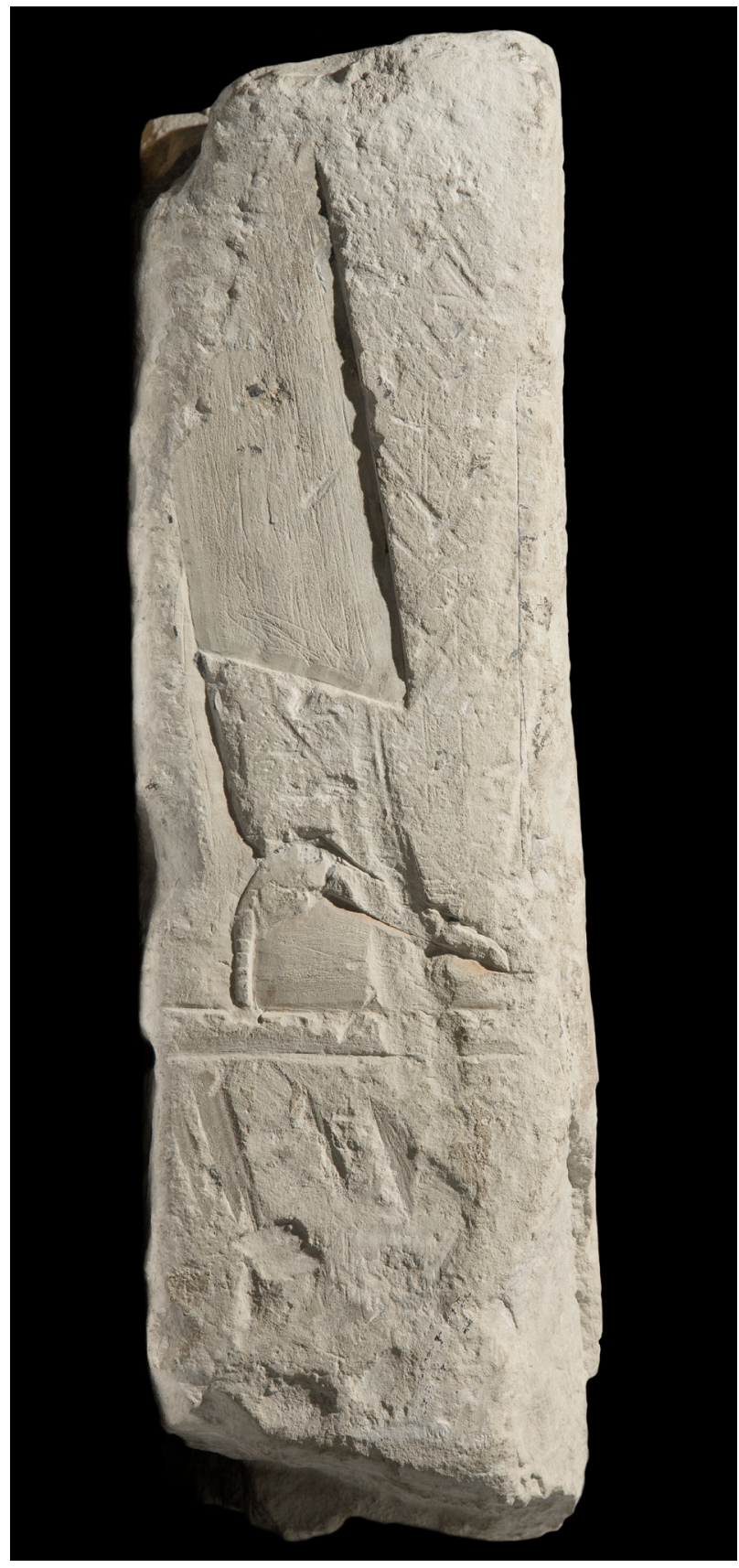

Fig. 13a: Tomb of Ry, inner sanctuary, south wall: reliefdecorated block Berlin, Ägyptisches Museum ÄM 7277. Photo ๑SMB Ägyptisches Museum und Papyrussammlung/ Sandra Steiß.

ter 16 (2018), figs. 5-6; Staring, EgArch 54 (2019), fig. on p. 43.

\section{Description}

The setting lines in the floor of the central chapel are indicative of the former presence of relief-decorated block Berlin ÄM 7277. ${ }^{37}$ The scene is carved in sunk relief. It is framed by a register line along the bottom and top edges. A vertically carved block frieze frames it along the left end. The scene depicts seven male 


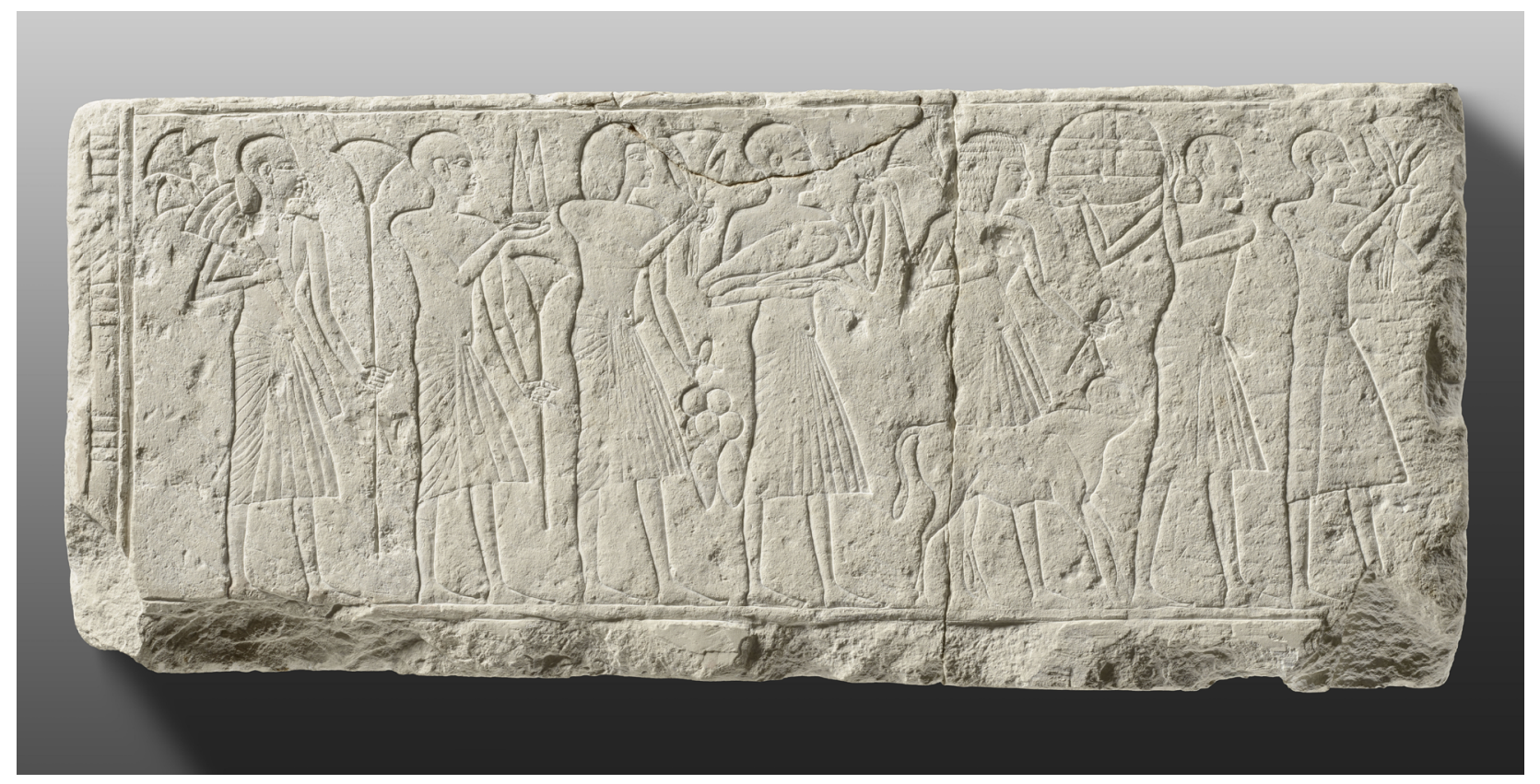

Fig. 13b: Tomb of Ry, inner sanctuary, south wall: relief-decorated block Berlin, Ägyptisches Museum ÄM 7277. Photo ๑SMB Ägyptisches Museum und Papyrussammlung/Sandra Steiß.

offering-bearers proceeding towards the right (west). Two men wear a wig, the others have shaved heads. One man cradles a crane and another leads a bull calf. Others bring flower bouquets and flowering papyrus stalks. The second offering bearer on the right supports with both hands a bowl on his right shoulder, filled with food offerings. ${ }^{38}$ Six offering bearers wear pleated sash kilts. The kilt of the man on the righthand side is plain. This scene mirrors that depicted on the chapel's north wall, scene [7].

\section{[6] Inner sanctuary, west wall: Stela Berlin ÄM 7290}

(Fig. 14)

\section{Limestone}

H. $157 \mathrm{~cm}$, W. $94.5 \mathrm{~cm}$, Th. $18 \mathrm{~cm}$

Bibliography: Erman, Ausführliches Verzeichnis, 1899, pp. 163-64; Roeder, Ägyptische Inschriften 2, 1924, pp. 182-84; Herzberg, in Kampp-Seyfried and Jung (eds.), China und Ägypten, 2017, pp. 198-99, fig. II.20; Staring, EgArch 54 (2019,) fig. on p. 45.

\section{Description}

The west wall of the inner sanctuary accommodated the stela cut from a single block of limestone, which is presently held in Berlin. The rectangular stela sits on a low base and is framed by a torus. The protruding lintel and jambs are inscribed with two

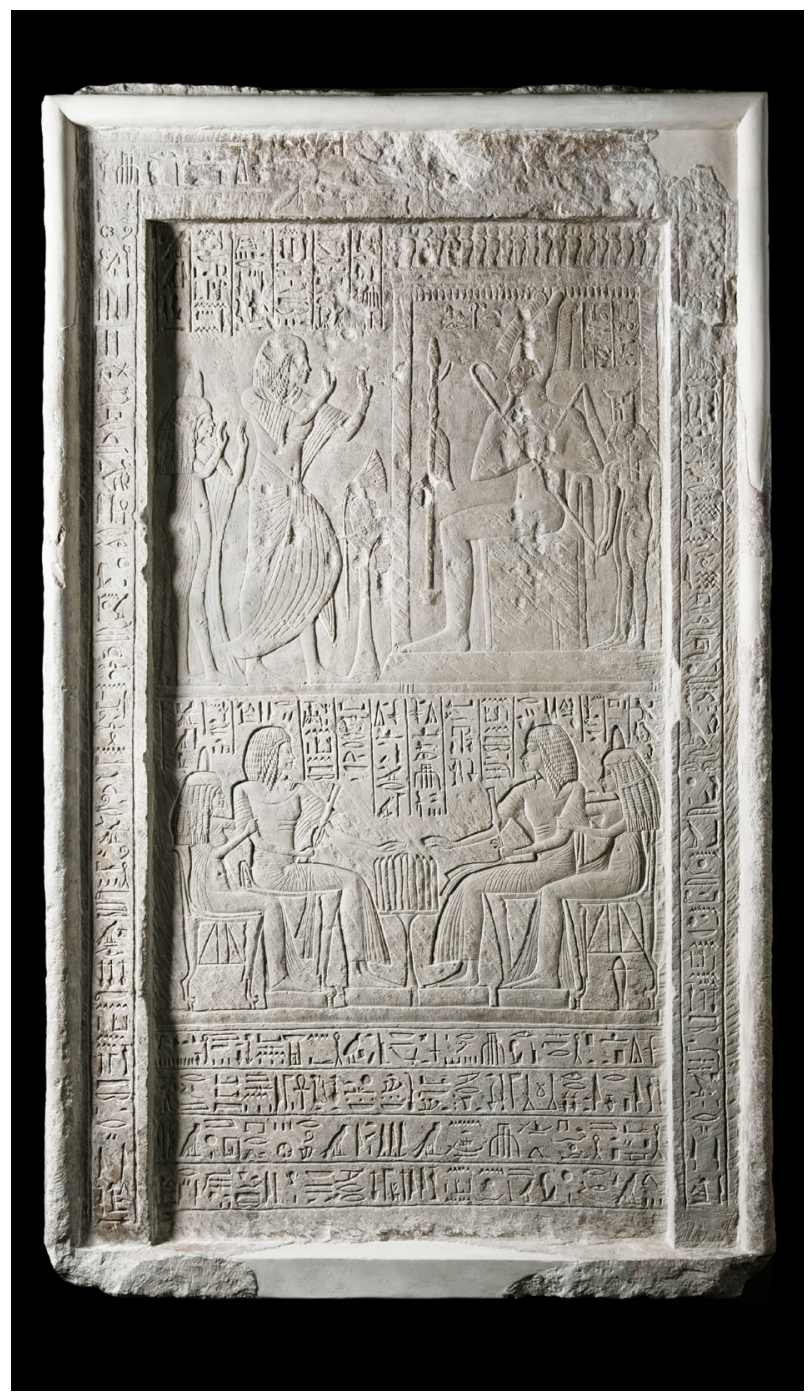

Fig. 14: Tomb of Ry, inner sanctuary, west wall: stela Berlin, Ägyptisches Museum ÄM 7290. Photo @SMB Ägyptisches Museum und Papyrussammlung/ Ingrid Geske. 
offering formulas set in framed lines and columns. In the centre, the lintel contains a mirrored image of the recumbent jackal god Anubis atop a shrine. Both images are adored by the kneeling couple Ry and Maia. The recessed central area of the stela is divided into three parts. They are two superimposed registers with scenes and a lower section comprising four lines of hieroglyphic text. The scene in the upper register is carved in raised relief, the one in the lower register in sunk relief. ${ }^{39}$

In the upper register, Ry and Maia are depicted standing, facing right, raising both hands in adoration before Osiris. Ry wears a layered wig and an elaborate garment consisting of a bag tunic and pointed apron. The pleated, wrap-around sash kilt is executed in a peculiar manner, shaped in a semi-circle pointed backwards. ${ }^{40}$ Ry wears the two-row shebyu collar, the Gold of Honour, around his neck. ${ }^{41}$ Maia is depicted as much shorter than her husband. The top of her head is level with Ry's shoulders. She wears an ankle-length pleated dress and a perfume cone atop her elaborately braided wig. A short inscription in six framed columns is incised above the couple.

Osiris, accompanied by his imiut symbol, is depicted seated on a low-backed throne under a canopy. The latter is lined along the top with cobras supporting sun disks. The mummiform god wears the atef crown and holds his distinctive regalia. ${ }^{42}$ The goddesses Isis and Nephthys are standing behind (or rather, beside) Osiris. The signs for their names are situated atop their heads. Short framed and unframed texts in raised relief identify the three gods by name.

The deceased couple and Osiris are separated by an offering stand supporting a nemset jar and lotus flower oriented towards the god.

The scene in the lower register is exceptional. ${ }^{43}$ It shows a mirrored representation of the deceased couple Ry and Maia sitting vis-à-vis at a single offering table covered with slices of bread. They are unaccompanied by offering bearers - at least as far as the stela is concerned. The stela decoration should clearly be viewed in the broader context of the chapel's decorative programme. The bearers bringing the offerings to the seated couples are depicted not on the stela, but on the abutting north and south walls of the inner chapel.

The deceased couple are seated on lion-legged

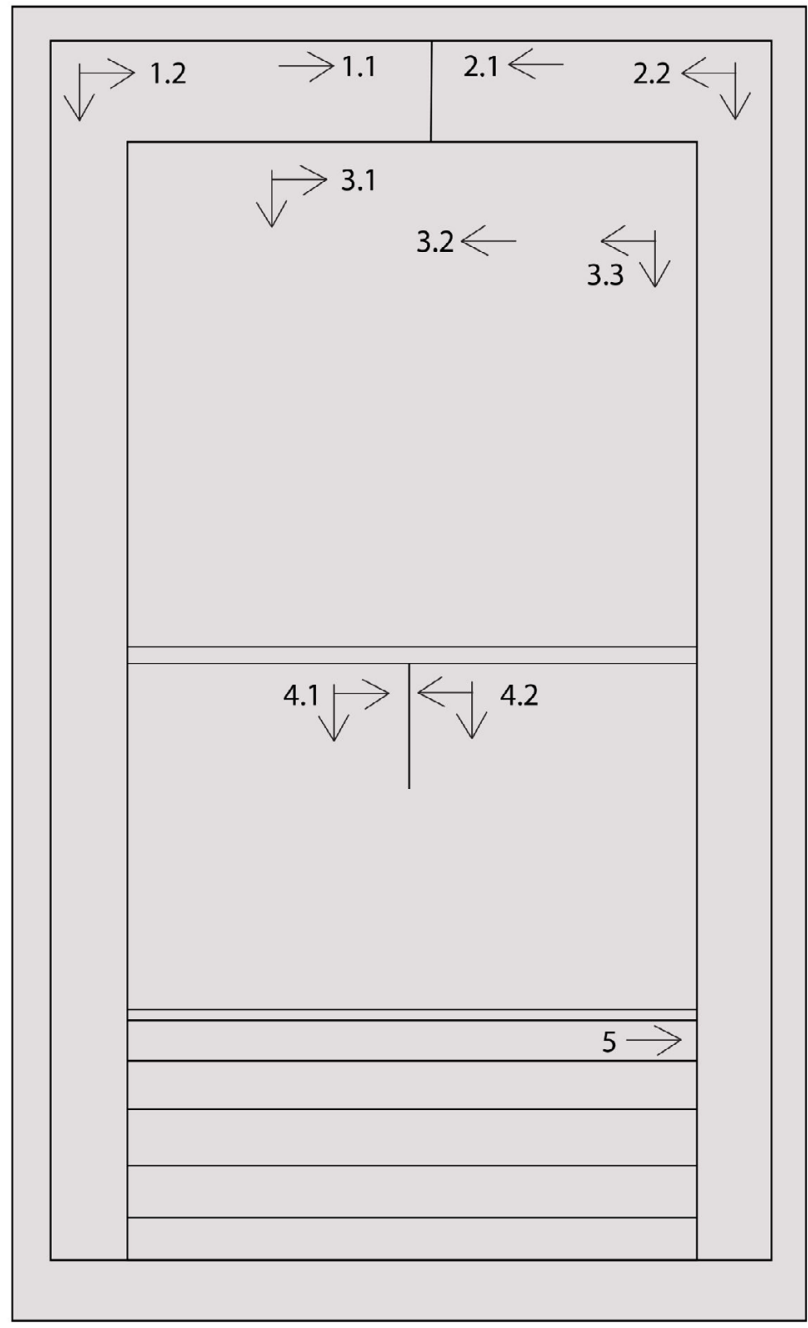

Fig. 15: Stela Berlin ÄM 7290: distribution of texts.

chairs and their feet are positioned on foot rests. Underneath Maia's chair in the right-hand image is an oil jar. Ry and Maia wear elaborate, long garments. Perfume cones are positioned atop Maia's wig. In the left-hand image, Ry holds a short sekhem sceptre in combination with a "lettuce" sceptre and folded napkin in his right hand. He extends his left hand over the offering table. In the right-hand image, it is his right hand which he extends over the offering table. The sekhem sceptre and folded napkin are held in his left hand. Note that in the left image the cloth is represented in front view (hanging down straight), and in the right image it is represented in side view (hanging down over the knees).$^{44}$ In both scenes, Maia embraces her husband. Each image of the deceased couple carries an offering formula set in framed columns.

The lower part of the stela contains four lines of incised hieroglyphs, encompassing one elaborate offering formula. 
Translation of the texts

$(\rightarrow)$ [1.1] Anubis [who is in the place of embalming] (and) who is on [his] mountain.

$(\rightarrow)$ [1.2] An offering which the king gives to Osiris, Foremost of the West, Lord of Busiris, Sovereign, King of Gods of the Underworld, may he grant that (I) may go out as a living ba to see the sun when it rises in the horizon, that (I) may not be warded off or held back, to see your body at the sight of your beauty, for the $k a$ of the one praised by the Perfect God (i.e. the king), Chief of Bowmen, Ry, true of voice.

$(\leftarrow)$ [2.1] [No legible traces of hieroglyphic inscription preserved.]

$(\leftarrow)$ [2.2] [An offering which the king gives to ? and Re-] $(\leftarrow \downarrow)$ Hor[-akhty], Lord of ///, may they grant a sweet breeze of the north wind, that (I) may drink water from the river, that (I) may go forth by day as a Follower of Horus to see Re as he rises every day, for the $k a$ of the one praised by the Perfect God (i.e. the king), the Chief of Bowmen, Overseer of Horses, Ry, true of voice.

$(\downarrow \rightarrow)$ [3.1] ${ }^{\mathbf{1}}$ Adoring Osiris, Foremost of the West, [Great] God, ${ }^{2}$ Lord of the Sacred Land, may he grant entering [and leaving] the necropolis ${ }^{\mathbf{3}}$ [for] the one praised by the Perfect God, True $<$ Scribe $>$ whom he loves, Chief of Bowmen, ${ }^{4}$ Overseer of Horses, Ry, true of voice, ${ }^{\mathbf{5}}$ (and) his sister (i.e. wife), Lady of the House, Songstress of Amun, Maia, ${ }^{\mathbf{6}}$ true of voice.

$(\leftarrow)[3.2]^{\mathbf{1}}$ Osiris Ruler of Eternity. ${ }^{\mathbf{2}}$ Isis the Great, mother of the god. ${ }^{\mathbf{3}}$ Nephthys who resides in the west. $(\downarrow \rightarrow)[4.1]^{\mathbf{1}}$ An offering which the king gives to Isis the Great, mother of the god, ${ }^{2}$ may she grant all that comes forth ${ }^{3}$ upon the offering table for the $k a$ of the Chief of Bowmen, ${ }^{4}(\rightarrow)$ Ry, ${ }^{\mathbf{5}}$ (and) his sister (i.e. wife), the Lady of the House, ${ }^{\mathbf{5}}$ Maia.

$(\leftarrow \downarrow)[4.2]^{1}$ An offering which the king gives to Osiris, Foremost of the West, ${ }^{2}$ may he grant an invocation offering of bread, beer, incense and libation ${ }^{3}$ for the $k a$ of the Chief of Bowmen, Overseer of Horses, ${ }^{4}(\leftarrow)$ Ry, ${ }^{\mathbf{5}}$ and his sister (i.e. wife), the Lady of the ${ }^{6}$ House, Maia.

$(\rightarrow)[5]^{\mathbf{1}}$ An offering which the king gives to PtahSokar-Osiris, Foremost of Rosetau, who is in the Place of Embalming, Lord of the Necropolis, it is Isis together with Nephthys, may they grant 1000 of bread, beer, oxen, fowl, ${ }^{2}$ libation, wine, milk, alabaster, linen, incense, ointment, all fresh (plant-)offers, and all good and pure things from which a god lives, that which the sky gives, that which ${ }^{\mathbf{3}}$ the Nile brings forth from its source, sailing upstream and downstream in the Field of Rushes, going forth by day as a follower ${ }^{4}$ of Horus in order to see Re as he rises, for the $k a$ of the one praised by the Perfect God (i.e. the king), one loved by the Lord of the Two Lands on account of his character, the Chief of Bowmen, Overseer of Horses, Ry.

\section{[7] Inner sanctuary, north wall: In situ + Block Berlin ÄM $\mathbf{7 2 7 5}$ (Fig. 16)}

\section{Limestone}

In situ: H. 73 cm, W. 16.5 cm; ÄM 7275: H. 132 cm, W. $92 \mathrm{~cm}$, Th. $13.5 \mathrm{~cm}$.

Bibliography: Passalacqua, Catalogue raisonné, 1826, pp. 55-56, 73 [1378]; Roeder, Ägyptische Inschriften 2, 1924, p. 198; Fründt, FuB 3/2 (1961), fig. 2; Hofmann, Bilder im Wandel, 2004, fig. 120; Staring, EgArch 54 (2019), fig. on p. 44.

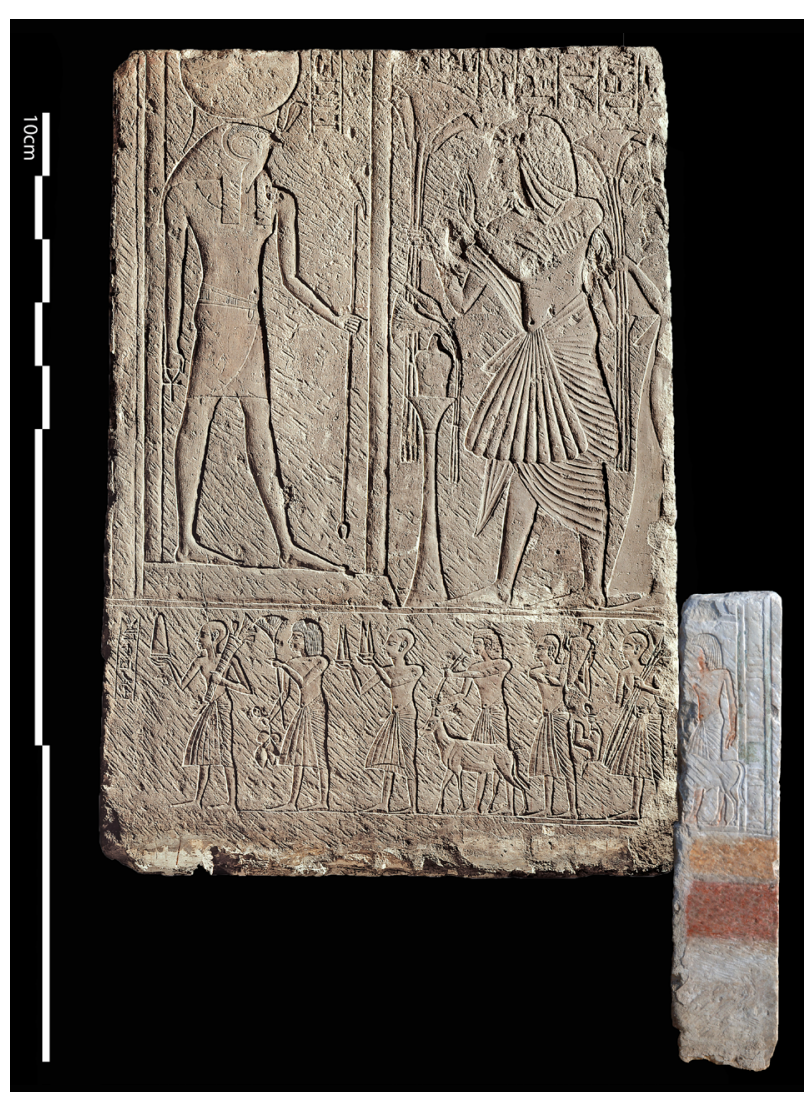

Fig. 16: Tomb of Ry, inner sanctuary, north wall: reliefdecorated block Berlin, Ägyptisches Museum ÄM 7275 and revetment block found in situ. Photos @SMB Ägyptisches Museum und Papyrussammlung/Jürgen Liepe; Rijksmuseum van Oudheden, Leiden/Anneke de Kemp. Digitally joined by Nico Staring. 


\section{Description}

The block found in situ is the head-end of block [8] It preserves traces of scenes in two superimposed registers, carved in sunk relief. The left end joins block Berlin ÄM 7275. The two blocks account for the total width of the wall, measuring $127 \mathrm{~cm}$. The block in situ preserves traces of colour, whereas all traces of colour have vanished from the Berlin block. A band of yellow and red colours decorate the dado. The horizontal red band is situated at the same level as the one on the antechapel walls.

The upper register depicts the deceased couple Ry and Maia standing before the god Re-Horakhty. Both raise one hand in adoration (Ry, left hand; Maia, right hand), and hold three papyrus stalks in the other. Ry wears a plain, layered wig and an elaborate garment consisting of a bag tunic and a pleated wrap-around sash kilt goffered in front. ${ }^{45}$ It is worn in combination with a pointed apron. Over his tunic, Ry wears a plain collar and a two-row shebyu, or Gold of Honour. Only half of Maia's posture is preserved on the Berlin block. The lower end of her dress is just visible on the block found in situ. It is not clear what type of wig she is wearing. Only a lotus flower with a closed bud is visible hanging down on her forehead. Her plain dress reaches to the ankles and the contour lines of her body are visible underneath. The carved remains of seven framed columns of hieroglyphic text are situated above the couple's heads. Re-Horakhty is represented in his falcon-headed anthropomorphic form. A sun disk encircled by a cobra is placed atop his head. In his left hand he clasps a was sceptre and in his right hand he holds an ankh sign. The god stands under a canopy. The latter structure is placed on a raised pedestal shaped as the hieroglyph for maat. A single framed column of text identifies the god. An offering stand supporting a nemset jar separates Re-Horakhty and the deceased couple. Two lotus flowers, one with a closed, the other with an open bud, are laid across the jar, facing towards the god. The lower register depicts seven male offering bearers, facing left. All wear sash kilts, and some wear wigs while others' heads are shaved. They bring forth assorted items, including live animals - a bull calf and a gazelle -, fowl, a vessel, dishes with bread, papyrus, and lotus stalks, and a bouquet of flowers. A framed column of hieroglyphic text identifies the

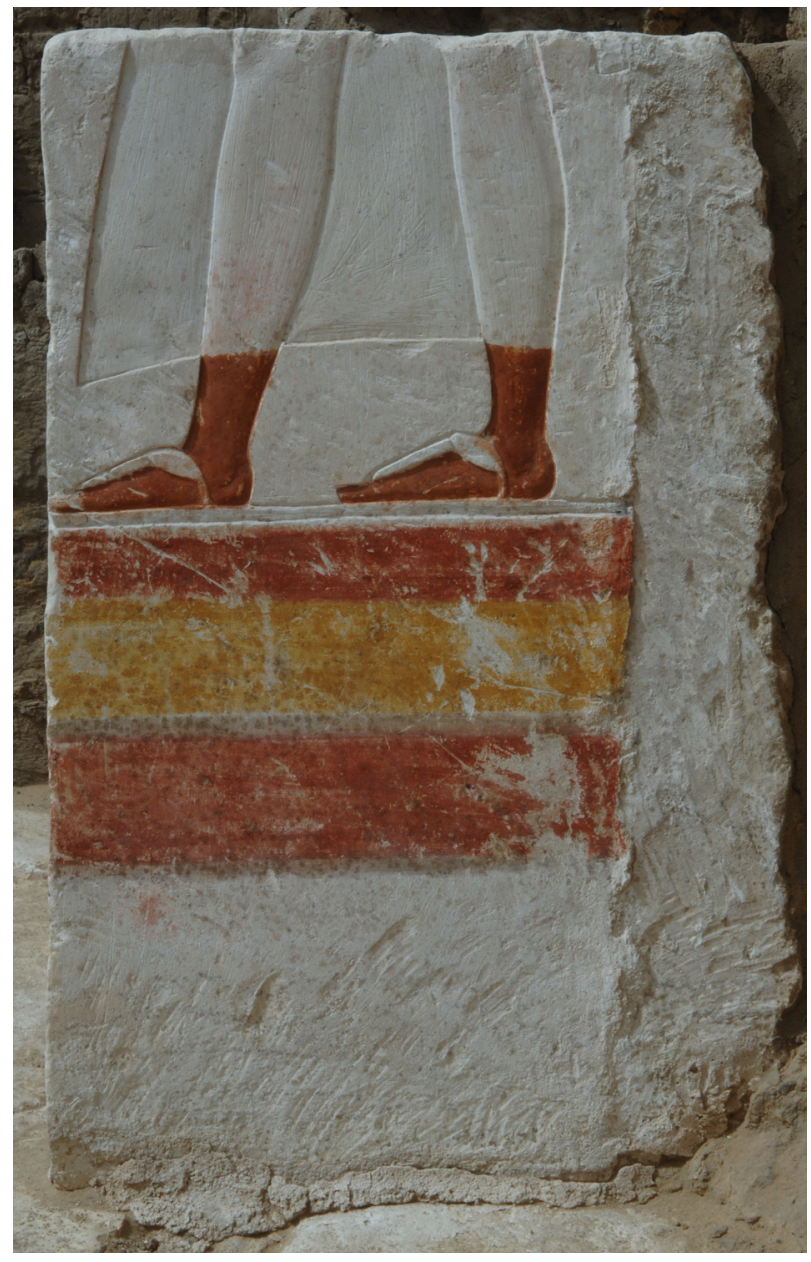

Fig. 17: Tomb of Ry, antechapel, west wall, north part: relief-decorated revetment block found in situ. Photo ๑Rijksmuseum van Oudheden, Leiden/Anneke de Kemp.

offering bearer leading the group as the servant ( $\mathrm{s} d \mathrm{~m}$ `) Ka. The register line under the scene is unfinished.

\section{Translation of the texts}

In front of Re-Horakhty:

[Re-Horakhty], Great God, Lord of the Sky.

Above Ry and Maia:

${ }^{1} / / /$ created ${ }^{2} / / /$ ? ? ${ }^{3} / / /$ the Heliopolitan, adoring ${ }^{4}$ your appearances?? ${ }^{\mathbf{5}} / / /$ you go to rest in ${ }^{6} / / /$ ?? $^{7}[\mathrm{R}] \mathrm{y}$

The leading offering bearer:

The servant $\mathrm{Ka}$

\section{[8] Antechapel, west wall, north part: In situ (Fig. 17)}

\section{Limestone}

H. $76 \mathrm{~cm}$, W. $48 \mathrm{~cm}$.

Bibliography: Raven, Saqqara Newsletter 11 (2013),

figs. 5-6. 
Block depicting the lower part of a man, the tomb owner, facing left (south). He wears a plain garment and sandals. A horizontal band coloured red-yellow-red runs below the scene, carrying over from the abutting antechapel north wall. This scene mirrors scene [4].

[9] Antechapel, north wall: In situ + blocks Berlin ÄM $\mathbf{7 2 7 8}+$ fragment SAK 2013-R35 (Figs. 18, 19)

\section{Limestone}

In situ: H. 94 cm, W. 31.5; ÄM 7278, right block: H. $89.5 \mathrm{~cm}$, W. $86 \mathrm{~cm}$, Th. $14.5 \mathrm{~cm}$; ÄM 7278, left block: H. $96.7 \mathrm{~cm}$, W. $80.5 \mathrm{~cm}$, Th. $14.5 \mathrm{~cm}$; + fragment SAK 2013-R35: H. 25.5 cm, W. $17.3 \mathrm{~cm}$; Th. $11 \mathrm{~cm}$

Bibliography: Passalacqua, Catalogue raisonné, 1826, p. 72-73 [1405]; Roeder, Ägyptische Inschriften 2, 1924, p. 181; Fründt, FuB 3/2 (1961), fig. 1; Martin, Corpus of Reliefs, 1987, pp. 20-21 [42], pl. 15, front and back cover; Martin, Hidden Tombs, 1991, fig. 122; Raven et al., JEOL 44 (2012-13), p. 44, fig. 8 (left); Staring, Saqqara Newsletter 16 (2018), fig. 8; Staring, EgArch 54 (2019), fig. on p. 44.

\section{Description}

A single relief-decorated revetment block was found in situ, positioned perpendicular to the block bearing scene [10]. On the left-hand side it joins Berlin ÄM $7278 .{ }^{46}$ A small relief-decorated fragment found during excavation (reused in the dry-stone wall built around the tomb shaft, possibly in conjunction with the early exploration of the tomb in the 1820s) joins the Berlin block on the upper left-hand side. The joined blocks account for the full width of this wall, measuring $198 \mathrm{~cm}$. The single scene is carved in sunk relief and preserves ample traces of colour. The wall surface between the scene and the undecorated dado bears a horizontal band of alternating colours, red-yellow-red. The joining Berlin blocks preserve only part of this decorative band. It stands to reason that at some point in time after their removal from the tomb wall excess stone was sawn off from the blocks' lower edge.

The scene is bordered along the lower edge by a register line and on the right and left-hand edges by a vertical block frieze. It depicts an offering and puri- fication scene centred around the tomb owner and his wife. A group of five individuals approach the seated couple Ry and Maia from the right. The scene is a continuation of that featuring offering bearers depicted on the adjacent east wall, although the latter are shown on a slightly smaller scale. The group of five individuals on the north wall is composed of two female and one male offering bearer and two male officiants. The anonymous offering bearers bring food offerings including a pintail duck and a bull calf, papyrus stalks, and a bouquet of flowers. Standing in front of them is the male officiant, a man with a shaved head, clad in a sash kilt and wearing a leopard skin over his shoulder and hanging down his back. He is acting as a priest. In his two upraised hands he holds a nemset jar from which he pours a libation of water. The water is represented by two wavy lines that extend over Ry and Maia. ${ }^{47}$ A single column of framed hieroglyphs identifies this man as the servant $(s \underline{d} m-\ulcorner\breve{s})$ Ahanefer. The man standing in front of the well-stacked offering table is dressed in an elaborate garment, consisting of a bag tunic with outward flaring pleated "sleeves" and a pleated wrap-around sash kilt goffered in front. ${ }^{48}$ In his raised left hand he holds a long-armed censer in which incense is burning, in his raised right hand a nemset jar with a spout from which he pours a libation of water. A short hieroglyphic text set in a framed column identifies him as the stablemaster (hr.y ih.w), Maia.

The recipients of the offerings and libations, Ry and Maia, are identified by their names and titles. The couple are seated on two distinct lion-legged chairs. A leashed monkey stands below (or rather, beside) Maia's chair. The couple rest their feet on low footrests. Ry wears a composite garment, consisting of a bag tunic with outward flaring ample pleated "sleeves" and a "skirt" reaching to the ankles, in combination with a wrap-around sash kilt tied in front. The short end of the tied sash kilt is represented as a short "apron" with fringed ends. Over his tunic, Ry wears a broad collar, and a perfume cone is positioned atop his duplex wig. He extends his raised left arm towards the offering table and in his right hand he holds a folded cloth and sekhem sceptre. Maia wears an ankle-length pleated robe knotted below her breasts, over which she wears a broad collar. A lotus 


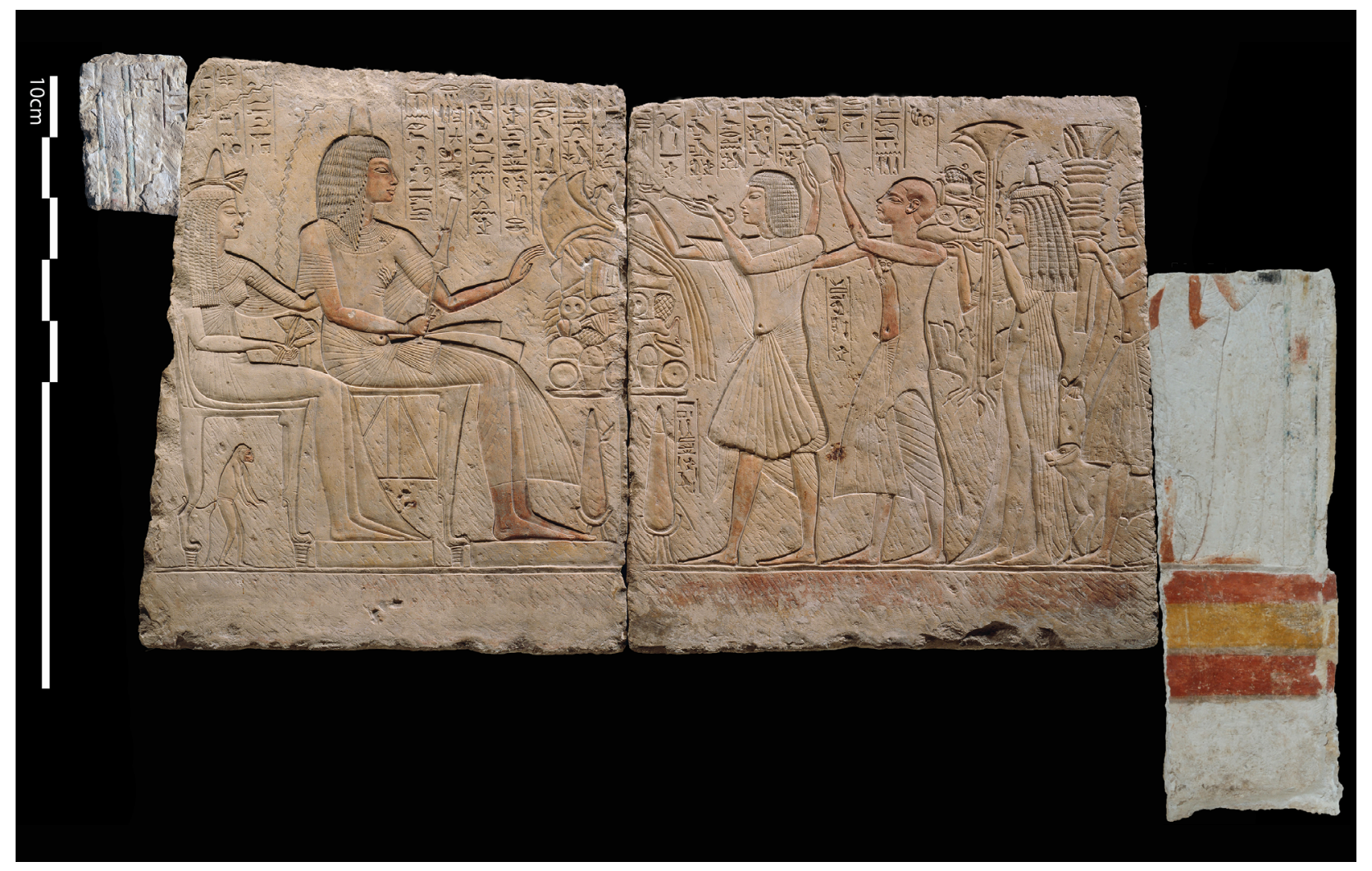

Fig. 18: Tomb of Ry, antechapel, north wall: relief-decorated block Berlin, Ägyptisches Museum ÄM 7278, fragment SAK 2013-R35, and revetment block found in situ. Photos $\odot$ SMB Ägyptisches Museum und Papyrussammlung/Jürgen Liepe; Rijksmuseum van Oudheden, Leiden/Anneke de Kemp. Digitally joined by Nico Staring.

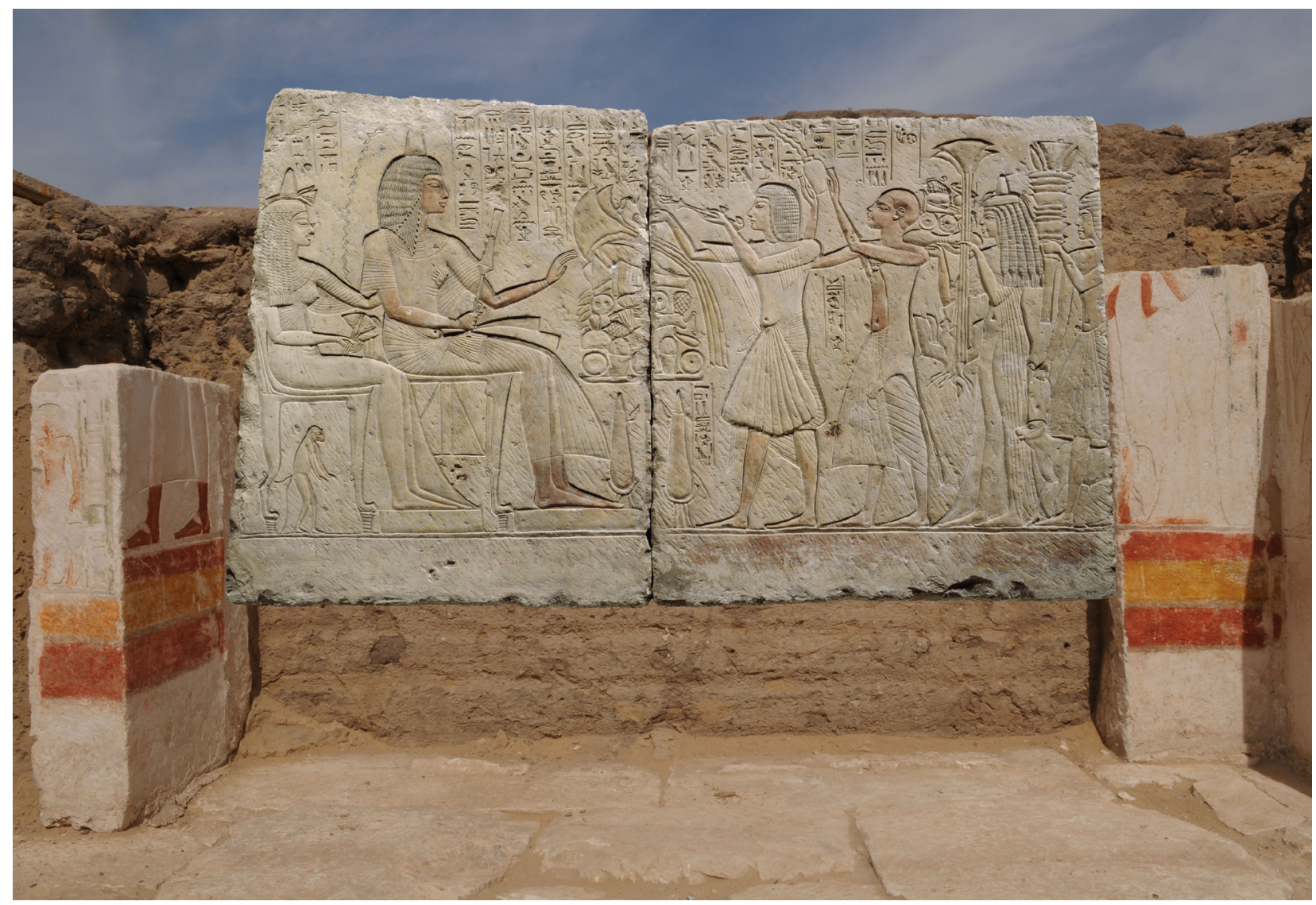

Fig. 19: Tomb of Ry, antechapel, north wall: relief-decorated block Berlin, Ägyptisches Museum ÄM 7278, recontextualised. Photos, respectively, ๑SMB Ägyptisches Museum und Papyrussammlung/Jürgen Liepe and ๑Rijksmuseum van Oudheden, Leiden/ Anneke de Kemp. Digitally joined by Nico Staring. 
flower and perfume cone are positioned atop her elaborately braided wig. She embraces her husband with her left arm and her hand reappears on Ry's chest. In her right hand she holds four lotus flowers, two with open, the other two with closed buds. ${ }^{49}$

A hieroglyphic text carved in seventeen framed columns is set above the offering table scene, starting in front of Ry's face and extending all the way to the second officiant facing him. The wavy lines of water poured from the nemset jar cut through the text. From column 3 onwards, the text can be identified as an excerpted version of BD spell $1491 .{ }^{50}$ In view of the fact that not a single occurrence of this BD text has been identified in the wall decoration of a tomb in the Memphite necropolis so far, and in order to offer a possible explanation for the text's relationship to the offering and purification scene, this text will be treated here in more detail.

\section{Text and translation}

Over Maia:

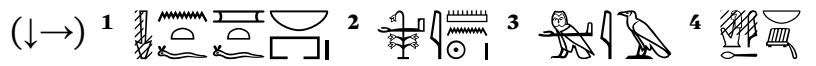
$5 \stackrel{\theta}{\circ}$

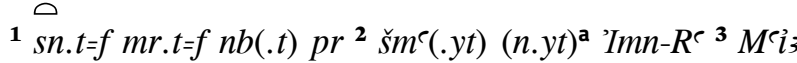
${ }^{4} m_{3}{ }^{<}<. t>-h r w n b<. t>i m 3 h^{\mathbf{5}} h t p^{\mathrm{b}}$

${ }^{1}$ His sister (i.e. wife) whom he loves, Lady of the House (and) ${ }^{\mathbf{2}}$ Songstress of Amun-Re, ${ }^{\mathbf{3}}$ Maia, ${ }^{\mathbf{4}}$ Lady of reverence ${ }^{\mathbf{5}}$, in peace.

In front of Ry:

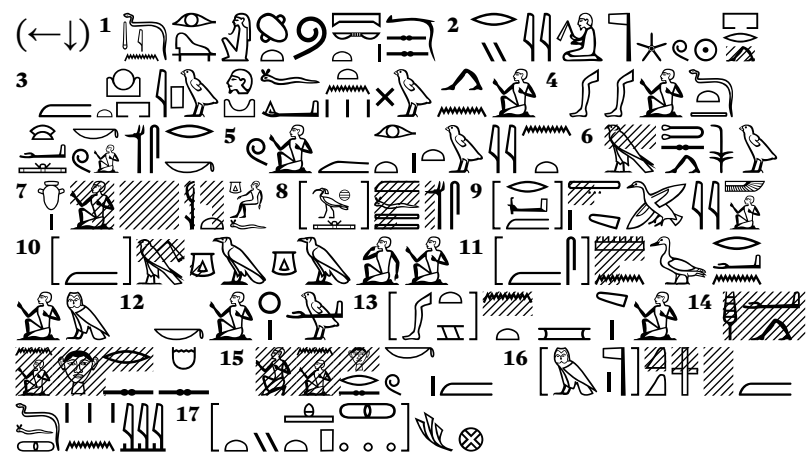

${ }^{1} \underline{d} d m d w$ in Wsir wt.w hr.y-pd.t im.y-r3 ss $[m . w t]^{\mathbf{2}} R y^{\mathrm{d}}$ $n t r-d w z y^{\mathbf{e}} p r . w^{\mathbf{3}} m$ 3h.t' $I<n>p w$ tp.y $\underline{d} w=f d i=t n$ swz. $n=i$ ${ }^{4} r d . w y=i<n=i>d . t^{f} h{ }^{c} . k w$ wsr. $k^{-5}-w m$ ir.t twy $n .(y) t$

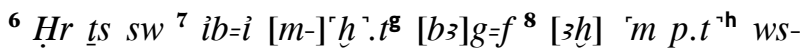

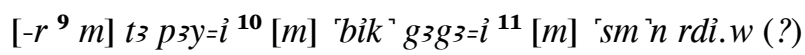

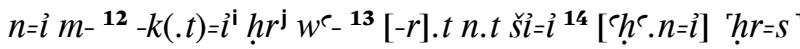
$h m s^{15}[-. n=i] h r=s<h r>^{k} . k w m^{16}[n t r] \quad w n m=i^{-1} m$ df $3 . w n$ sh.t ${ }^{\mathbf{1 7}}$ htp. ${ }^{\mathbf{m}}$
${ }^{1}$ Words spoken by the Osiris, the Embalmed One, Chief of Bowmen and Overseer of Horses, ${ }^{2}$ Ry: "O Morning Star, who emerges ${ }^{3}$ from the horizon, (and) Anubis who is on his mountain, may you grant that I walk, ${ }^{4}$ my legs being mine forever, while I rise and am powerful ${ }^{\mathbf{5}}$ because of this Eye of ${ }^{6}$ Horus who raises ${ }^{7}$ my heart after it had weakened, ${ }^{\mathbf{8}}$ being a spirit-state in heaven and powerful ${ }^{\mathbf{9}}$ on earth. I fly up ${ }^{\mathbf{1 0}}$ as a falcon and I cackle ${ }^{\mathbf{1 1}}$ as a goose, to me has been given ${ }^{\mathbf{1 2}}$ my place in the district ${ }^{\mathbf{1 3}}$ of $\{$ my lake. ${ }^{14}$ I stand on it and I sit ${ }^{\mathbf{1 5}}$ on it, while appearing as a god. ${ }^{\mathbf{1 6}} \mathrm{I}$ eat of the food of the Field ${ }^{\mathbf{1 7}}$ of Offerings. ${ }^{51}$

Officiant 1:

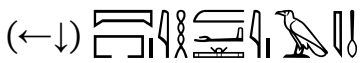

hr.y ih.w Mriz mз'-hrw

The Stablemaster, Maia, true of voice.

Officiant 2:

$(\leftarrow \downarrow) \bullet \subsetneq$ 是賭通

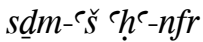

The Servant, Ahanefer.

Notes on text and translation

a The genitive adjective $n$ appears to be graphically represented by the wavy line of water that cuts through the text.

b One would expect the phrase to be written as imsh $m$ htp. However, these is no space available above the word $h t p$, because the top of the column divider is clearly visible. The inscription of scene [12] (Jerusalem, Studium Biblicum Franciscanum Museum, inv. no. CTS-SB-06202) also omits the sign for $m$ in $n b$ imsh htp.

' I am not aware of any parallel, in this context, for the use of the expression.

d The element $y$ appears to be written with three strokes. However, the third "stroke" is more probably the result of damage which by accident looks like a stroke. I am not aware of a writing of the name with three strokes.

e See BD 13=121 and 122b.

f In a number of BD manuscripts it reads $r d . w y=\hat{\imath} n=\hat{l}$ d.t. "my legs are mine for ever". The author of the text in the tomb of Ry made changes to this passage so as to connect it to the verb $s w 3$, "to walk", "pass", which does not occur in the MS texts. ${ }^{52}$ 
g Parallels suggest the presence of $m$-h.t. I do not know how to interpret the square-shaped traces below $i b=i$. The square-shaped traces actually appear to be cut too deep to be part of the original hieroglyphic inscription, which suggests that the traces were introduced at a later stage, perhaps even after the slab's removal from the tomb. ${ }^{53}$

${ }^{\mathrm{h}}$ The reading of column 8 is problematic. Parallels have appear to accommodate such as reading. However, I have no alternative reading based on these traces.

' Wb II, p. 161. This reading implies that the wavy lines of water poured from the nemset jar cutting through the text leave no space for additional signs at the top of the column. At this point, the MS texts have $\prod_{\text {, }}^{\ominus}$, shn, "to rest/settle" (var. $\operatorname{shn} n=i, r d i(w)$ $n=i \operatorname{shn}, q r \operatorname{ir}(w) n=i \grave{s h n})$.

' This should be read as .

ז $\simeq$ for $\square$.

I The signs for $h^{c}$ are missing here, unless carved as (without the hand in the ayin). If the latter option is accepted, there would be very little space for the sign-group $h r=s$ in the now-missing upper part of the column.

m The MS texts have $\Delta$ 具, $k k$, a synonym for wnm, "to eat", from which it is derived (used since the Eighteenth Dynasty, see Wb V, p. 71). The visible signs allow for the identification of the sign for wnm (Gardiner sign-list Z11), the interpretation of the traces to the left and right is tentative.

${ }^{n}$ Alternatively reconstructed as sh.t ỉrr.w, although less frequently so in papyrus manuscripts.

\section{[10] Antechapel, east wall, north part: In situ (Fig. 20)}

\section{Limestone.}

H. $92 \mathrm{~cm}$, W. $53.5 \mathrm{~cm}$.

Bibliography: Raven et al., JEOL 44 (2012-13), fig. 8 (right); Staring, Saqqara Newsletter 16 (2018), p. 38, fig. 7; Staring, EgArch 54 (2019), fig. on p. 43.

\section{Description}

This block preserves a scene carved in sunk relief, bearing no trace of colour. It features three male offering bearers facing left. All men wear sash kilts and have shaved heads. One of their distinctive features is the fold on the nape of their necks. ${ }^{54}$

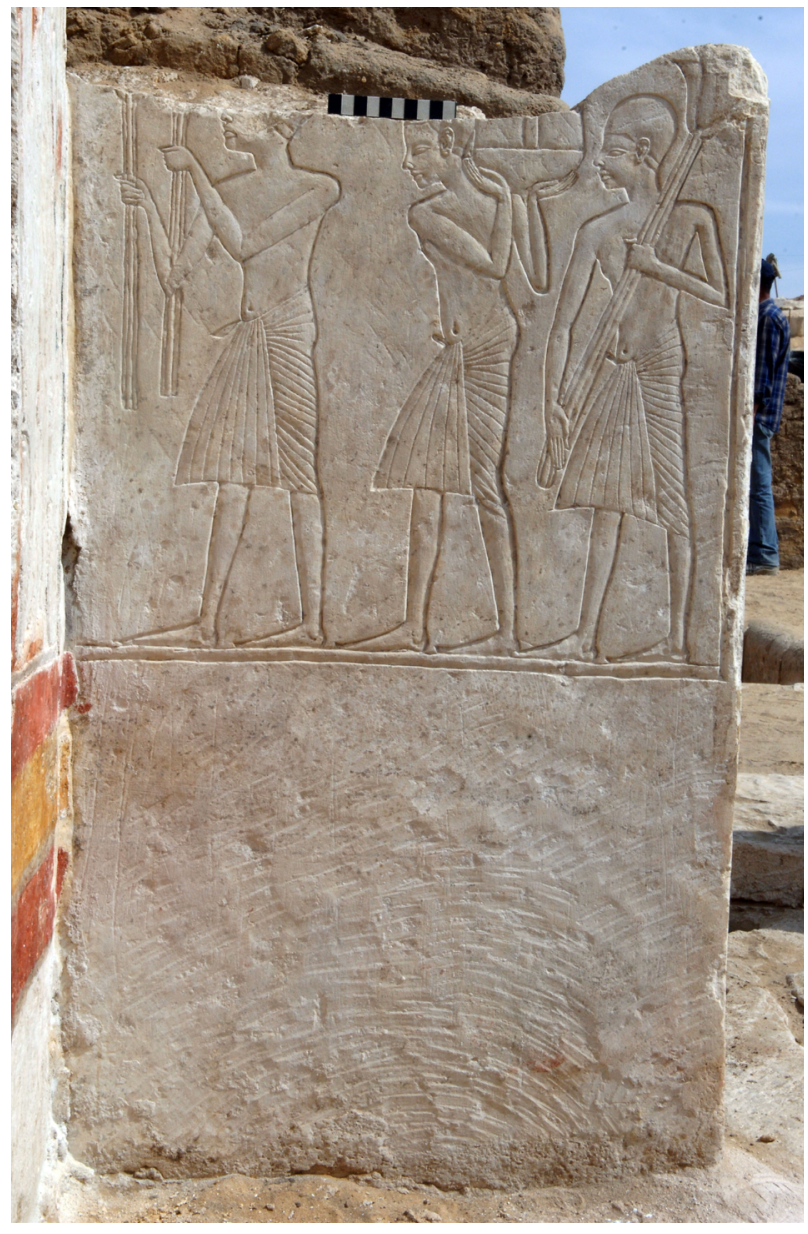

Fig. 20: Tomb of Ry, antechapel, east wall, north part: reliefdecorated block found in situ. Photo @Rijksmuseum van Oudheden, Leiden/Anneke de Kemp.

The central offering bearer balances a bowl filled with food offerings on his left shoulder with both hands. ${ }^{55}$ The other two men carry bundles of three papyrus stalks in bloom. ${ }^{56}$ The scene is framed by a register line along the bottom edge and a vertically carved line along the right end. The undecorated dado shows faint traces of black paint, the outlines of a decorative band. ${ }^{57}$

\section{[11] Entrance doorway, north reveal: In situ + Brooklyn 37.39E (Fig. 21)}

\section{Limestone.}

In situ: H. 90 cm, W. $11.5 \mathrm{~cm}$; Brooklyn 37.39E: H. $65.5 \mathrm{~cm}, W .87 \mathrm{~cm}$, Th. $11 \mathrm{~cm}$.

Bibliography: NYHS, 1915, p. 2, no. 14; Fründt, FuB 3/2 (1961), p. 27; James, Corpus of Hieroglyphic Inscriptions, 1974, pp. 175-76 [431], pl. 85; Martin, Corpus of Reliefs, 1987, p. 22 [44], pl. 17. Raven et al., JEOL 44 (2012-13), fig. 8 (left); Staring, Saqqara 


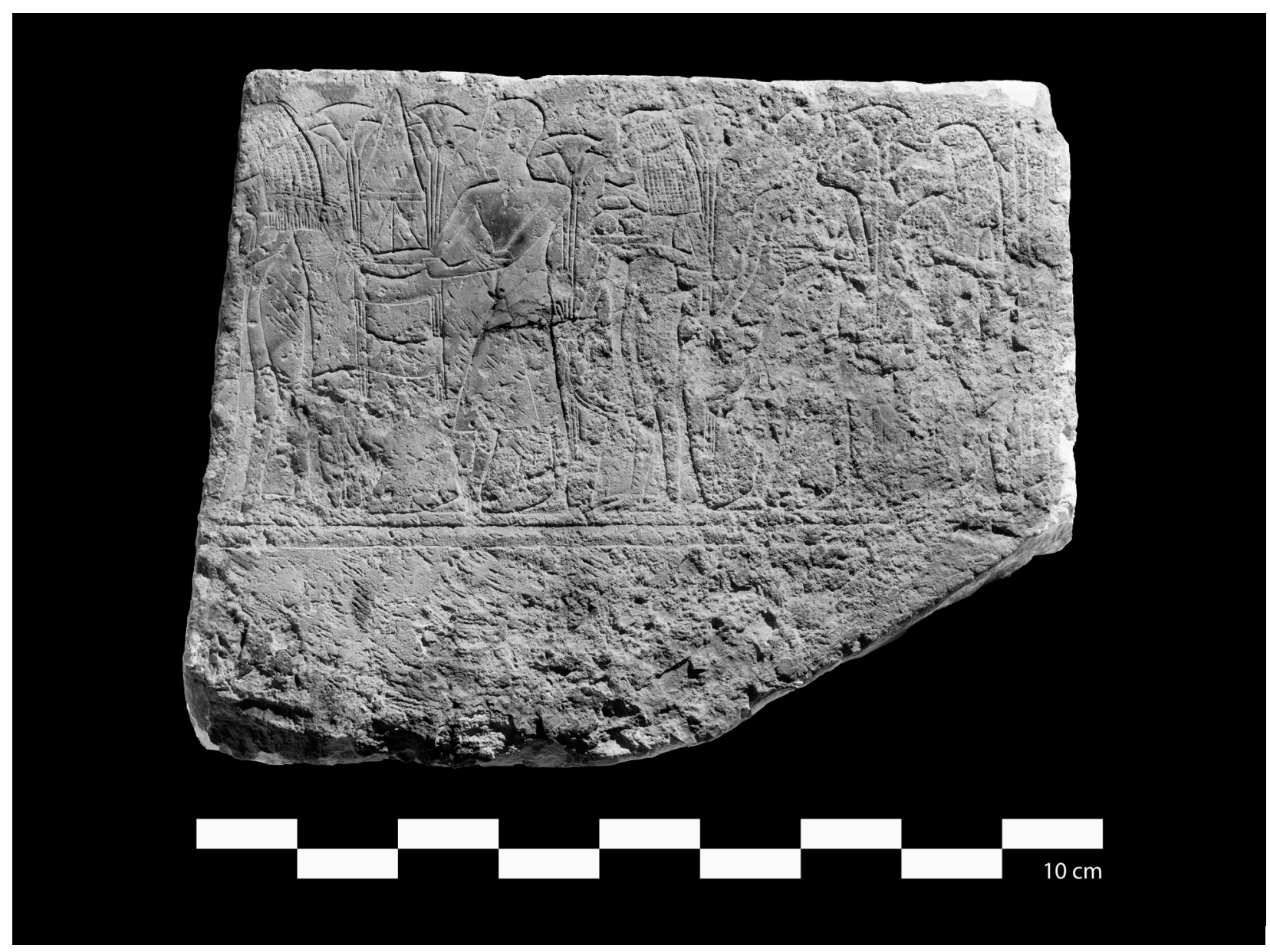

Fig. 21: Tomb of Ry, entrance doorway, north reveal: relief-decorated block Brooklyn Museum 37.46E. Image @Brooklyn Museum. Scan of a photograph held in The Martin New Kingdom Archive, adapted by Nico Staring.

Newsletter 16 (2018), fig. 7; Staring, EgArch 54 (2019), fig. on p. 44.

\section{Description}

The left-hand side of the scene has been preserved on the head end of the block with scene [10]. It comprises a vertical and horizontal block frieze along the left and lower ends of a scene which decorated the adjoining block to the right. ${ }^{58}$

The blocks of Ry held in Berlin were first studied in some detail by Fründt, who suggested that relief Brooklyn 37.39E also belongs to the same corpus. ${ }^{59}$ The Brooklyn fragment depicts a scene showing offering bearers (three female and two male, bringing forth assorted goods, including a live bull calf) in a style similar to that observed in the reliefs of Ry. The iconography would indeed fit the north wall of the entrance doorway and the block has the correct dimensions. If indeed correctly placed there, the row of offering bearers would continue their "procession" on the east and north walls of the antechapel.
However, the horizontal block frieze bordering the in situ scene [11] of Ry on the bottom edge is not the same as the frieze bordering the scene in block Brooklyn 37.39E. On the other hand, the frieze bordering the Brooklyn relief on the right-hand side is the same as observed on the block in situ in the tomb of Ry. It is possible that the lower line of the horizontal frieze bordering the scene along the bottom was not finished in its entirety. Something similar has been observed in block ÄM 7275, scene [7]. Thus, even though a direct join is absent, it is highly likely that the Brooklyn block derives from the tomb of Ry as well. The block's dimensions neatly fit the space available on the tomb wall. ${ }^{60}$

The block is much worn and damaged. For example only the outlines of the head of the fourth offering bearer are visible. Still, faint traces of text can be discerned. A column (?) of hieroglyphic signs incised between two column dividers (?) seems to read $\underline{h} r . y-\underline{h b} . t$, Lector Priest. 


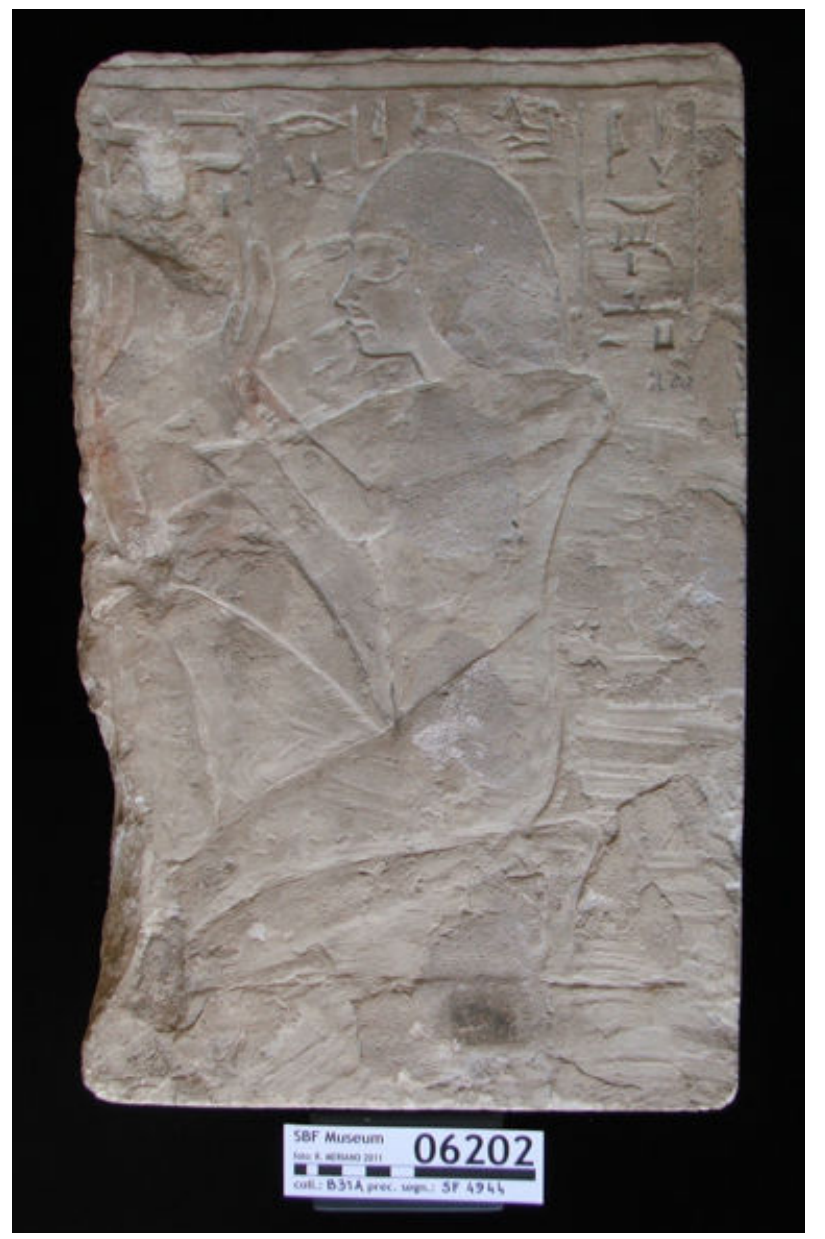

Fig. 22: Tomb of Ry, entrance doorway, right-hand side of the lintel: relief-decorated block Jerusalem, Studium Biblicum Franciscanum Museum CTS-SB-06202. Photo @Studium Biblicum Franciscanum/Roberta Meriano.

[12] Entrance doorway, right-hand side of lintel: Jerusalem, Studium Biblicum Franciscanum Museum inv. no. CTS-SB-06202 (Fig. 22)

\section{Limestone}

H. $42 \mathrm{~cm}$, W. $25.8 \mathrm{~cm}$; Th. $4.3 \mathrm{~cm}$.

Bibliography: Piccirillo, Studium Biblicum, 1983, p. 79, with fig. (as: "small stele"); Martin, Corpus of Reliefs, p. 22 [45], pl. 14.

Fragment of a relief-decorated block executed in sunk relief depicting Ry, kneeling and facing left, both hands raised in adoration. ${ }^{61}$ The remains of six framed columns of hieroglyphic text are preserved.

The top, right side, lower edge and back of the block are sawn and the relief shows traces of considerable modern repair.

On account of the block's dimensions and the scene depicted, it probably formed part of the right-hand

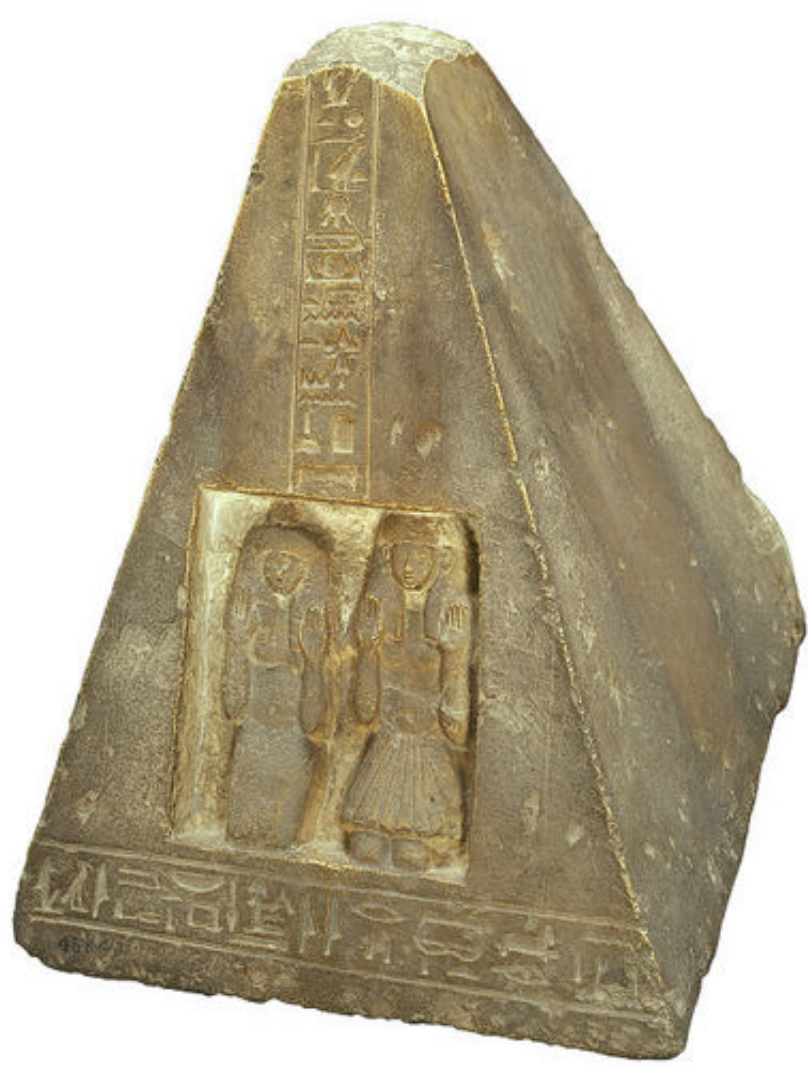

Fig. 23: Pyramidion Cairo, Egyptian Museum JE 48840 (formerly JE 14975), SR 13738. Photo @Egyptian Museum, Cairo.

side of the lintel over the doorway into the chapel. ${ }^{62}$ Such scenes commonly show the tomb owner in the company of his wife. Whether originally part of the doorjamb or lintel, a similar scene of the tomb owner in adoration, facing right, would have been present on the opposite side of the doorway.

\section{Texts}

$(\leftarrow \downarrow)^{\mathbf{1}}$ The Osiris ${ }^{\mathbf{2}}$ Chief of Bowmen ${ }^{\mathbf{3}-5} \mathrm{Ry}^{\mathbf{6}}$ true of voice, possessor of reverence.

\section{[13] Pyramid: Pyramidion Cairo, Egyptian Museum JE 48840 (formerly JE 14975), SR 13738 (Fig. 23)}

\section{Limestone}

H. $49 \mathrm{~cm}$ (orig. $57 \mathrm{~cm}$ ), W. base east $40 \mathrm{~cm}$, W. base south $48.5 \mathrm{~cm}$, W. base west $39 \mathrm{~cm}$ (orig. $40 \mathrm{~cm}$ ), W.†base north $47.5 \mathrm{~cm}$ (orig. $48.5 \mathrm{~cm}$ )

Bibliography: PM III/2, 770; Mariette, Catalogue 
général des monuments d'Abydos, 1880, pp. 558-59, no. 1432; Rammant-Peeters, Les pyramidions, 1983 , pp. 24-25, pl. 16 (43), Doc. 21.

\section{Description}

The pyramidion bears decoration and texts on its east side. Ry and Maia are represented as half-statues, sculpted in the centre of the east face. They kneel side by side and raise their hands in adoration. The text starts as a single framed column running from the top of the pyramidion down to the sculpted figures. It continues as a single framed line of text along the base of the pyramidion.

\section{Texts}

$(\downarrow \rightarrow)^{\mathbf{1}}$ [Adoring] Re when he rises in the eastern horizon of the sky ${ }^{2}$ by the $k a$ of the Osiris, the Chief of Bowmen, Ry, true of voice (and) the Lady of the House Maia.

\section{Date, iconography and style: A synthesis}

The descriptions of scenes in the previous section propose a number of parallels from contemporary and nearby tombs at Saqqara. Here I will treat the subject of style and iconography more coherently. However, this section is not meant to be an in-depth discussion of the broad, complex subject of style and iconography, which is beyond the scope of the present study. ${ }^{63}$ The present discussion of the subject is meant to situate the tomb of Ry in its spatial and temporal context and to propose a date for it.

The general style of the figures featured in the relief decoration points to a date in the late Eighteenth Dynasty. This date can be narrowed down to the reign of Tutankhamun, although some stylistic features observed in the scenes of Ry's tomb are reminiscent of the early years of Horemheb. The former include the very finely carved, almost "soft" facial features of Ry and Maia in the upper register of scene [6], the stela Berlin ÄM 7290. As far as style is concerned, the clothing (e.g. the post-Amarna period bag tunics worn by Ry and the officiants at the offering table), the shape of the heads and the proportions of the bodies are most distinctive. ${ }^{64}$ Parallels observed in neighbouring tombs corroborate a date in the reign of Tutankhamun. The garment worn by Ry in the upper register of the tomb stela ( $\ddot{\mathrm{AM}} 7290$,

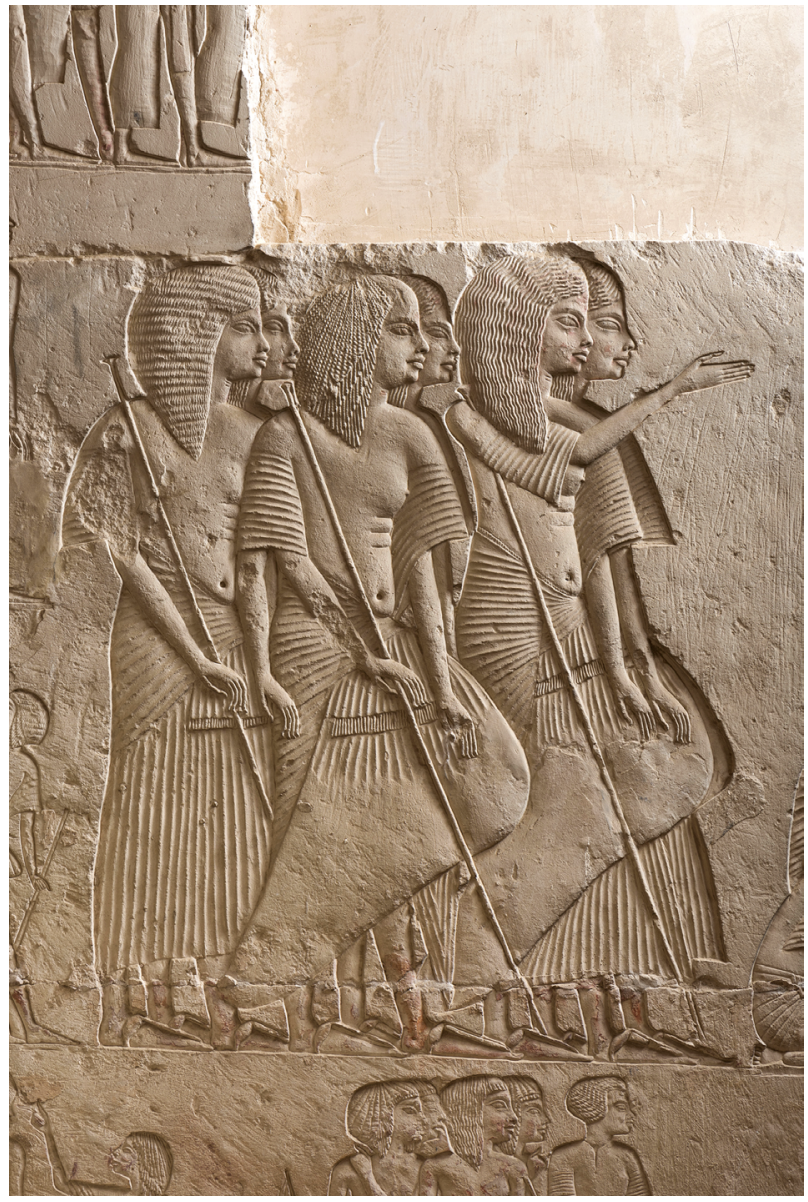

Fig. 24: Group of army officials as depicted in the tomb of Horemheb, inner courtyard, east wall, south end. Photo (-Leiden-Turin Expedition to Saqqara/Nicola Dell'Aquila.

fig. 12a) finds a close parallel in the nearby tomb of Horemheb (Fig. 24). The offering bearers in the tomb of Horemheb (Fig. 25) compare well with the figures in the tomb of Ry. The offering bearer named Pehefnefer is executed in a style very similar to the second (i.e. bald-headed) officiant in relief $\ddot{A M} 7278$, named Ahanefer (Fig. 26). Note, for example, the way in which the hairline is indicated, the shape and execution of their eyes and ears, and their kilts. However, there are also marked differences. For example, the figures in the tomb of Horemheb lack the distinctive folds in the neck. On the other hand, the relief-decoration in the tomb of Ry lacks the refined execution of details observed in the tomb of Horemheb. Compare, again, the kilts worn by Pehefnefer and Ahanefer. In the former, the lines indicating the pleats follow the shape of the body, whereas in the latter the lines are more straightforward and perhaps even less carefully carved, showing signs of mistakes. Similarly, one may also compare the ducks held by the male offering bearer in the tomb of Horemheb and the female 


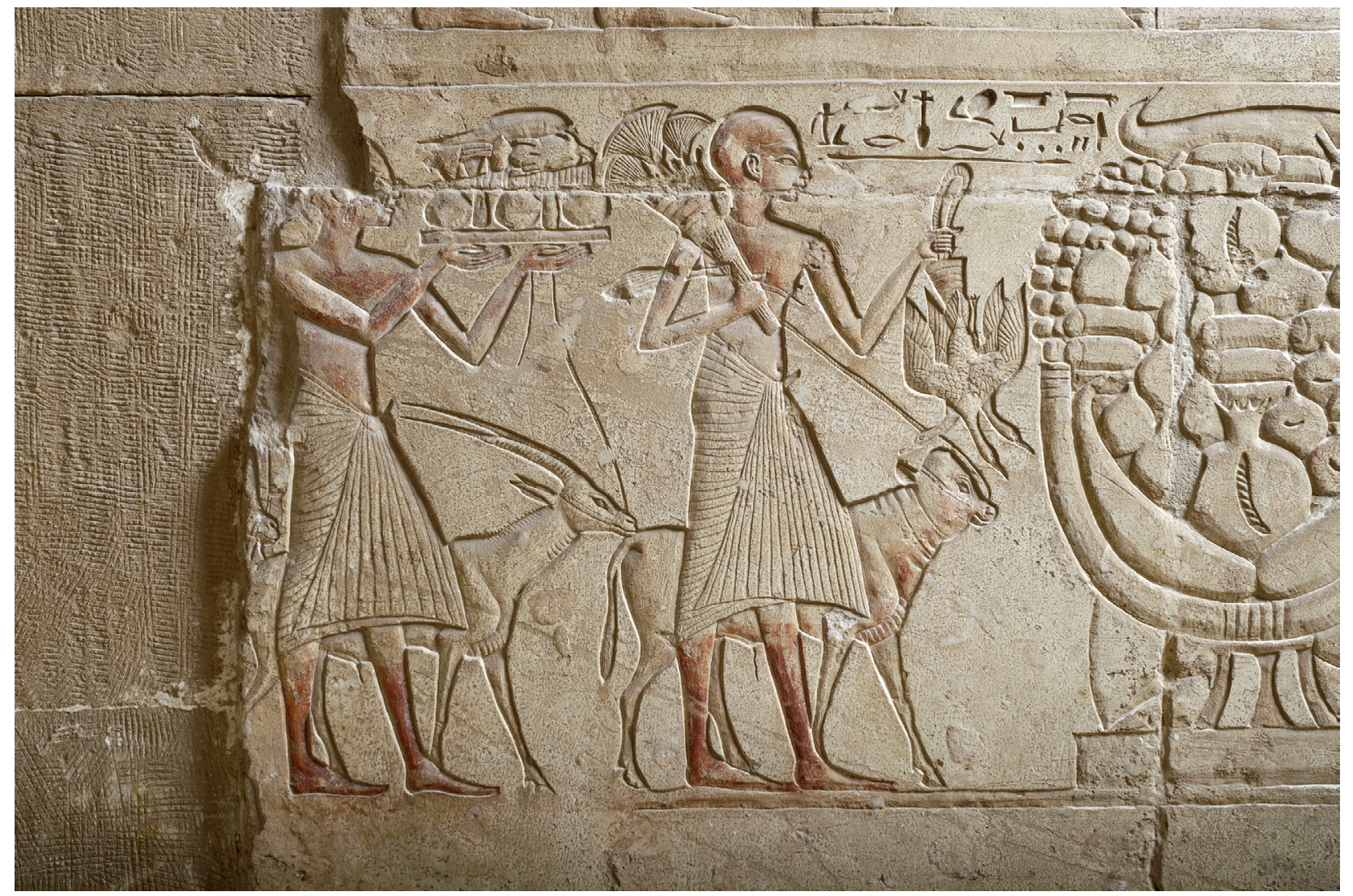

Fig. 25: Offering bearers in the tomb of Horemheb, statue room vestibule, south wall, lower register. Photo @Leiden-Turin Expedition to Saqqara/Nicola Dell'Aquila.

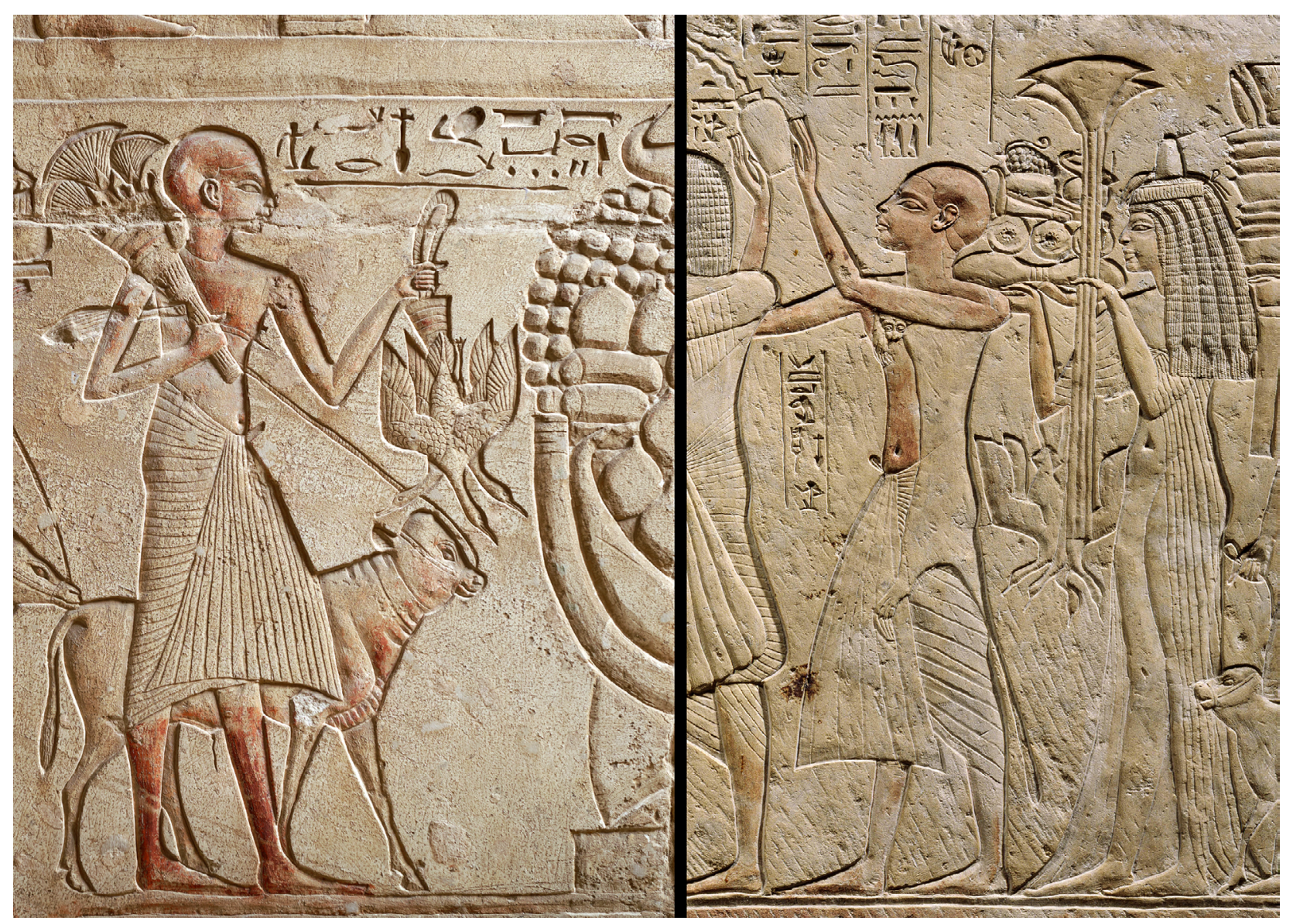

Fig. 26: Comparing the depictions of Pehefnefer in the tomb of Horemheb (left) and Ahanefer in the tomb of Ry (right: detail relief Berlin ÄM 7278). Photos @ Leiden-Turin Expedition to Saqqara/Nicola Dell'Aquila; SMB Ägyptisches Museum und Papyrussammlung/Jürgen Liepe 


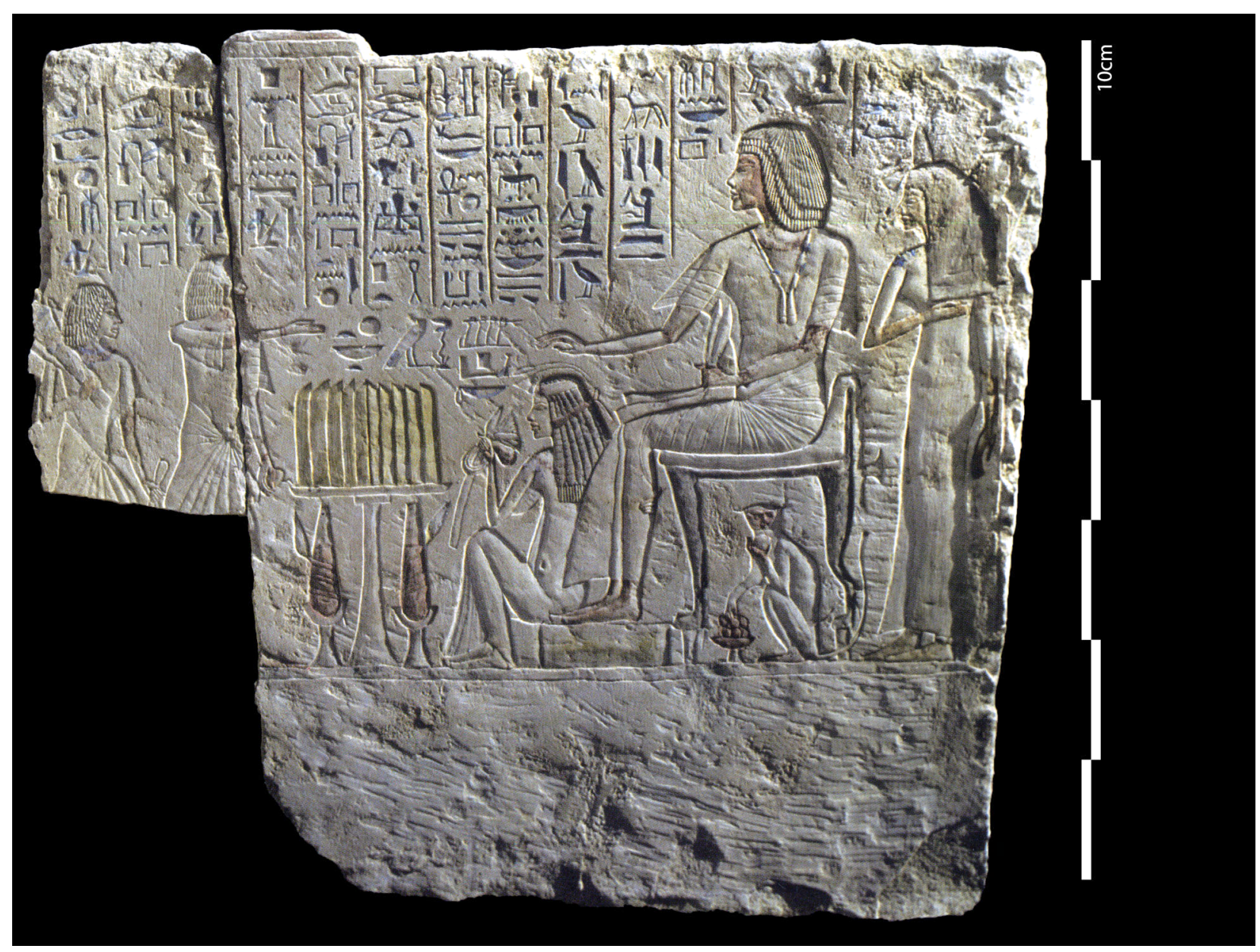

Fig. 27: Iniuia sitting at an offering table and his wife luy standing behind him. Depicted on the south wall of the antechapel. Photo ๑Rijksmuseum van Oudheden, Leiden, adapted by Nico Staring.

offering bearer in the tomb of Ry. Those in the tomb of Horemheb are executed with an eye for detail, indicating the beaks, eyes, and feather patterns, whereas those in the tomb of Ry are only indicated in outline. Also compare the flowering papyrus stalks held by both: again, all signs of internal detail are absent from the relief of Ry.

Other striking parallels are found in the neighbouring tomb of Pay. ${ }^{65}$ The relief decoration in the west part of that tomb is dated to the early reign of Tutankhamun, the east part to the king's later years, possibly extending into the reign of Ay or even the early reign of Horemheb. ${ }^{66}$ The reliefs and painted decoration added by Pay's son, Raia, have been dated to the late reign of Horemheb, at the earliest, and more probably to the early Nineteenth Dynasty (temp. Ramesses I-Seti I). Thus, the dates offered by the tomb of Pay and the additions made to it by Raia securely situate Ry in the earlier reign of Horemheb at the latest. This date is further corroborated by the position of the entrance to the forecourt built by
Raia, which indicates that the annex was built after Ry had started (and possibly finished constructing the superstructure of) his tomb.

The iconography of the scene reconstructed on the north wall of the antechapel of Ry, blocks R94-78 (Fig. 11), also finds a close parallel in the tomb of Pay, ${ }^{67}$ and two parallels in the tomb of Iniuia. ${ }^{68}$ One of the latter two scenes decorated the south wall of the antechapel (Fig. 27), as was the case in the chapel of Ry. ${ }^{69}$

The iconography in the tomb of Ry illustrates a movement from east to west, from the world of the living to the realm of the netherworld deities. The offering bearers proceed from east to west, and the deities Osiris and Re-Horakhty are depicted in the westernmost part of the chapel (Fig. 8). ${ }^{70}$ The iconography of scene [9], the scene of purification accompanied by the text's excerpt of BD spell $149 l$, is of particular interest. To my knowledge, there are no parallels for BD 149 spells or their accompanying vignettes in the iconographic programmes 
of New Kingdom tombs at Saqqara. As a matter of fact, the spell has not been widely observed outside of the Memphite necropolis either. Only four Theban tombs are known to have included text excerpts and/or vignettes illustrating BD $149 .{ }^{71}$ If we consider media other than tomb walls, it is interesting to note that in the late Eighteenth Dynasty BD manuscripts were often concluded with exactly this chapter, entitled "Spells for knowing the mounds of the house of Osiris in the Field of Rushes". 72 It has also been noted that some BD papyrus manuscripts add to it a final vignette showing the rising of the sun. ${ }^{73}$ This goes to show that, supposedly, the deceased passes the underworld mounds in the great bark of Re and, together with Re, enters the horizon after completing the nocturnal journey.

Given the fact that, in contemporary papyrus manuscripts, the spell was selected to conclude the document, and that the deceased passes the domain of Osiris and enters the horizon with the sun god, rejuvenated, the spell seems rather fit for inclusion in the antechapel. In the sanctuary, the deceased can be seen venerating the netherworld deities, Osiris and Re-Horakhty. It is where he remains forever in their presence. In the antechapel, the deceased is shown being on his way to those netherworld deities. As such, the antechapel may perhaps be seen as a space of transition between the world of the living (outside, i.e. the open courtyard), and the realm of the deities. In order for the deceased to make this transition and reach the netherworld deities, rituals such as the Opening of the Mouth were performed. Such rituals took place in the open courtyard preceding the chap$\mathrm{el}$, as is often illustrated in tomb decoration. ${ }^{74}$ There seems to have been a preference to depict scenes from the Opening of the Mouth on the north walls of tombs, possibly because the mummy or statue had to face south during the ritual. ${ }^{75}$ The relationship between the Opening of the Mouth ritual and the act of purification of the deceased is nicely illustrated on the Nineteenth Dynasty (temp. Ramesses II) stela of the Sculptor Qen from Deir el-Medina (Fig. 28). ${ }^{76}$ The stela depicts the Opening of the Mouth performed by Qen's son, Merymery, on the mummy standing in front of the tomb chapel. The upper register shows Merymery purifying his deceased parents by pouring water from a nemset jar. As in scene

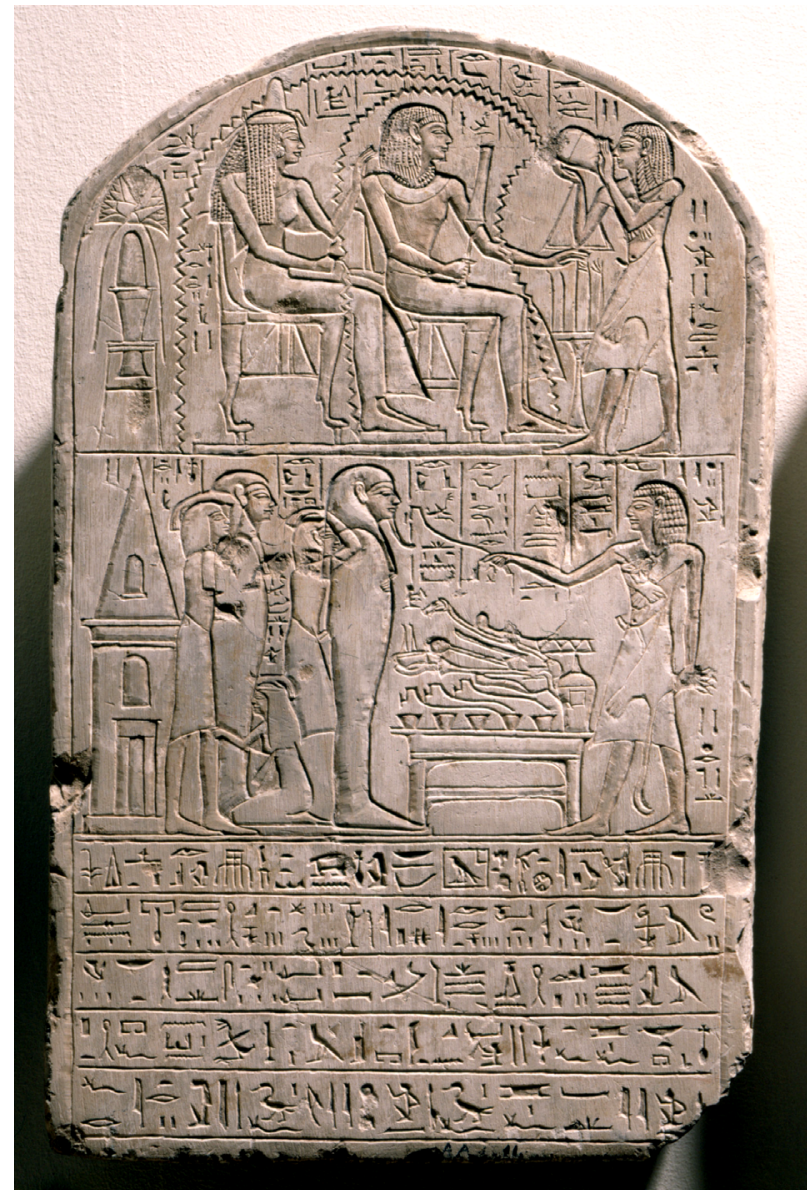

Fig. 28: Stela of Qen, Deir el-Medina. Copenhagen, Nationalmuseet AA.d.11. Photo courtesy of John Lee \& The National Museum of Denmark.

[9] of Ry, the wavy lines of water extend above the seated deceased couple. The iconography offers an excellent illustration of the course of events during the Opening of the Mouth and that which supposedly follows it. The spatial context of the tomb of Ry shows that the deceased is now ready to proceed to the west, where he will be able to give reverence to the netherworld deities.

The BD spell carved over the scene of purification further emphasises the transformation that has been made. It claims that Ry, now being an "Osiris" and an "embalmed one", has transformed into a goose, a reference to the sun god, and has ascended to the sky ready to partake in the offerings in the domain of Osiris. Following the purification ritual, here performed by members of his household, Ry reappears on the west wall of the antechapel, depicted in a striding pose as he faces the doorway into the inner sanctuary, which he is about to enter (scene [8]). Inside the westernmost part of the chapel, Ry and Maia face Re-Horakhty, the morning sun, and 
make adoration before the god (scene [7I). A similar scenario will have unfolded on the south walls of the antechapel and inner chapel (scenes [3-5]). There, Ry and Maia likely stood in adoration before Atum, the evening sun. ${ }^{77}$ Both deities are also the subject of the hymns carved on the stela(e) flanking the entrance to the west chapel. Then, the stela set in the chapel's west wall depicts the deceased couple venerating Osiris. Below the veneration scene, the mirrored image of Ry and Maia shows them sitting at an offering table. They receive food offerings brought to them by the offering bearers depicted on the north and south walls of the inner chapel.

Another way of interpreting the wall scenes in the tomb chapel of Ry is in the context of the solar-Osirian union, which includes the incorporation of the deceased and his family in this cosmological cycle. ${ }^{78}$ This interpretation might not necessarily contradict but rather complement the one put forward above. A more comprehensive examination and deeper analysis of this subject are of course needed, but fall beyond the scope of the present article.

To conclude this brief section, I would like to single out one iconographic particularity: the position of Maia's hand as she embraces her husband, Ry, in the purification scene [9]. She embraces him with her left arm, and her hand reappears on the chest of Ry. This embrace is very unusual in Memphite tomb decoration. ${ }^{79}$ In fact, I am aware of only three New Kingdom parallels:

1. Nefertary (also known as Tahesyt), seated, embraces her husband, the Overseer of Craftsmen and Chief Goldsmith of the Lord of the Two Lands Amenemone (temp. Tutankhamun). Both are depicted seated. The tomb is located in the Teti Pyramid North Cemetery. ${ }^{80}$ The embrace is featured in a scene on the southern screen wall, east face, of the antechapel.

2. Iuy, standing, embraces her husband, the Chief Steward of Memphis and Overseer of Cattle of Amun Iniuia (temp. Akhenaten-Tutankhamun; Fig. 29). ${ }^{81}$ The tomb of Iniuia is located ca. $30 \mathrm{~m}$ west of Ry. Fragments of this scene were found during excavation. The block formed part of the southern screen wall, east face, of the antechapel.

3. Tia, seated, embracing her husband, the Lector Priest of Amenhotep II Neferhat. The scene is depicted on the lower register of the stela of their son Ipu, a Royal Butler (temp. Tutankhamun), whose tomb is lost. ${ }^{82}$

The "Amarnesque" hands of Maia find their closest parallel in the scene of Iuy and Iniuia. ${ }^{83}$ It is tempting to regard these rather unusual features as being the products of a single artist. Indeed, it may not be too far-fetched to view some of these tombs as the products of a single group of artists (workshop). This applies in particular to the tombs of Ry, Pay/Raia and Iniuia. After all, they all share a similar iconographic programme (Fig. 30), and their owners were state officials and had their tombs constructed in precisely the same section of the cemetery. Another individual who could be added to this closely-knit group (and for whom a substantial corpus of relief-decorated blocks is available) is Paatenemheb, whose tomb was

\begin{tabular}{|c|c|}
\hline Related to the king, royal court, and & honorific) \\
\hline ir.y-pe.t ḩ.ty-e htm.ty-bi.ty smr-we.ty & 11.2 \\
\hline$h s . y \varsigma_{3}[n . y] n t r r n f r$ & II. 1 \\
\hline$m r r(. t y)(n . y) n b$ t3.wy $h r$ bỉ $. t=f$ & II.1 \\
\hline Scribal & \\
\hline$[s \check{s} n s w] m 3^{c} m r(. y)=f$ & II. 1 \\
\hline Military & \\
\hline$h r . y-p \underline{d} . t$ & I.1; I.2; I.5; II.1; II.2; III.1 \\
\hline im.y-r3 ssm. $(w) t$ & I.1; II.1 \\
\hline$s 3 b n(. y) m n f y(. t)$ & 11.2 \\
\hline
\end{tabular}

Table 3: Overview of titles held by Ry. Legend: I. 1 relief-decorated block Berlin ÄM 7278; I.2 relief-decorated block Jerusalem; II.1 stela Berlin ÄM 7290; II.2 stela Brooklyn 37.46E; III.1 pyramidion Cairo JE 48840 


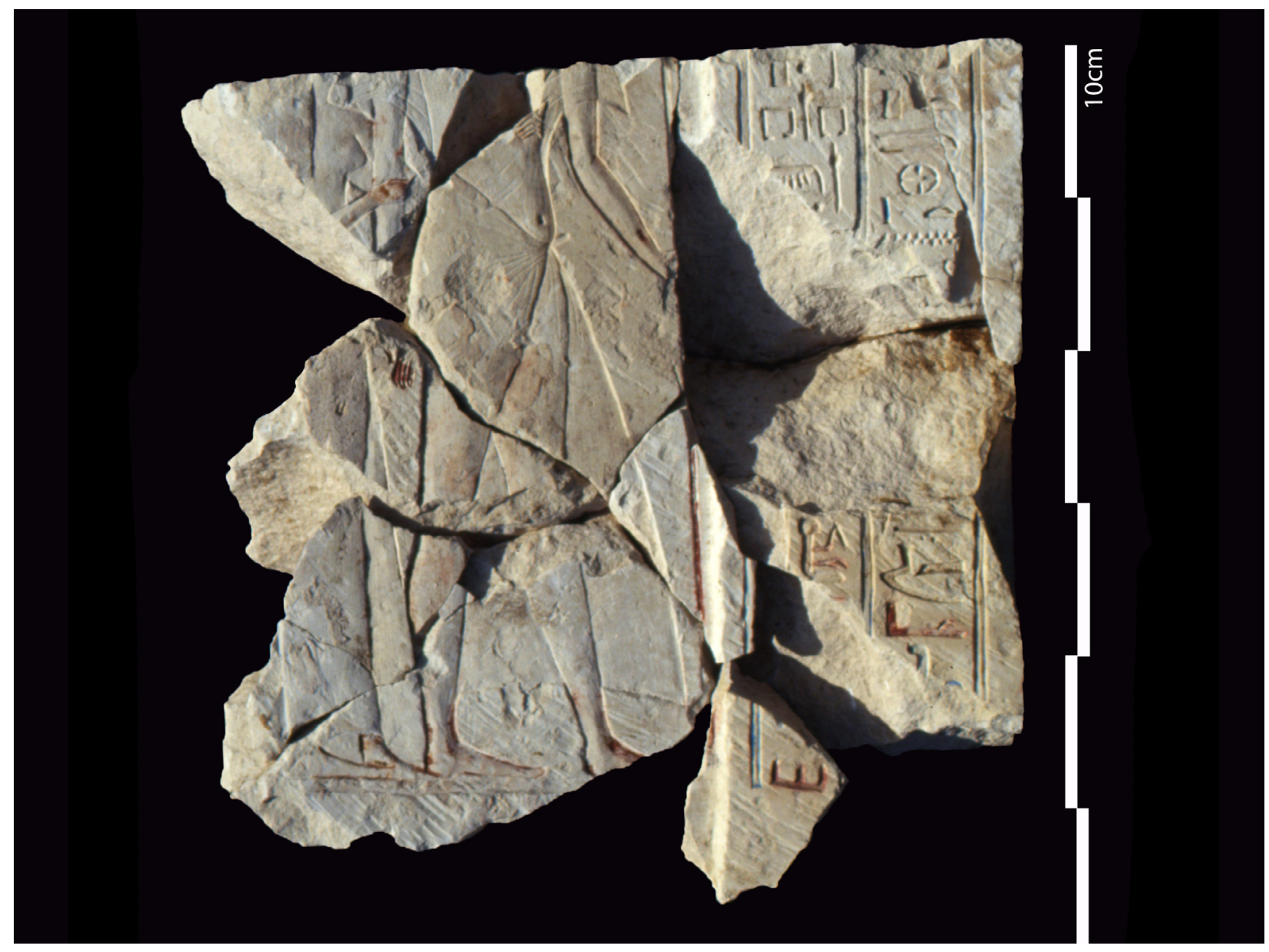

Fig. 29: Scene from the tomb of Iniuia and luy, antechapel, southern screen wall, east face. Photo @Rijksmuseum van Oudheden, Leiden, adapted by Nico Staring.

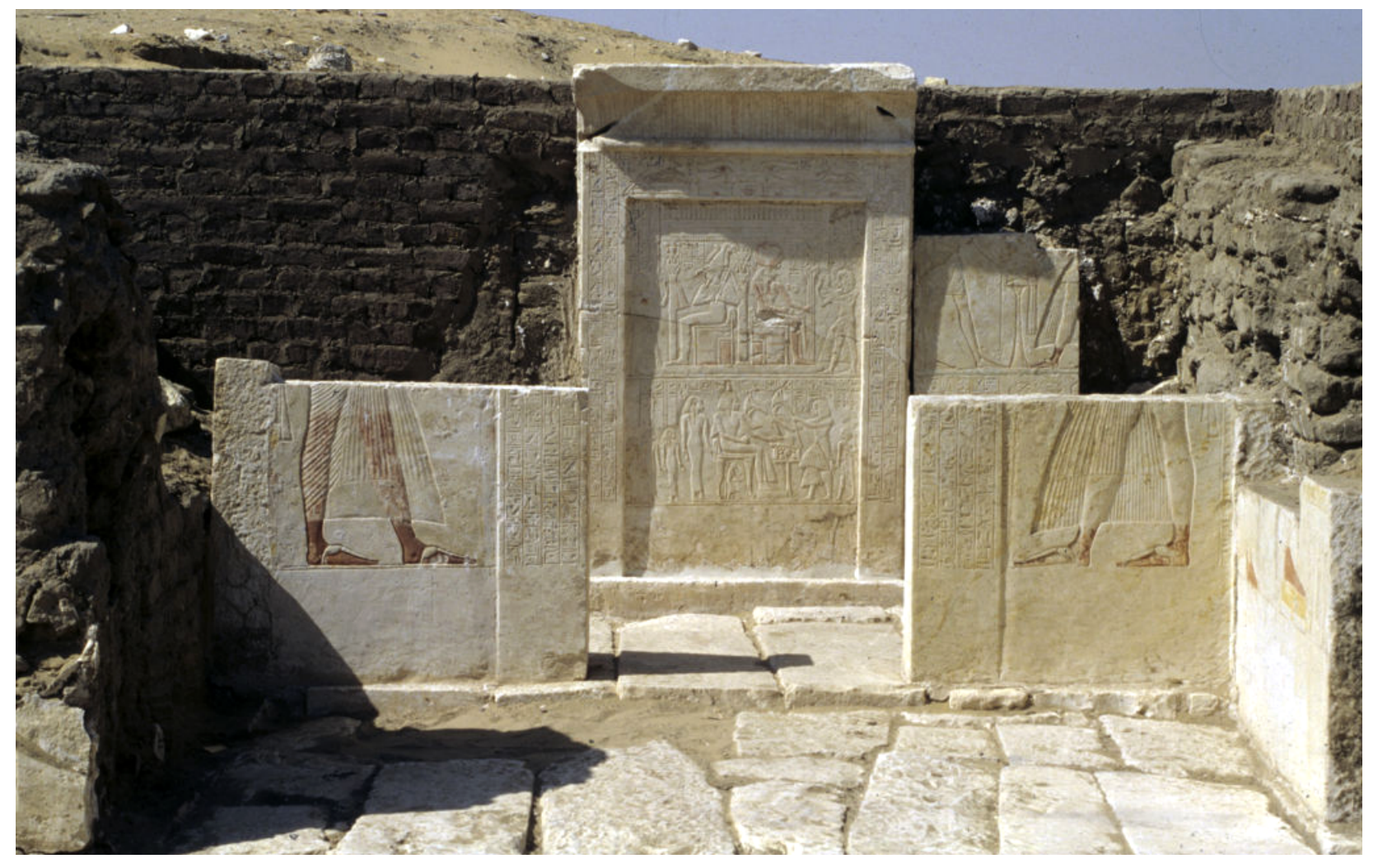

Fig. 30: The chapel of Pay at the end of the 1994 excavation season of the EES-Leiden mission, looking west. The iconographic programme of the chapel is similar to that of the chapel of Ry. The chapel of Pay is wider and includes screen walls. Photo @Rijksmuseum van Oudheden, Leiden. 
likely situated in the same section of the necropolis. All these individuals were professionally related and, as a result, may have had access to the same skilled workmen (possibly the same workmen who also worked on [parts of] the tombs of Horemheb and Maya), and whose distinctive handiwork is possibly recognisable in some specific iconographic and stylistic details in the tombs' relief decoration. ${ }^{84}$ On the other hand, one should also keep open the option that artists drew inspiration from the decoration in already extant tomb structures located nearby.

\section{Titles and epithets of Ry}

The inscribed relief-decorated blocks from the tomb of Ry allow a brief outline of the offices he held to be put together (Table 3).

\section{Honorific titles}

Honorific titles are a means to establish an official's social position and in particular his proximity to the king. ${ }^{85}$ Such titles are considered to be the most important markers of rank in the court. ${ }^{86}$ During the reign of Ramesses II, for example, only the highest administrators displayed the complete sequence of epithets ir.y-p'.t h3.ty-e htm.ty-bi.ty smr w'.ty, Noble and Count, Seal Bearer of the King of Lower Egypt and Sole Companion. ${ }^{87}$ It has been noted that in the Eighteenth Dynasty the epithet $s m r$ wr.ty signified a special relationship to the king. ${ }^{88}$ Ry's relationship to his king is also exemplified by the epithets that describe him as "One greatly praised by the Perfect God (i.e. the king)", and "One beloved of the Lord of the Two Lands on account of his character" ${ }^{89}$ These epithets indicate that he held a position within the king's inner circle $(\check{s} n . y t) .{ }^{90}$ Ry also received the Gold of Honour (see scene [6], stela Berlin ÄM 7290, and scene [7], Berlin ÄM 7275). This may have happened on the same occasion when he was awarded his epithets.

$s 3 b$ n.y mnfy.t $-s 3 b$ of the Army

The title $s 3 b$ n.y mnfy. $t$ has been variably translated as Judge/Senior of the Army ${ }^{91}$ and Scribe of the Army. ${ }^{92}$ Either interpretation of the $s 3 b$-element appears to be without parallel. The title Scribe of the Army was usually written as $s \check{s} m \check{s}$. That spelling, with the addition $n . y n b$ t3.wy, is observed in the tombs of a small number of officials buried at Saqqara, two of whom bear it as their single title of office. ${ }^{93}$ The title spelled with the standing jackal (Gardiner signlist E17) refers to the same office and can be regarded as an archaic form of it. ${ }^{94}$ It is not common for a military officer to bear scribes' titles related to the army (as opposed to the very common title of $s \check{s} n s w$, Royal Scribe). ${ }^{95}$

\section{hr.y-pd.t - Chief of Bowmen}

The Chief of Bowmen, casually translated as “Troop-Commander", is a military official with field experience in the infantry. The title's position in the lists of rank indicates that its bearer held one of the highest-ranking positions in the military. The hr.y$p d$.t was subordinate only to the im.y-rz $m \check{s}^{c} w r$, the General. $^{96}$

\section{im.y-r3 ssm.wt - Overseer of Horses}

Schulman suggests that the bearer of this title held a command in the chariotry, whose rank he does not specify. ${ }^{97}$ Gnirs, on the other hand, argues that the title denotes a command over the chariotry. ${ }^{98}$ This branch of the army was established in the mid-Eighteenth Dynasty reign of Amenhotep III. Yuya, the father-in-law of that king, was the first to bear the title in combination with military offices. ${ }^{99}$ Overseers of horses, or Commanders of the Chariotry, were drawn from the ranks of Chiefs of Bowmen. ${ }^{100}$ It usually is the highest-ranking title held by these officials. ${ }^{101}$

\section{Excursus: Officials at Saqqara Bearing the Titles Chief of Bowmen and Overseer of Horses}

There are a number of Memphite officials who bore either of the two titles held by Ry. ${ }^{102}$ The combination of the two titles is rare. Prominent bearers of the combination of titles, Chief of Bowmen and Overseer of Horses (of the Lord of the Two Lands) are Ay, Paramessu (Ramesses I), and Seti (Seti I): all military officials who became king in the post-Amarna period. ${ }^{103}$ Two officials buried at Saqqara held the same combination of titles of office: ${ }^{104}$

\section{Parennefer}

- hrr.y-pd.t. | im.y-rз ssm.wt

- Late Eighteenth Dynasty, temp. TutankhamunHoremheb.

- Mentioned and depicted in the tomb of his 
brother, Maya, the Overseer of the Treasury in the reigns of Tutankhamun and Horemheb. ${ }^{105}$

2. Suty

- hr.y-p d.t n.y nb t3.wy | im.y-rз ssm.wt

- Late Eighteenth Dynasty, temp. Tutankhamun (?).

- Relief-decorated block found reused in a Coptic period staircase built in the south-east corner of the outer courtyard built by Raia, son of Pay. ${ }^{106}$

The tomb of Maya, where Parennefer features in the wall decoration, is located ca. $50 \mathrm{~m}$ north of Ry's tomb, and the block inscribed for Suty was found reused in the forecourt of Raia, abutting the central chapel of Ry. Both these officials were contemporaries of Ry. Thus, the two men could have very well been comrades in the army. Raia, who is Ry's immediate necropolis-neighbour to the west, also made a career in the military: ${ }^{107}$

\section{Raia}

- hr.y ỉh.w | ir.y-pd.t n.y nb t3.wy | im.y-rз ssm.wt

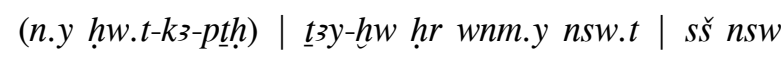
$\left(m 3^{c} m r . y=f\right) \mid$ im.y-rз ip.t-nsw.t | im.y-rз ip.t-nsw.t n.t (pr-hnnr.t m) mn-nfr | im.y-rз ip.t-nsw.t n.t (prhnr.t m) hw.t-k3-pth

- Late Eighteenth-early Nineteenth Dynasty, temp. Horemheb-Seti I.

- Tomb LS 28 shared with his father, the Overseer of Cattle of Amun and Overseer of the King's apartment at Memphis. ${ }^{108}$

According to Gnirs, the honorific title ir.y-pd.t n.y $n b$ t3.wy, Keeper of the Bow of the Lord of the Two Lands, implies a personal relationship between its bearer and the king. ${ }^{109}$ Raia started his career as a Stablemaster ${ }^{110}$ and eventually rose to the rank of Overseer of Horses. The latter title implies that he had also been a Chief of Bowmen earlier in his career, perhaps at the same time as Ry.

Another three officials at Saqqara bore the titles hr.y-pd.t and im.y-rz ssm.wt in combination with additional titles:

\section{Ramose}

- nfr bỉ.t | hs.y n.y nsw ḥr bỉ.t=f nfr.t | ḥs.y n.y nțr $n f r\left|g r m 3^{e}\right| s \check{s} n s w\left|s \check{s} n s w m^{e} m r . y=f\right| h m-n \underline{t} r \mid$

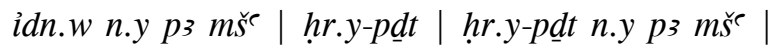
hr.y-pdt n.y nb tz.wy

- Late Eighteenth Dynasty, temp. Horemheb.

- Tomb structure situated immediately due north of Horemheb. ${ }^{111}$

\section{Amenhotep Huy}

- ir.y-pe.t | ḩ3.ty-e | sdisw.ty-bỉ.ty | smr we.ty | im.y-rз k3.t nb n.y psd.t (?) | im.y-rз mše wr n.y ḥm=f | ḥr.y-pd.t n.y ntr nfr | im.y-r3 ssm.wt n.y nb t3.wy $\left(t^{e} r . n . y\right.$ ntr $\left.n f r\right) \mid m r . y n b$ t3.wy $\mid$ š̌ n.y s.t wr.t $\mid s \check{s}$ nfr.w n.y $n b$ t3.wy

- Late Eighteenth Dynasty, temp. Amenhotep III-Tutankhamun.

- Amenhotep Huy shared the tomb of his father, the Vizier Aper-El (Bubasteion I.1). ${ }^{112}$

\section{Nakhtmin}

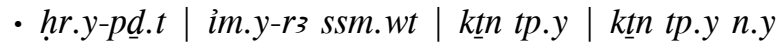
hm=f | im.y-rз ktn.w n.w ntr nfr | im.y-rз h̆zs.wt | im.y-rз ḩзs.wt mh.wt | wpw.ty nsw.t r hass.t nb.t

- Early Nineteenth Dynasty, temp. Seti I-Ramesses II.

- Rock-cut tomb at Saqqara North, above Abusir village. ${ }^{113}$

The tombs built for bearers of the titles also held by Ry are, in the post-Amarna period, noticeably clustered in the section of the Saqqara necropolis south of the Unas causeway. ${ }^{114}$ The same goes for Stablemasters. ${ }^{115}$ In the tomb of Ry, a Stablemaster named Maia plays the role of officiant performing the offering and purification ritual in scene [9]. He is professionally associated with Ry and may therefore be counted as a member of his social circle. In the tombs surrounding Ry, more Stablemasters can be found. They feature as subsidiary figures in the iconographic programmes of tomb owners bearing more elevated titles of office. Both the brother and son of Pay, Ry's neighbour, held the title. ${ }^{116}$ The same goes for two sons of Tatia, Ry's neighbour to the east. Tatia was a Wab Priest of the Front of Ptah and Chief of the Goldsmiths. ${ }^{117}$ Further to the west, north of the tomb of Pay and built against the south-exterior wall of the tomb of Horemheb, lies the chapel of Khay II, another Wab Priest of the Front of Ptah. ${ }^{118} \mathrm{~A}$ son of this priest, named Mose, also bore the title of Stablemaster of the Lord of the Two Lands. ${ }^{119}$ 


\section{The tomb of Ry in its spatial context}

What did the necropolis look like when Ry had his tomb constructed there, and how did it develop thereafter (Figs. 1, 2)? To answer this question, the spatial development of this section of the Unas South Cemetery will be briefly reviewed. Three phases of the cemetery's development will be considered: first, the period shortly before Ry built his tomb; second, the time period contemporaneous with Ry (i.e. construction of the tomb); and third, the time period following Ry's death.

The first phase is most difficult to review, because we are rather ill-informed about the history of the necropolis at Saqqara before the Amarna period. Various sources indicate that tombs were built in the Unas South Cemetery during the reign of Amenhotep III. Early modern excavators found abundant tomb elements from that period. ${ }^{120}$ Unfortunately, the locations of the finds were poorly recorded, if at all. Thus, the locations of their corresponding tombs have been lost. The information recorded on the tomb elements combined with a comparative study of provenanced finds could tell us something about who was buried where, but does not tell us anything about the structure of the cemetery at the time. It has been suggested that the pre-Amarna tombs were built as (partially) rockcut tombs ${ }^{121}$ and that the common Memphite freestanding temple-tomb superstructures represent a later phase in the development of this cemetery. Finds of mud bricks stamped with the prenomen of Amenhotep II (Aakheperure) are indicative of possibly the earliest building activities at the site. It is not at all certain whether these bricks were used in the construction of one or more private tombs, or derive from structures of a different nature. ${ }^{122}$

We are on firmer ground in the second phase, namely the period when Ry started building his funerary monument. The earliest tomb structures excavated (in modern times) in the Unas South Cemetery span the Amarna Period reigns of Akhenaten and Tutankhamun. A number of these tombs are truly monumental. Thus, the plot selected by $\mathrm{Ry}^{123}$ to build his tomb was surrounded by, at the time, fairly new monuments. Ry's neighbour to the west was Pay, the Overseer of Cattle and Overseer of the King's apartments at Memphis (temp. Tutankhamun); ${ }^{124}$ to the north stood the tomb of Meryneith, the Greatest of Seers (High Priest) and Steward in the Temple of the Aten in Memphis (temp. Akhenaten- Tutankhamun); ${ }^{125}$ and his neighbours to the east and south are thus far anonymous. ${ }^{126}$ Moreover, within a radius of $50 \mathrm{~m}$ were the tombs of two of the most prominent officials of Tutankhamun's tenure: Horemheb, the great General, and Maya, the Overseer of the Treasury. To these tombs, both of which have been archaeologically surveyed, we could add the prosopographic information recorded on tomb-elements deriving from the same section of the cemetery and now kept in museum collections worldwide. As a result, an image emerges of a cemetery reserved exclusively for courtiers. They include stewards of royal memorial temples, royal butlers, high ranking army officials, overseers of (royal) construction works, "harem" officials, and high priests. ${ }^{127}$

The third phase pertains to the time period following the burial of Ry. The brief discussion here will be limited to developments in the early Nineteenth Dynasty. Changes were made to existing tombs and new chapels were sometimes added. As a result, the available spaces between pre-existing structures decreased. The son of Pay, Raia (temp. Horemheb-Seti I), enlarged his father's tomb by constructing an open forecourt. The free space between the tombs of Ry and Pay was clearly limited. Space constraints influenced the form and layout of the newly built annex. ${ }^{128}$ The walled court is asymmetrical and it is aligned with the west face of Ry's pyramid (Fig. 2). An axial approach to the new tomb entrance was not an option. Instead, the builders had to shift the doorway to the north. ${ }^{129}$

In the areas to the north and east of the tomb of Ry, more chapels dating to the (early) Ramesside period dot the map. These chapels are all founded on a higher surface compared to the floor level of Ry, the result of an accumulation of tafl from the excavation of the underground burial spaces of the Ramesside chapels. Directly in front of the tomb of Pay and Raia stood a chapel of which today only the stela emplacement and tomb shaft survive. ${ }^{130}$ In the same general area stood another two funerary monuments. The one built halfway between Meryneith and Ry is noteworthy. It comprises a four-sided stela inscribed for a Stonemason named Samut. The stela 
stood there apparently without an accompanying superstructure - at least not one built in durable material, such as mud bricks. ${ }^{131}$ The space east of Ry was occupied by a chapel built for a Priest of the Front of Ptah, Tatia. ${ }^{132}$ A final chapel, numbered 2013/7, was positioned right against the south side of the east facade of Ry's tomb. ${ }^{133}$ This chapel also dates to the Ramesside period. The walls south of it may be of the same date. The nature of the relationship between the two needs to be further investigated in the field. The porch leading up to the entrance doorway of Ry's tomb may have been constructed in conjunction with the building activities just described. In so doing, Ry, or rather those responsible for the tomb's maintenance (perhaps members of his household), changed the approach to the monument. The new construction "funnelled" visitors from the north towards the south, and fenced off the tomb entrance from the tafl accumulating outside. The position of the shaft connected to the chapel built against the facade of Ry's tomb (if identified correctly) suggests that the "dead-end road" leading up to it served as its courtyard.

\section{Ry's neighbour to the south: The Army General, Amenemone?}

In the section dealing with the architecture of the tomb, it was noted that Ry had his tomb built against a pre-existing wall. The structure that wall belongs to has yet to be fully excavated. It is very likely that it is also a tomb. Judging from the monumental dimensions of the wall, the individual for whom it was built was a high-ranking official. That Ry built his tomb against it may indicate that the two men were closely associated in life. Their relationship could have been professional in nature or based on kinship. The question I would like to address here is: who was buried south of Ry?

The spatial distribution of tombs according to the titles held by their owners may help us to identify Ry's southern neighbour. ${ }^{134}$ The bearers of certain titles are clustered in specific sections of the Saqqara necropolis. ${ }^{135}$ Starting from this observation, I have previously tried to identify the section of the necropolis where the "lost" tomb of Amenemone (late Eighteenth Dynasty, temp. Tutankhamun-Horemheb) was most likely situated. Amenemone held a great num- ber of titles, including im.y-r3 mšc $w r$ (n.y $n b$ t3.wy), General (of the Lord of the Two Lands) and im.y-rz

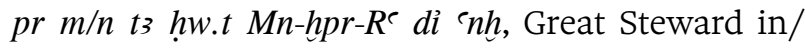
of the temple of Thutmosis III. ${ }^{136}$ Stone elements deriving from his tomb are dispersed in many public and private collections around the world. ${ }^{137}$ The only indication for its supposed location was given by Karl Richard Lepsius. In 1843, he noted that various blocks inscribed for Amenemone were reused in the masonry of houses at Abusir village. ${ }^{138}$ His observation has led scholars to suggest that the lost tomb should be situated in the vicinity of that village in northern Saqqara. ${ }^{139}$ In my view, the titles held by Amenemone suggest that his tomb was situated not in northern Saqqara, but in the Unas South Cemetery. ${ }^{140}$ In precisely this section of the necropolis a number of (near-)contemporary, late Eighteenth Dynasty im. $y w-r 3$ mš $w r . w$, Generals of the Army, built their tombs. The most prominent among them is the future king Horemheb. ${ }^{141}$ It is also the section of the necropolis "inhabited" by a number of high officials who administered royal memorial temples at Saqqara and at Thebes. ${ }^{142}$

With the identification of the tomb of Ry in precisely this section of the necropolis, additional evidence can be added to the discussion. Pivotal to the argument is the fact that, at an earlier stage in his career, Amenemone held office as Chief of Bowmen. It is very unusual for bearers of that title to rise to the rank of General. ${ }^{143}$ The office usually paves the way to becoming an Overseer of Horses, as did Ry. In the immediate post-Amarna period some military officials made unusual steps in their careers. Amenemone's unusual career has been explained in view of the administrative reformations implemented by Horemheb early in his reign. ${ }^{144}$ These reformations also affected the organisation of the military, resulting in the sudden rise to prominence of a number of army officials. One of them was Paramessu, the future king Ramesses I, who started his military career as an Overseer of Bowmen. He first rose to the rank of Overseer of Horses and eventually shifted ranks to become General and later Vizier. ${ }^{145}$ It has also been noted that the position of commander-in-chief of the army was occupied by only one official at any given time. ${ }^{146}$ Thus in the reign of Horemheb, Amenemone was the highest ranking official in 
charge of the army. He succeeded Horemheb, who had become king. At the same time, another official, Paramessu, took up Horemheb's offices in the civil administration. ${ }^{147}$

The contemporaries Amenemone and Ry held the same ranks in the army. All changed when Horemheb became king: Ry's acquaintance (if assessed correctly) obtained the highest office in the army. Their close professional relationship in life may have led to their tombs being intentionally placed in close proximity to each other. The spot selected by Ry became prime cemetery real estate since it was located in close vicinity of the now-royal tomb of Horemheb. ${ }^{148}$

\section{From disiecta membra to writing a history of the early modern excavations at Saqqara}

When was the tomb of Ry first excavated and how did the various tomb elements end up in museum collections around the world? This section is meant to provide a brief outline of the early modern excavation of the tomb by bringing together the collection histories of the individual tomb elements.

The first documented excavations at Saqqara date to the early 1820s. This was during a time of a growing interest in Ancient Egyptian antiquities, which led to a surge of art collectors, dealers, agents and gangs of local workmen exploiting the Saqqara plateau in search of valuables and collectables. Portable ancient Egyptian objects and inscribed tomb-elements were transferred to the private collections of Europeans living in Egypt. The subsequent sales of their private collections contributed to the dispersal of entire tomb structures. The tomb of Ry suffered this fate as well.

The relief-decorated blocks now held in the Egyptian Museum in Berlin were removed first. They entered the private collection of Giuseppe (Joseph) Passalacqua (1797-1865), an Italian horse-dealer who took to excavating and collecting antiquities in Egypt. ${ }^{149}$ He built his collection in the early 1820s and offered it for sale in Paris in $1826 .{ }^{150}$ In the following year, Friedrich Wilhelm III of Prussia acquired it for the Egyptian Museum in Berlin. The collection included stone elements from at least eighteen New Kingdom tombs located at Saqqara, mostly stelae. ${ }^{151}$ At the time, the objects' exact provenances were not recorded. Recent excavations in the Unas South Cemetery have unearthed tomb-elements deriving from the same tombs previously visited by Passalacqua. Relief-decorated blocks from the tomb of Wepwawetmes were found near the southwest chapel of the tomb of Horemheb ${ }^{152}$ and perhaps south of the tomb of Ptahemwia, reused in the dry-stone wall around the shaft of Tatia, ${ }^{153}$ and two blocks from the tomb of Panehsy were found south of the south exterior wall of Horemheb. ${ }^{154}$ The stela of Ramose, Deputy of the Army, could be contextualised when the entire tomb was excavated north of the northwest chapel of Horemheb. ${ }^{155}$ The small chapel of Khay, Gold Washer of the Lord of the Two Lands, is situated in the cramped space between the tombs of Horemheb and Ramose. ${ }^{156}$ These finds suggest that the agents working for Passalacqua concentrated their excavations in the area south of the Step Pyramid. His illustrious contemporaries, Giovanni d'Anastasi and Giuseppe Nizzoli, did the same. ${ }^{157} \mathrm{~A}$ few years after Passalacqua, in 1843, the expedition led by Prussian scholar Karl Richard Lepsius (1810-84) set up camp at Saqqara. Lepsius does not mention Ry, but we do know that he worked close by. Two stelae inscribed for Raia stood just a few steps west of the chapel of Ry. ${ }^{158}$ Lepsius numbered the tomb LS 28 and indicated it on his map. The two stelae were subsequently taken to Berlin, where they received inventory numbers ÄM 7270 and 7271.

The Englishman Henry Abbott (1807-1859) was a former physician in the army of Muhammad Ali. ${ }^{159}$ He settled in Cairo in 1838, where he acquired a collection of more than 1,200 objects. ${ }^{160}$ This included the Brooklyn stela formerly in the courtyard of Ry's tomb and the relief-decorated block from the entrance doorway. There is no information about the circumstances of their acquisition. Abbott narrates that he "found it an agreeable pastime to dive into the tombs of the ancients and rescue from the hands of the many pilferers such objects as appeared (...) worthy of notice". ${ }^{161}$ Others assured that "[m]any of the objects were found in tombs opened in the presence of Dr. Abbott". ${ }^{162}$ Whether or not Abbott was personally involved in the excavation of the stela is not known. We do know that he bought predominantly from dragomans and art dealers. Thus, he may not have witnessed the stela and relief block be- 
ing removed from the tomb. Since the two elements were located in close proximity at the entrance to the chapel, it is likely that they were both removed by the same (group of) excavator(s) at the same time. Abbott's private collection was eventually shipped from Egypt to the U.S. in 1851-52. There it was acquired by the New York Historical Society (NYHS) in 1860. The NYHS collection was later transferred on loan to the Brooklyn Museum, which eventually purchased it in 1948.

The pyramidion of Ry was first thought to have come from Abydos. According to his own recollection, Auguste Mariette (1821-81), the first director of the newly founded Egyptian Antiquities Service, had excavated it there on the east slope of the central cemetery. ${ }^{163}$ Curiously, in the Journal d'entrée of the Egyptian Museum in Cairo, it is noted that the object was found "at Memphis". ${ }^{164}$ The apparent mixup has recently been cleared. Mariette's unpublished inventaire, the precursor of the Journal d'entrée, lists the pyramidion among the finds he made at Saqqara in February $1861 .{ }^{165}$ In the late 1850s and early 1860s, Mariette engaged in excavations south of the Step Pyramid at Saqqara to gather a collection for the soon-to-be-opened Boulaq Museum. ${ }^{166}$

The tomb of Ry probably disappeared again below the desert sand soon after Mariette's exploration. It was not until 1906-1907 that James Quibell (18671935) shifted attention to a previously unexplored area to the south of the Step Pyramid. ${ }^{167}$ There, Egyptian sebakhin had uncovered a wall decorated with murals of the former Coptic monastery of Apa Jeremias. Quibell carried out large-scale excavations, which yielded many relief-decorated blocks of New Kingdom date. These blocks had been taken from the nearby tombs in the early centuries CE and reused in the construction of the monastery's buildings. At the beginning of the twentieth century, undocumented and illicit digging probably continued, because new objects appeared on the art market after Quibell closed his excavations in 1912. The German Fr. Cleophas Steinhauser (1872-1927), who moved to Egypt in 1904 to become a friar in the Franciscan Order and cemetery keeper of the mission in 1907, gathered his collection of antiquities in the first two decades of the twentieth century. ${ }^{168}$ He often had local villagers collect ancient objects which he then examined and eventually bought. It is not known exactly when, from whom or under what circumstances he got possession of the relief-decorated block from the tomb of Ry. ${ }^{169}$ And it is not known when the block was removed from the tomb of Ry, or by whom. Steinhauser presented his collection, which amounted to more than 1,000 objects, to the Studium Biblicum Franciscanum in Jerusalem in the 1920 s. ${ }^{170}$ The collection is scheduled to be on permanent display in the Terra Sancta Museum.

The virtual reconstruction of the tomb as presented in this article shows that a significant number of relief-decorated blocks and at least one stela are still missing. It is hoped that continued excavations at Saqqara and arm-chair archaeological work will improve our understanding of the monument, its place in the development of the Saqqara necropolis, and its early-modern excavation history.

\section{Acknowledgements}

This article was written with financial support of a Vidi Talent Scheme research grant awarded by the Dutch Research Council (NWO), dossier no. 016.Vidi.174.032. The project, The Walking Dead at Saqqara: The Making of a Cultural Geography , is hosted at the Leiden University Institute for Area Studies, School of Middle Eastern Studies (20172022). I would like to thank the Walking Dead team members, Lara Weiss and Huw Twiston Davies, as well as Barbara Aston, Maarten Raven, the two anonymous reviewers of the Rivista del Museo Egizio and its editor-in-chief, Federico Poole, for their kind feedback and suggestions on earlier drafts of this article; and Robbert Jan Looman and Peter Jan Bomhof for access to the Saqqara photo archive at the Rijksmuseum van Oudheden, Leiden. The opinions expressed in this article as well as any mistakes obviously rest solely with the author. As a token of appreciation, I would like to dedicate this study to Geoffrey T. Martin, the initiator of the modern excavations in the Unas South Cemetery, who generously shared with me his personal archive of New Kingdom Memphite material. Photos kept in The Martin New Kingdom Archive allowed me to unlock the identity of the tomb owner discussed in the present paper. 


\section{Notes}

${ }^{1}$ PM III/2, p. 716; Ranke, Personennamen, 1935, p. 216,29 . There is no relationship with Ry, the early Nineteenth Dynasty owner of TT255, who held the title im.y-rз pr m pr hr-m-hb m pr Imn, Steward in the house of Horemheb in the house of Amun (Baud and Drioton, Le tombeau de Rö̈, 1928).

${ }^{2}$ Raven et al., JEOL 37 (2003), p. 97, fig. 3; Regulski et al., JEOL 42 (2010), pp. 30-37, fig. 3.

${ }^{3}$ Raven, Pay and Raia, 2005, p. 11 n.2. The mud-brick wall of a chapel is clearly visible in Schneider et al., OMRO 75 (1995), pls. 1.1, 6.1; reproduced in Raven, Pay and Raia, 2005, pl. 5 (see also Staring, Saqqara Newsletter 16 [2018], fig. 3a-b). The position of this chapel is marked in the plan published by Schneider, Tomb of Iniuia, 2012, fig. II.1 (labelled “NN").

${ }^{4}$ Raven and van Walsem, Tomb of Meryneith, 2014, pp. 30, 76, figs. III.23, III.29. Second Dynasty Gallery E plus a later robbers' tunnel connect 2002/17 to the subterranean complex of Meryneith.

${ }^{5}$ I owe this information to Barbara Aston, who supervised the excavation in the southernmost part of the burial chamber.

${ }^{6}$ Raven et al., JEOL 37 (2003), p. 97, pl. 9, suggest that Mery-Iunu is the same man as Ramesses-em-perRe/Mery-Iunu, temp. Ramesses II-Merenptah (PM III/2, p. 715; Berlandini-Grenier, BIFAO 74 (1974). On stylistic grounds, I would rather date this Royal Butler later than Mery-Iunu of complex 2002/17.

${ }^{7}$ For the tomb of Tia, see Martin, Tomb of Tia, 1997.

${ }^{8}$ The ceramic material is currently being studied and prepared for publication. Initially, a date in the Nineteenth Dynasty was proposed (Aston, in Raven et al., JEOL 37 [2003], p. 102). Upon further study of the material, several of the wide, carinated marl-clay bases were found to belong to large Eighteenth Dynasty flasks (Barbara Aston, personal communication). This date corresponds to the suggested interment of the tomb owner, Ry.

${ }^{9}$ Raven et al., JEOL 44 (2012-13), pp. 9-11; Raven, Saqqara Newsletter 11 (2013), pp. 6-8. At the time, the Leiden archaeological mission was directed by Maarten J. Raven. Vincent Oeters and the present author (at the time a PhD student at Macquarie University, Sydney) acted as field supervisors. This section on the architecture of the tomb is partly based on the concept text written by Maarten J. Raven, who kindly shared with me his observations. A more detailed description and analysis of the tomb's architecture will appear in his chapter in the publication Five Tombs at Saqqara, which will also feature the tomb of Ry.

${ }^{10}$ Raven et al., JEOL 45 (2014-15), pp. 6-7. In 2015, the archaeological fieldwork project became a joint mission of the National Museum of Antiquities in Leiden and the Museo Egizio in Turin.

${ }^{11}$ Unbonded walls are not uncommon in the Saqqara New Kingdom necropolis. Examples of (fore-)courts constructed in this manner include Raia's extension in front of the tomb of Pay (Raven, Pay and Raia, 2005, pp. 11-12); the north ("phase 4") and south walls ("phase 2") of the court situated between the tombs of Meryneith and Ptahemwia (Raven and van Walsem, Tomb of Meryneith, 2014, pp. 68, 70); the wall between the tomb of Paser and the rear wall of the central chapel of Horemheb (Martin, Paser and Ra'ia, 1985, p. 3); and the wall between the tombs of Iniuia and Horemheb (Schneider et al., JEA 79 [1993], p. 4).

12 The "porch" was further excavated in 2015. I thank Paolo Del Vesco for sharing his views of this feature and the photographs taken during excavation.

${ }^{13}$ This external "rubble floor" (feature no. 2015/1) connects several chapels of Ramesside date, built north and east of the tomb of Ry: Raven, Saqqara Newsletter 15 (2017), pp. 14-16 and fig. 1.

${ }^{14}$ Raven, in Raven et al., JEOL 44 (2012-13), p. 11, suggests that this "unusual plan" is the result of the pre-existence of the tomb of Pay. He argues that access to the tomb of Pay "would have been blocked" should Ry have opted for a northwest chapel. Do note, however, that the northwest chapel of Pay hinders, in its own turn, an axial approach to the tomb of Iniuia further to the west. The construction of the tomb of Iniuia probably started a few years before the tomb of Pay (although the building and/or decoration of the two may have partly overlapped). In this example, an axial approach appears to have been of no major concern in tomb placement. Also note the positions of several tombs in the north sector of the Unas South Cemetery (the Cairo University concession area). The tomb of Tjay, ST 211, "blocks" the entrance to the tomb of Mahu, ST 218. In the east part of that cemetery, no less than three tombs are built in line. The entrance of the tomb of Nebmehyt, ST 7, almost touches the freestanding pyramid of Tasahuy, ST 5, and the west exterior wall of Nebmehyt is located right in front of the entrance to anonymous tomb ST 9 (Tawfik, MDAIK 47 [1991], fig. 1).

${ }^{15} \mathrm{~A}$ feature quite unlike any other New Kingdom tomb hitherto excavated in the Memphite necropolis. See: Schneider, Tomb of Iniuia, 2012, pp. 31-33, fig. II.2-4.

${ }^{16}$ See Hawass, Secrets from the Sand, 2003, pp. 154-55, fig. on p. 156; Youssef, The New Kingdom TombChapels, 2017, passim. For modest, single-chapel tomb superstructures at Thebes, see e.g. Polz, Der Beginn, 2007, pp. 239-45. For both Thebes and Saqqara, see also Raue, MDAIK 51 (1995), pp. 255-68.

${ }^{17}$ Raven, in Raven et al., JEOL 44 (2012-13), p. 10, argues that because "the rest of the tomb has no reliefs or inscriptions" it shows "all the signs of likewise being unfinished". This argument makes assumptions about the perceived emic "ideal" of what ancient Egyptian tombs should look like, while it actually reflects an etic ideal, conforming to the expectations of the modern researcher. It is not at all certain whether the tomb owner ever intended to provide the walls of the courtyard with a limestone revetment, even if the presence of a limestone revetment in the courtyards of Ry's necropolis neighbours (Pay, Meryneith, Ptahemwia, Horemheb) would strongly suggest otherwise.

${ }^{18}$ Raven et al., JEOL 45 (2014-15), p. 7. I am aware of no parallels for these features elsewhere in the New Kingdom necropolis at Saqqara. 
${ }^{19}$ Aston, in Raven et al., JEOL 44 (2012-13), p. 20; Aston, in Raven et al., JEOL 45 (2014-15), p. 16.

${ }^{20}$ Aston, in Raven et al., JEOL 44 (2012-13), p. 20. I thank Barbara Aston for kindly sharing with me her preliminary analysis of the pottery found in the tomb of Ry.

${ }^{21}$ Allowing for the thickness of the stone revetment on the north and south reveal.

${ }^{22}$ Compare to the height of the two columns from the contemporary chapel of Paatenemheb (Leiden AMT 1-35): 186 and $190 \mathrm{~cm}$; and those from the chapel of Iniuia: Berlin $\ddot{A M} 1627,152.5 \mathrm{~cm}$; and $\ddot{A M} 1628$, $152 \mathrm{~cm}$ (Schneider, Tomb of Iniuia, 2012, p. 75). No columns are known for the tomb of Ry, nor were any traces of their former presence noted during excavation. However, it would be very unlikely that no columns were used in the chapel, especially if the chapel roof had to support the weight of a mud-brick pyramid.

${ }^{23}$ The tomb of Iniuia provides a parallel for a pyramid built over a single tomb chapel: Schneider, Tomb of Iniuia, 2012, pp. 31-33, 35, fig. II.2-4. The side masses of Iniuia's pyramid consist of step-laid courses of bricks arranged slantwise along the north, west and south sides of the chapel. The pyramid of the unpublished tomb chapel of Khay II was constructed in a similar manner (I owe this information to Maarten J. Raven, who is currently preparing the chapel for publication in Five Tombs). At present, it is not entirely clear how the pyramid of Ry's chapel would have been constructed, and whether it would cover the chapel in part or in its entirety. Future archaeological fieldwork in the area surrounding the chapel exterior should resolve the issue.

${ }^{24}$ Staring, Saqqara Newsletter 16 (2018), pp. 31-46.

${ }^{25}$ For previous studies listing the inscribed and decorated stone elements from the tomb of Ry, see: PM III/2, pp. 715-16; Fründt, FuB 3/2 (1961), p. 27; Martin, Corpus of Reliefs, 1987, pp. 20-22, nos. 42-45, pls. 14-17 (additional line drawings were prepared by Geoffrey T. Martin, to be published in a forthcoming volume of his Corpus); Herzberg, in Kampp-Seyfried and Jung (eds.), China und Ägypten, 2017, pp. 198-99, fig. III.20.

${ }^{26}$ I would like to thank Yekaterina Barbash of the Brooklyn Museum for providing me with these measurements and for granting permission to publish this stela and relief-decorated block Brooklyn Museum 37.39E (see Fig. 21, below).

${ }^{27}$ Such hymns are also occasionally included in Book of the Dead spell 15a. For an analysis of sun hymns in Memphite tombs, see: Van Dijk, Phoenix 42/1 (1996). For sun hymns in mostly Theban tombs, see: Assmann, Sonnenhymnen, 1983.

${ }^{28}$ See Van Dijk, Phoenix 42/1 (1996).

${ }^{29}$ Schneider, Tomb of Iniuia, 2012, pp. 73-75 [8], fig. III.24-24a. Measurements (reconstructed): H. ca. $200 \mathrm{~cm}$, W. ca. $100 \mathrm{~cm}$, Th. ca. $25 \mathrm{~cm}$.

${ }^{30}$ Mariette, Monuments divers, 1872, pl. 57a; Van Dijk, Phoenix 42/1 (1996), pp. 16-19, fig. 4; Schneider, Tomb of Iniuia, 2012, pp. 71-73 [7], fig. III.23. Measurements: H. $187 \mathrm{~cm}$. Twelve lines of text under a lunette depicting a double adoration scene of Iniuia standing before Re-Horakhty and Atum. This stela was found by Mariette in March 1860: Pasquali, in Bárta et al. (eds.), Abusir and Saqqara, 2017, p. 578, no. 10079.

${ }^{31}$ Raven, Pay and Raia, 2005, pp. 42-46 [70], frontispiece, pls. 73-75; Raven et al., JEOL 42 (2010), pp. 14-16, fig. 12; Raven in Five Tombs, forthcoming, [6a-b] (including newly excavated fragments of the stela and e revised translation of the text). Height, as preserved, $195 \mathrm{~cm}$, W. ca. $125 \mathrm{~cm}$. Assmann, Ägyptische Hymnen, 1975 , no. 34, identifies the text as an excerpt of BD $15 \mathrm{a}$, and argues that the text is not a hymn, but a prayer of the deceased to the sun god so as to partake in the sun's cycle of death and rebirth. The parallels between the stela texts of Pay and Ry were already noted by Raven, Pay and Raia, 2005, p. 44 n. 70.

${ }^{32} \mathrm{PM}$ III/2, p. 308; Botti and Romanelli, Le sculture, 1951, pp. 77-78, no. 124, pl. 60. Measurements: H. $65 \mathrm{~cm}$, W. $68 \mathrm{~cm}$.

${ }^{33}$ Raven, Pay and Raia, p. 41, suggests that the stela might have stood against the original east facade of the tomb (later replaced by a stela of Pay's son Raia), because the south jamb of the antechapel entrance bears relief decoration.

${ }^{34}$ There are two Memphite parallels showing a person sitting on a stool positioned underneath a chair. The first is relief (or stela?) fragment Cairo TN 3.7.24.12 of Ptahmay, the Chief of Makers of Gold-Leaf of the temple of Aten (provenance: Kafr el-Batran near Giza, or Saqqara; late Eighteenth Dynasty, temp. Akhenaten). It shows Ptah-ankh seated on a stool (without a pillow), situated underneath (besides) the chair of his mother, Ty, as he rests one hand on his knee and with his other hand brings a lotus flower to his nose. See: Löhr, SAK 2 (1975), pp. 180-81, Doc. III 7a, pl. 6.2; C. Zivie, BIFAO 75 (1975), pp. 301-03, no. 5, pl. 56. The second parallel is rectangular stela Cairo CG 34049 (JE 18181) of Ahmose, the Scribe and Reckoner of Cattle [of the Overseer of the Seal] (found by Luigi Vassalli [1812-87] at Saqqara in January 1862; late Eighteenth Dynasty, temp. Amenhotep III, at the latest). It shows an anonymous lady seated on a stool (without a pillow), situated underneath the chair of Puhu, undoubtedly her mother, the wife of Ahmose. The lady rests one hand on her knee and with the other hand brings a lotus flower to her nose. One son of Puhu and Ahmose is called Ry, a $\underline{h} r d n k z p$. See: Lacau, Stèles du Nouvel Empire, 1909-16, pp. 84-86, pl. 29; Mariette, Monuments divers, 1872, p. 18, pl. 56a. For three-dimensional representations of the stool, cf. the statue of Hel, Turin Cat. 7352 (temp. Ramesses II), Poole, RiME 3 (2019), fig. 2 and pp. 12-13, with further references.

${ }^{35}$ Compare the tomb of the Overseer of Craftsmen of the Lord of the Two Lands, Amenemone: Ockinga, Amenemone, the Chief Goldsmith, 2004, scene [11], pl. 66.

${ }^{36}$ For parallels for this scene (i.e. the same composition), see: tomb of Pay, courtyard, south wall, west end (Raven, Pay and Raia, 2005, pp. 29-30, [22], pls. 34-35); tomb of Iniuia, antechapel, south wall 
(Schneider, Tomb of Iniuia, 2012, pp. 80-81, [15], fig. III.30, pl. 1; 76.5 x 87 x $8 \mathrm{~cm}$ ); and inner chapel, south wall (Schneider, Tomb of Iniuia, 2020, pp. 87-88 [20], fig. III.35, pl. $7 ; 75$ x 43.5 x $15 \mathrm{~cm}$ ).

${ }^{37}$ I would like to thank Friederike Seyfried, Caris-Beatrice Arnst and Anne Herzberg of the Ägyptisches Museum und Papyrussammlung, Berlin, for providing me with excellent photographs and for granting permission to publish the relief-decorated blocks and stela of Ry held in the museum's collection. ${ }^{38}$ Compare to the central offering bearer in scene [10].

${ }^{39}$ For stelae from Saqqara comprising superimposed scenes that are carved in sunk and raised relief, respectively, see e.g. round-topped stela of Thutmose, Vizier, formerly in the collection of Lord Nugent, acquired in Egypt in 1844, present location unknown (mid-Eighteenth Dynasty, temp. Amenhotep II; Blackman, JEA 4 [1917], pp. 40-41, pl. 10.2; Gessler-Löhr, in Kessler and Schulz [eds.], Gedenkschrift für Winfried Barta, 1995, p. 143, pl. 5b); stela Cairo CG 34054 of Amenmose, Head of the Quartermasters of the Army (late Eighteenth Dynasty, temp. Amenhotep III; Lacau 1906-16, pp. 95-97, pl. 32); stela Cairo TN 2.11.24.1 of Hatiay, Chief of Craftsmen of Ptah (late Eighteenth Dynasty: Mariette, Monuments divers, 1872, pp. 379-80, no. 1054 [as provenance Abydos]; Gaballa SAK 7 [1979], pp. 47-49, fig. 3, pl. 3); stela Leiden AP 56 of Djehuty, Overseer of Cattle of Amun (late Eighteenth-early Nineteenth Dynasty, temp Horemheb-Seti I: Boeser, Beschrijuing, Stèles, 1913, p. 11, no. 40, pl. 22); stela Cairo JE 25641 of Hatiay, Chief of Faience-makers (late Eighteenthearly Nineteenth Dynasty, temp. Seti I: Gaballa, SAK 7 [1979], p. 46, fig. 2, pl. 2).

${ }^{40}$ Compare to the group of six army officials depicted in the tomb of Horemheb (inner courtyard, east wall, south end): Martin, Memphite Tomb of Horemheb I, 1989, scene [69], pl. 85 [top], 86 (included in the current article as Fig. 23, see below). See also Hofmann, Bilder im Wandel, 2004, Appendix B, “Bekleidung”, no. 20 (“Militärschurz 2"). Cf. also the possible much earlier parallel of Nebansu, Custodian of the "Splendour of the Aten", stela Cairo CG $34055=$ JE 33107 (late Eighteenth Dynasty, temp. Amenhotep III, second half: Teti Pyramid Cemetery [Lacau 1909-1916, 98-99, pl. 33]).

${ }^{41}$ Binder, Gold of Honour, 2008, cat. No. [148].

${ }^{42}$ For the long staff held by Osiris at Saqqara, see also: stela Cairo JE 25641, Hatiay, Chief of FaienceMakers (late Eighteenth-early Nineteenth Dynasty, temp. Seti I: Gaballa, SAK 7 [1979], p. 46, fig. 2, pl. 2); relief-decorated block of Horemheb, General (Quibell, Excavations at Saqqara, 1912, pl. 72); stela Berlin ÄM 7315, Seba, Scribe of Divine Offerings in the House of Ptah (Nineteenth Dynasty); stela Berlin ÄM 7271, Raia, Overseer of the Royal Apartments at Memphis (late Eighteenth-early Nineteenth Dynasty, temp. Horemheb-Seti I; LD, III, pl. 242d); stela Leiden AP 52, Paatenemheb, Royal Butler (late Eighteenth Dynasty, temp. Horemheb; Boeser, Beschrijving, Stèles, 1911, 1-5, pls 1-18).

${ }^{43}$ The representation is remindful of the contemporaneous Saqqara stela of Amenhotep Huy and his son Ipy (Florence, Museo Archeologio Inv. no 2567), sitting vis-à-vis at a single offering table, unaccompanied by offering bearers (see Bosticco, Le stele egiziane, 1965, 39-39, no. 32; Pasquali and Gessler-Löhr, BIFAO 111 [2011], fig. 5). In addition, the stela of the Vizier Thutmosis (temp. Amenhotep II; see n. 35), in the lower register shows two ladies sitting vis-à-vis at an offering table. They are the vizier's wife, Nafy, and her (their) daughter Neferuptah. Both women are accompanied by a standing, naked boy: her son Wab and her brother (i.e. their son) Ptahankh, respectively. Unlike the examples of Ry/Maia and Amenhotep Huy/Ipy, Nafy and Neferuptah do not extend their arms over the offering table.

${ }^{44}$ For this observation, see: Gessler-Löhr, in Pasquali and Gessler-Löhr, BIFAO 111 (2011), p. 293.

${ }^{45}$ Cf. Raven and van Walsem, Tomb of Meryneith, 2014, p. 183 n. 252. Compare Ry (posture, garment, execution) to relief-decorated block Lisbon, Museu Calouste Gulbenkian inv. no. 205 of the General, Amenemone, a contemporary of Ry $(66 \times 36 \mathrm{~cm}$; Assam, Arte Egípcia,1991, pp. 62-63 [15]).

${ }^{46}$ Fründt, FuB 3/2 (1961), fig. 1; Martin, Corpus of Reliefs, 1987, pp. 20-21, no. 41, pl. 15.

${ }^{47}$ For an early Memphite representation of an officiant pouring a libation of water over a seated couple, see the stela of Thutmosis, Head of Custodians of the Gate in Memphis, temp. Amenhotep III (lower left corner; London, British Museum EA 155: HTBM 8, pp. 47-49, pl. 39). Water being poured over the standing couple was more frequently depicted. See e.g. the relief-decorated block Cairo JE 33260 of Mahu, Custodian of the Treasury of Ptah (Eighteenth Dynasty, temp. Amenhotep III; Gessler-Löhr, BACE 18 (2007), pl. 13); stela Cairo CG 34182 = JE 10174 of Huy, the Head of Merchants of the Temple of the Aten (Eighteenth Dynasty, temp. Amenhotep IV/Akhenaten; Mariette, Monuments divers, 1972, p. 18, pl. 56b). The relief-decorated block Cairo JE 46191 of the Overseers of Goldworkers Ptahemheb and Amenemheb (late Eighteenth/early Nineteenth Dynasty) shows Ptahemheb (?) standing unaccompanied by his wife as a priest pours a libation over him. A similar scene is depicted on a stela in the near-contemporary tomb of the Royal Nurse, Maia (late Eighteenth Dynasty, temp. Tutankhamun; tomb Bub. I.20: Zivie, La tombe de Maïa, 2009, pl. 3). The act of an officiant pouring a libation of water over a seated or standing couple (or their statue) is also common in representations of the Opening of the Mouth ritual. See, for example, NN, block Chicago, Field Museum 31291 (late Eighteenth Dynasty: Martin, Corpus of Reliefs, 1987, p. 13, [18], pls. 7, 43) and Meryneith, Greatest of Seers of the Aten in the Temple of the Aten (late Eighteenth Dynasty, temp. Akhenaten-Tutankhamun: Raven and van Walsem, Tomb of Meryneith, 2014, pp. 122-23, [29]). The same Opening of the Mouth ritual may also include the pouring of a libation of water over the standing mummy. See, for example, Mery-Mery, Custodian of the Treasury of Memphis (relief-decorated block Leiden AP 6-b, late Eighteenth 
Dynasty, temp. Amenhotep III: Giovetti and Picchi [eds.], Egitto: Splendore millenario, 2015, cat. V.23, pp. 260-61); and NN, joining blocks Havana, Museo Nacional de Belles Artes 94-15 and Birmingham, City Museums 688'66 (late Eighteenth Dynasty, temp. Horemheb/ early Nineteenth Dynasty: Álvarez Sosa et al., La Colección Egipcia, 2015, pp. 126-28; Martin, Corpus of Reliefs, 1987, p. 14, [21-22], pl. 8).

${ }^{48}$ The same garment is worn by Ry in scene [7], block Berlin ÄM 7275. See also Hofmann, Bilder im Wandel, 2004, appendix B, “Bekleidung”, no. 20 (“Militärschurz 1”).

${ }^{49}$ Compare Maia's hand to that of the unnamed son of Ptahemwia holding a bird (Raven, Ptahemwia and Sethnakht, forthcoming); and to that of a woman, holding a bird, on a relief-decorated block fragment TNM: B10 from the Teti Pyramid Cemetery (Ockinga, in Evans [ed.], Ancient Memphis, 2012, p. 390 no. 3, fig. 4). Both examples date to the immediate postAmarna period.

${ }^{50}$ BD Nav. 149l, lines 71-74. The correct BD chapter was already noted by Martin, Corpus of Reliefs, 1987, p. 46 n. $45 \mathrm{c}$ (although erroneously written as $14 \mathrm{gl}$ ). For BD 149, see also: Lüscher, Totenbuch Spruch 149/150, 2010; Quirke, Going Out in Daylight, 2013, p. 362. The origins of BD spell 1491 can be traced back to CT spell 278. See: Faulkner, The Ancient Egyptian Coffin Texts, 2004, pp. 209-10. For a more comprehensive discussion of the spell in context, see the section "Date, iconography and style: A synthesis", below. A chapter dedicated to BD 149 will also feature in the monograph in preparation by Walking Dead team member Huw Twiston Davies.

${ }^{51}$ I would like to thank Jacobus van Dijk, Boyo Ockinga, Huw Twiston-Davies and Roland Enmarch for valuable suggestions on the reading of parts of this text.

${ }^{52}$ As suggested to me by Jacobus van Dijk.

${ }^{53}$ I owe this observation to Federico Poole.

${ }^{54}$ These distinctive folds are also visible in scenes [9], Berlin $\ddot{A M} 7278$, and [5], Berlin ÄM 7277.

${ }^{55}$ The second offering bearer to the right in block Berlin ÄM 7277 similarly supports a bowl of exactly the same shape. In the tomb of Pay, an offering bearer supports, on his shoulder, an amphora as he holds it with both hands (Raven, Pay and Raia, 2005, scene [37], pls. 42-43).

${ }^{56}$ For the way in which the right-hand side offering bearer holds the bundle of papyrus stalks, compare to an offering bearer depicted in the tomb of Pay: Raven, Pay and Raia, 2005, scene [37], pls. 42-43.

${ }^{57}$ These traces are only visible when manipulating a digital photograph of this scene by enhancing colour separation using decorrelation stretching (DStretch).

${ }^{58}$ Judging from the opposite doorway south reveal, i.e. scene [2], the relief decoration may have been executed in raised relief. This observation leads us to another option for the revetment block which once decorated the doorway's north reveal: fragment Brooklyn 37.1505E ( 40.3 x 48.5 cm; Martin, Corpus of Reliefs, 1987, p. 26 [59], pls. 21, 50). It depicts offering bearers lined up in front of a pile of food offerings. The depicted figures are very similar to those featuring in the reliefs of Ry, stylistically. The offering bearers are facing left (thus "entering" the tomb), and the scanty traces of an upper register depict a monkey under a chair, facing right. Do note, however, that the in-situ fragment has a block frieze as a register line, whereas the Brooklyn fragment shows a single horizontal line.

${ }^{59}$ Fründt, FuB 3/2 (1961), p. 27.

${ }^{60}$ In an earlier study of the corpus, I was not yet convinced of the block's provenance from the tomb of Ry: Staring, Saqqara Newsletter 16 (2018), p. 41.

${ }^{61}$ I would like to thank Benedetta Torrini (Polo Museale della Toscana, Museo Archeologico Nazionale di Firenze) for kindly providing me with the photograph produced for her catalogue of Egyptian objects held in the Studium Biblicum Franciscanum Museum, and for granting permission to publish it here.

${ }^{62}$ The closest parallel is presented by the lintel of Iniuia, east side: Schneider, Tomb of Iniuia, 2012, p. 76 [11], fig. III.26. The lintel, measuring $30 \times 194$ x $25 \mathrm{~cm}$ (height, width, thickness) is decorated on the east and west side, and was originally positioned on top of the two papyrus-bundle columns in the entrance to the chapel.

${ }^{63} \mathrm{~A}$ lengthier discussion and in-depth analysis of style and iconography will appear in the final publication of the tomb of Ry (Five Tombs), to be edited by the former field-director of the Leiden mission at Saqqara, Maarten J. Raven.

${ }^{64}$ For a more detailed analysis of style in tombs dated to this time-period, the reader is referred to Raven, Pay and Raia, 2005, pp. 53-56 (tomb of Pay and Raia); Gessler-Löhr, in Pasquali and Gessler-Löhr, BIFAO 111 (2011), pp. 291-96 (tomb of Ipy, Chief Steward in Memphis); Hofmann, Bilder im Wandel, 2004, pp. 97-101 (style of Memphite tombs dated to Tutankhamun-Horemheb); Herzberg, Z ̈̈̈S 143/1 (2016), pp. 34-59. Berlandini, in L'égyptologie en 1979, p. 212, already suggested that the relief-decorated blocks of Ry were executed in the "style of Horemheb", which she argues is the same as observed in the tombs of the Overseer of the Treasury Maya, the Goldsmith Amenemone, the General Amenemone, the Scribe of the Treasury Ptahnefer, and the Royal Scribe Ptahmose (in fact the early Ramesside Mayor of Memphis). The style observed in the reliefs of all officials is indeed quite comparable, although close scrutiny of the material reveals slight differences between the officials as well as within the corpus of each tomb individually (see e.g. Staring, BIFAO 114/2 [2014], pp. 455-518). While Berlandini had to work with loose relief blocks, we now have the advantage of having the rediscovered tombs at our disposal, and thus additional textual and iconographic material, as well as archaeological evidence, to substantiate our arguments.

${ }^{65}$ Compare, for example, the offering bearers on the east wall of the courtyard of the tomb of Pay (Raven, Pay and Raia, 2005, pp. 50-56, scene [37], pls. 42-43), between chapel and "vestibule E", with those in scene [10] in the tomb of Ry.

${ }^{66}$ Raven, Pay and Raia, 2005, pp. 53-56. 
${ }^{67}$ Courtyard, south wall, west end (Raven, Pay and Raia, 2005, pp. 29-30, [22], pls. 34-35).

${ }^{68}$ Antechapel, south wall (Schneider, Tomb of Iniuia, 2012, pp. 80-81, [15], fig. III.30, pl. 1) and inner chapel, south wall (Schneider, Tomb of Iniuia, 2012, pp. 87-88 [20], fig. III.35, pl. 7.

${ }^{69}$ Compare the position assumed by the daughter of Iniuia, Merytre, who sits on the foot stool of her father. In the depiction, she appears to be sitting on her father's feet. A very similar representation graces the north wall of the antechapel of tomb 135 (anonymous, badly preserved; Ramesside date), excavated by the Leiden-Turin expedition to Saqqara in 2017 (Del Vesco and Weiss, Saqqara Newsletter 15 [2017], fig. 9). It is possible that the artist responsible for the latter relief-decorated block drew inspiration from the nearby tomb of Iniuia.

70 The tombs of Pay and Paatenemheb also include movement in the opposite direction, i.e. the tomb owner "leaving" the tomb. In the example of Pay, the east faces of the screen walls separating the antechapel from the inner chapel depict the tomb owner striding towards the doorway, thus entering the sanctuary (Raven, Pay and Raia, 2005, scenes [48-49], pls. 50-51), and the west faces show him striding towards the same doorway, leaving the sanctuary (Raven, Pay and Raia, 2005, scenes [51, 57], pls. 52-53). As he is "exiting" the tomb, Pay is given the double staff (the $w 3 s$ and $m d w$ ) and two pieces of cloth. In the tomb chapel of Paatenemheb, the owner is given the same attributes on the east wall (west face), north part, as he faces the Fields of Iaru (BD 110), depicted on the same wall, on opposite sides of the doorway (Boeser, Beschrijving, Graven, 1911, pls. 5, 12). The staff marks the deceased's newly acquired status of life after death (Staring, BIFAO 114/2 [2014], p. 483). The deceased has entered the tomb as a place where the god receives his offerings, and where he is "being given a staff" (cf. the contemporary tomb of Maya: Martin, Tomb of Maya, 2012, p. 30, scene [30]).

${ }^{71}$ TT 11, Djehuty, Dra Abu el-Naga North, Eighteenth Dynasty, temp. Hatshepsut-Thutmosis III/Amenhotep II (Díaz-Iglesias Llanos, in Staring et al. [eds.], Perspectives on Lived Religion, 2019, p. 152; Galán, in Galán et al. [eds.], Creativity and Innovation, 2014, p. 257); TT 32, Thutmosis, Khokha, Nineteenth Dynasty temp. Ramesses II (Kákosy et al., Djehutymes [TT 32], 2004, pp. 232-33, fig. on p. 53); TT 353, Senenmut, Deir el-Bahri, Eighteenth Dynasty temp Hatshepsut (Dorman, The Tombs of Senenmut, 1991, pp. 126-33; BD 1491: p. 131, pl. 73); TT 359, Inherkhau, Deir el-Medina, Twentieth Dynasty, temp. Ramesses III-IV (Saleh, Das Totenbuch, 1984, p. 83: exclusively vignettes, illustrating four mounds).

${ }^{72}$ Milde, Book of the Dead of Neferrenpet, 1991, p. 113. Compare also the papyrus of Yuya, in which BD 149-150 (texts and vignettes) feature quite elaborately: Davis, The Funeral Papyrus of Iouiya, 1908, pls. 30-35. In the Ramesside period, the "preferred choice" of the final vignette includes BD 110 (depicting the Fields of Iaru) and BD 186 (depicting the Hathor cow emerging from the West Mountain, protecting the tomb chapel). They replace the fiery and difficult to traverse regions of the underworld as illustrated by BD 149. The regions described in BD 149 are said to be the BD version of the Two Ways of Rosetau, separated by the Lake of Fire, as described in the CT (Milde, in Bremer et al. [eds.], Hidden Futures, 1994, pp. 32-33). Lucarelli (The Book of the Dead of Gatgeshen, 2006, pp. 173-74) points to the problematic fact that the mounds thus described are not at all pleasant places, whereas their placement at the end of BD manuscripts seem to suggest that they form the final point of destination of the deceased.

${ }^{73}$ Milde, Book of the Dead of Neferrenpet, 1991, p. 114.

${ }^{74}$ See, for example, the relief-decorated blocks from the Saqqara tomb of NN, joining blocks Havana, Museo Nacional de Belles Artes 94-15 and Birmingham, City Museums 688'66 (late Eighteenth Dynasty, temp. Horemheb/ early Nineteenth Dynasty: Álvarez Sosa et al., La Colección Egipcia, 2015, pp. 126-28; Martin, Corpus of Reliefs, 1987, p. 14, [21-22], pl. 8). For Theban examples, see e.g. the scenes published in Hofmann, Bilder im Wandel, 2004: Amenmose, TT 19 (pl. 6, fig. 14); Khons, TT 31 (pl. 7, fig. 15); Amenemone, TT 277 (pl. 11, fig. 31); Ramose, TT 250 (pl. 16, fig. 47); Kenro, TT 178 (pl. 25, fig. 69). In the tomb of Ry's necropolis neighbour to the north, Meryneith, the Opening of the Mouth ritual is depicted on the north wall of the courtyard (Raven and Van Walsem, Tomb of Meryneith, scenes 28-30).

${ }^{75}$ I owe this observation to Maarten Raven.

${ }^{76}$ Copenhagen, Nationalmuseet AA.d.11 (H. $50 \mathrm{~cm}$, W. $30.2 \mathrm{~cm}$ ): Davies, Who's Who at Deir el-Medina, 1999, pp. 176-78; Manniche, Egyptian Art in Denmark, 2004, p. 200, no. 90 . For the ritual of offering and purification, compare the final stages of the Opening of the Mouth ceremony: Otto, Das ägyptische Mundöffnungsritual, 1960, pp. 153-55, scenes 69B-C.

${ }^{77}$ Or, alternatively, Osiris. Compare the contemporary tombs of Pay (Raven, Pay and Raia, 2005, pp. 36-38 $[53,55]$, pls. 56-57) and Paatenemheb (Boeser, Beschrijving, Graven, 1911, pp. 1-5, pls. 1-18), showing the same disposition of scenes. The chapels of Pay and Paatenemheb are broader and therefore all scenes are depicted on the west wall, on either side of the cult stela.

${ }^{78}$ See e.g. Weiss, in Verschoor et al. (eds.), Imaging and Imagining, 2017, pp. 215-29, with further references to recent scholarship on the subject. Weiss (Id., p. 218) notes that for the New Kingdom only a handful of examples are known for the combined worship of Oriris and Re on a single stela, and that they all derive from Saqqara, perhaps pointing to a Memphite tradition. The disposition of the adoration scenes of Re and Osiris in the chapel of Ry likely hint at the same underlying concept, even though the scenes are differently arranged, i.e. not together on one stela, but displayed on three walls which together form the focus of the cult chapel. Note, for example, that the offering formulae framing the stela (̈̈M 7290) invoke Osiris and Re-Horakhty, respectively.

${ }^{79}$ See the observations in Staring, BIFAO 114/2 (2014), 
pp. 484-87 (embrace no. 4).

${ }^{80}$ Relief Munich Gl 298: Ockinga, Amenemone, the Chief Goldsmith, 2004, pp. 60-63, scene [6B], pls. 13, 61.

${ }^{81}$ Schneider, Tomb of Iniuia, 2012, pp. 78-79 [13], fig. III.28, pl. 1.

${ }^{82}$ Leiden AP 9: PM VIII/4, no. 803-045-300; Boeser, Beschrijving, Stèles, 1913, pp. 4-5, pl. 4.

${ }^{83}$ One may also compare it to the hand of Anuy in the tomb of her husband, Meryneith, Ry's neighbour to the north: Raven and van Walsem, Tomb of Meryneith, scene [29]; Staring, BIFAO 114/2 (2014), fig. 5.

${ }^{84}$ On the professional association of patron and artist (studies of Theban tombs), see Hartwig, Tomb Painting and Identity, 2004; Laboury, in Jasnow and Cooney (eds.), Joyful in Thebes, 2015, pp. 327-37.

${ }^{85}$ Raedler, in Gundlach and Taylor (eds.), Egyptian Royal Residences, 2009, p. 149.

${ }^{86}$ Raedler, in Beinlich (ed.), "Die Männer hinter dem König”, 2012, p. 129.

${ }^{87}$ Raedler, in Gundlach and Taylor (eds.), Egyptian Royal Residences, 2009, p. 147; Raedler, in Beinlich (ed.), “Die Männer hinter dem König”, 2012, pp. 129-30.

${ }^{88}$ Raedler, in Gundlach and Taylor (eds.), Egyptian Royal Residences, 2009, p. 147.

${ }^{89}$ Compare the epithet $m r r n b=f h r$ bỉ.t=f(Iny, Overseer of the Gold Workers of the Lord of the Two Lands; stela Cairo JE 15115; late Eighteenth/early Nineteenth Dynasty: Mariette, Monuments divers, 1872, p. 20, pl. 62b); $m r r n b=f$ hr bỉ.t=f ikr.t (Serbekhen Iby, Prophet of Amun, Astarte, and Baal; wooden staff Berlin ÄM 1284; Ramesside: LD Text I, p. 16). See also: $h s . y$ n.y $n s w$ hr bỉ.t=f, "one praised by the king on account of his character" (Ramose, Deputy of the army; tomb at Saqqara; late Eighteenth Dynasty, temp. Tutankhamun-Horemheb; Martin, Three Memphite Officials, 2001); $w^{\top} i k r r$ [hr] bỉ.t=f, "uniquely excellent [on account of] his character" (Seba, Scribe of the Treasury of Ptah; stela Berlin ÄM 7315; early Nineteenth Dynasty; Roeder, Aegyptische Inschriften 2, 1924, pp. 172-73); nb hs.wt hr mdw.t $r 3=f[n b m r . w t$ $h r]$ bi.t $f$ f $n f r . w$ (Sakeh, Mayor of Memphis; Vienna, Kunsthistorische Museum 5816; late Eighteenth Dynasty, temp. Tutankhamun-Horemheb; GesslerLöhr, OMRO 77 (1997), pp. 57-58, pl. 10); bỉ.t=f ik $r d i$ $m r . w t=f$, "his excellent character, which causes the love of him" (Ptahmose, Mayor of Memphis; relief Nasher Museum of Art 1984.2.3; early Nineteenth Dynasty, temp. Seti I-Ramesses II; Staring, BACE 25 [2014], p. 122).

${ }^{90}$ Raedler, in Gundlach and Taylor (eds.), Egyptian Royal Residences, 2009, pp. 131-51; Guksch, Königsdienst, 1994, p. 40.

${ }^{91}$ James, Corpus of Hieroglyphic Inscriptions, 1974, pp. 175-76 [431].

${ }_{92}$ Gnirs, Militär und Gesellschaft, 1996, p. 660.

${ }^{93}$ Two officials built their tombs in the Teti Pyramid Cemetery: Ahmose, late Eighteenth/early Nineteenth Dynasty, tomb Loret no. 1 (Málek, JEA 75 [1989], p. 69); Huy, late Eighteenth Dynasty, temp. Ay-Horemheb, tomb Lepsius LS 12 = Quibell S 2735 (with additional titles his.y n.y ntr $n f r ; s \check{s} n s w ; s \breve{s}$ nsw n.y nb t3.wy: PM III/2, p. 556; Ockinga, in Evans [ed.], Ancient Memphis, 2012, pp. 374-77). The location of the third, Tena, of Ramesside date, is lost (title recorded on palette Berlin ÄM 8042: PM III/2, p. 773).

${ }^{94}$ Gnirs, Militär und Gesellschaft, 1996, p. 66. Similarly, the Old Kingdom and Middle Kingdom title im.y-r3 $m n f y$. $t$ can be considered synonymous to the New Kingdom im.y-r3 mšc, military official (Gnirs, Militär und Gesellschaft, 1996, pp. 12-17). Mnfy.t/mnf3.t is translated with "soldiers" or "infantry".

${ }^{95}$ Gnirs, Militär und Gesellschaft, 1996, p. 66. Gnirs lists two other officials for whom this uncommon combination of titles (military and scribal) is evident: Horemheb, TT 78 (Overseer of all Royal Scribes of the Army); and Huy, a son of the Vizier of the North, Aper-El (tomb Bubasteion I.1: š́ nfr.w n.y nb t3.wy). One may also add the General, Amenemone, who held the title $s \check{s} n f r . w t$, recorded on relief block Museo Archeologico Nazionale di Parma E.108 (Botti, I cimeli Egizi, 1964, pp. 56-63, no. 108, pl. 15).

${ }^{96}$ Schulman, Military Rank, Title, and Organization, 1964, pp. 51-53. Note that Schulman lists Ry among the fourteen individuals bearing this title in the Eighteenth Dynasty (ref. 400: Berlin ÄM 7578, 7290) as well as among the fifteen bearers of the title in the Nineteenth Dynasty (ref. 406: Brooklyn 37.46E).

${ }^{97}$ Schulman, Military Rank, Title, and Organization, 1964, p. 47. Schulman suggests the same for the title im.y-r3 $m \check{s}$, denoting a "military officer" in the infantry.

${ }^{98}$ Gnirs, Militär und Gesellschaft, 1996, pp. 29-31, 66-70.

${ }^{99}$ Gnirs, Militär und Gesellschaft, 1996, p. 21; Urk. IV, p. 1895,15. The first to bear the title im.y-r3 ssm.wt $n$ $n b$ t3.wy, Nakhtmin (Urk. IV, p. 1179,8), did so in the reign of Thutmosis III. At the time it was not a military office, but one related to the state administration.

${ }^{100}$ Gnirs, Militär und Gesellschaft, 1996, p. 21.

${ }^{101}$ Schulman, Military Rank, Title, and Organization, 1964, pp. 46-47.

${ }^{102}$ E.g.: Huy (temp. Ramesses II; stela Cairo TN 5.11.24.9: Lowle, SAK 9 [1981], pp. 253-58, pl. 5; hr.y-pd.t written as hr.y-nb.t; his other title was StandardBearer of the Great Company of Usermaatre-Setepenre Beloved of Amun); Nebneheh (Nineteenth Dynasty; dyad Cairo CG 597; Borchardt 1925, 150-51, pl. 107); Nehemay (Eighteenth Dynasty, temp. Amenhotep III[?]; stela Cairo CG 34098; Lacau 1926, 151-52, pl. 46). In addition, the General and Steward of the Theban Ramesseum, Ramessesnakht (Nineteenth Dynasty, temp. Ramesses II, early), bore the title $\underline{t} s w$ pd.t, Troop-Commander (basin Turin, Museo Egizio Cat. 1755: Berlandini, BIFAO 79 [1979], pp. 43-54).

${ }^{103}$ Gnirs, Militär und Gesellschaft, 1996, pp. 67, 70.

${ }^{104} \mathrm{~A}$ third, possibly Memphite bearer of the combination of titles is observed on his canopic jar Brussels E 5894, for which a Saqqara provenance has been suggested: Gnirs, Militär und Gesellschaft, 1996, p. 66.

${ }^{105}$ LD., III, 241b; Martin, Tomb of Maya, 2012, p. 33 [36-37], 64, pls. 28-29.

${ }^{106}$ Excavation no. R94-83: Raven, Pay and Raya, 2005, p. 47 [75], pl. 79.

${ }^{107}$ On the cult stela of his father Pay, Raia, identified as Stablemaster, is clad in a soldier's sash kilt: Raven, Pay and Raia, 2005, scene [54], pls. 58-59. 
${ }^{108}$ Raven, Pay and Raia, 2005, infra.

${ }^{109}$ Gnirs, Militär und Gesellschaft, 1996, p. 188, ns. 1269-70; also Raven, Pay and Raia, 2005, p. 7.

${ }^{110}$ His brother, Hatiay, and his uncle (a brother of his father, Pay), also named Hatiay, both held office as Stablemasters: Raven, Pay and Raia, 2005, p. 2.

${ }^{111}$ PM III/2, p. 733; Martin, Three Memphite Officials, 2001, pp. 1-9. Loose block SAK 2009-R 23 (unpublished) is inscribed with his name and part of the title: /// n.y $n b$ t3.wy.

${ }^{112}$ Zivie, in Evans (ed.), Ancient Memphis, 2012, pp. 438-39. A list of the titles held by Huy is given in a text column on the north-east pillar of tomb Bub. I.1: Zivie, BAR 44/4 (2018), p. 29, fig. on p. 24; Zivie, in Vittozzi (ed.), Egyptian Curses 1, 2014, pp. 92-93, fig. 5 on p. 91 . The upper part of the text is missing, obliterating much of the first, unidentifiable title. The title Scribe of $n f r . w$ ("recruits") occurs on the inner coffin of Huy. I wish to thank Alain Zivie for information and sharing with me a high resolution line drawing of the pillar text.

${ }^{113}$ Daoud et al, EA 48 (2011), pp. 7-9; Youssef, Sokar 23 (2011), pp. 84-89; Willeitner, AW 24/3 (1993), p. 258.

${ }^{114}$ Two officials bearing these titles and dated to the reign of Amenhotep III had their tombs (now lost) built in the Teti Pyramid Cemetery. They are: Tjay, im.y-r3 ssm.wt n.t nb t3.wy (ebony statue Cairo JE 33255 = Loret NI 197, now displayed in the Luxor Museum: PM III/2, 553; Gessler-Löhr, BACE 18 [2007], pp. 73-74, no. 7, pl. 8) and Wesy, hr.y-pd.t n.y $n b$ t3.wy (stela Munich ÄS 11 [the name of the god Amun erased] and two canopic jars formerly in the collection of Lord Nugent (full titulary: ir.y $r d$.wy $n n b$ tz.wy; tzzy-sry.t n.y ḥ3.t-nfr.w-Imn; hrr.y-pd.t (n.y nb t3.wy): PM III/2, p. 718; Blackman, JEA 4 (1917), pp. 42-43, pl. 11.6-7; Löhr and Müller, Staatliche Sammlung Ägyptischer Kunst, 1972, p. 64, cat. 49b, pl. 34).

${ }^{115}$ See Schulman, JARCE 2 (1963), pp. 87, 94-95. Schulman notes that while the Stablemasters' titles imply that they were chariotry officers, their protocols show them mostly originating from an infantry background. That this is not incompatible is evidenced by the examples of Stablemasters in the tomb of Ry. They served an official who held a command in both the infantry and the chariotry. For the administration of the stables, see also Ashmawy Ali, Ä\&L 24 (2014), pp. 121-39; and for their social standing, see: Katary, in Hoffmeier and Meltzer (eds.), Egyptological Miscellanies, 1983, esp. p. 73-74.

${ }^{116}$ Raven, Pay and Raia, 2005, p. 2.

${ }^{117}$ Oeters, in Verschoor et al. (eds.), Imaging and Imagining, 2017, p. 69.

${ }^{118}$ Raven et al., JEOL 42 (2010), pp. 6-9.

${ }^{119}$ Relief-decorated block SAK 2009-R19: Raven et al., JEOL 42 (2010), fig. 6.

${ }^{120}$ The lost tomb of Amenhotep III's Chief Steward in Memphis, Amenhotep Huy, should also be situated in this section of the necropolis: PM III/2, p. 702-3; Hayes, JEA 24 (1938), pp. 9-24. See also Raven et al., Memphite Tomb of Horemheb, 2011, p. 39, for pitgraves dated to the reign of Amenhotep III. One such pit-grave contained the coffin inscribed for a $s \underline{d m}$ - ‘š: Raven et al., Memphite Tomb of Horemheb, 2011, pp. 39, 72. Some of the tombs dated to the reigns of Akhenaten-Horemheb are in fact built by officials whose careers started in the reign of Amenhotep III.

${ }^{121}$ Staring, in Giovetti and Picchi (eds.), Egypt: Millenary Splendour, 2016, pp. 210-15, with further references. Compare to the contemporary rock-cut tombs in the cliffs near the later Bubasteion at Saqqara North, incl. Aper-El (Bub. I.1), Ptahmose (Bub. II.x): Zivie, in Evans (ed.), Ancient Memphis, 2012, pp. 425-43.

${ }^{122}$ Raven, Pay and Raia, 2005, pp. 82-83, cat. 115 (with further references). Note that some of the bricks stamped with the praenomen of Amenhotep II were excavated from the fill of Ry's burial shaft (Weiss, Saqqara Newsletter 13 [2015], pp. 46-50; Raven et al., JEOL 45 [2014-15], p. 7). The title "Lector Priest of Amenhotep II" held by Neferhat son of Ipu (temp. Tutankhamun; see n. 68, above), may refer to his office in the Memphite memorial temple of Amenhotep II. The L-shaped section of a massive wall made of mud bricks stamped with the praenomen of Amenhotep II has been excavated close to the Unas causeway, some $200 \mathrm{~m}$ north/northwest of the tomb of Ry (Lacher, Grab des Ninetjer, 2014, pls. 2, 18e, 42f; stamped name misread as Horemheb). It is not known what sort of building this wall was part of. However, in light of its dimensions, a royal monument might be more likely than a private tomb structure.

${ }^{123}$ Textual sources from the Theban necropolises suggest that state bureaucracy was not involved in keeping records pertaining to the tombs and cults of individuals (Sheikholeslami, in Jurman et al. [eds.], A True Scribe of Abydos, 2017, pp. 416-17).

${ }^{124}$ Raven, Pay and Raia, 2005.

${ }^{125}$ Raven and van Walsem, Tomb of Meryneith, 2014.

${ }^{126}$ The anonymous tomb which in this phase neighboured Ry to the east was excavated in 2010 (Raven et al., JEOL 43 [2011], pp. 3-18). This tomb is now referred to in the literature as the "tomb of Sethnakht”, after an individual whose shabti was found in the burial chamber, who was not the original occupant of the tomb (Raven et al., Ptahemwia and Sethnakht, forthcoming). Proposed date of the tomb: temp. Tutankhamun-Ramesses II (Hays, in Bárta et al. [eds.], Abusir and Saqqara, 2011, pp. 84-105) or Akhenaten-Tutankhamun (contemporaneous with Ptahemwia and Meryneith: Raven et al., Ptahemwia and Sethnakht, forthcoming). The tomb situated south of Ry has not been excavated yet.

${ }^{127}$ Staring, in Bárta et al. (eds.), Abusir and Saqqara, 2017, pp. 593-611.

${ }^{128}$ The omission of the southeast chapel of Pay could be indicative of another pre-existing structure situated to the south of it.

${ }^{129}$ Raven et al., JEOL 44 (2012-13), p. 11, suggests that Raia was responsible for the partial destruction of Ry's mud-brick pyramid, because Raia built his forecourt right against the base of the pyramid. This seems unlikely, because Raia evidently went to the trouble of creating a north approach, far removed from the pyramid. Moreover, the forecourt he created is asymmetrical, and clearly reckons with the pre- 
existing pyramid of Ry. Besides, there is no clear evidence to propose a likely date for the eventual destruction of the pyramid.

${ }^{130}$ Raven, Saqqara Newsletter 15 (2017), pp. 15, 14, figs. 1, 3: feature 2017/8 (anonymous).

${ }^{131}$ Raven et al., JEOL 45 (2014-15), p. 13, fig. 11 (feature 2015/11).

${ }^{132}$ Oeters, in Verschoor et al. (eds.), Imaging and Imagining, 2017.

${ }^{133}$ Raven et al., JEOL 44 (2012-13), p. 11, figs. 6-7 (feature 2013/7).

${ }^{134}$ Staring, in Bárta et al. (eds.), Abusir and Saqqara, 2017.

${ }^{135}$ See e.g. Staring, JEOL 45 (2014-15), with further references.

${ }^{136} \mathrm{~A}$ Memphite memorial temple of this king, probably located due west of Memphis (Pasquali, Topographie cultuelle, 2011, p. 10 [A.19]). The Memphite memorial temple of Thutmosis III has not been identified archaeologically; however, members of its priesthood are known as late as the Saite Period (Pasquali, Topographie cultuelle, 2011, pp. 10-12). Haring, Divine Households, 1997, p. 432, assigns Amenemone to the Theban memorial temple of Thutmosis III.

${ }^{137}$ See: PM III/2, p. 701; Djuževa, in Bárta and Krejčí (eds.), Abusir and Saqqara, 2000, pp. 77-98. Note that Djuževa's Dok. 9 is no longer held in a private collection in Brussels, but in a private collection in Paris (I owe this information to Anne Herzberg). As of this writing, Dok. 8, the relief-decorated block held in the collection of James G. Hanes Jr., Winston-Salem, North Carolina, is being offered for sale (I owe this reference to Lara Weiss).

${ }^{138}$ LD Text I, p. 138-139. The blocks described by Lepsius are now in Copenhagen, Ny Carlsberg Glyptotek ÆIN Inv. no. 714-15. Recently, a number of blocks found reused in the foundations of houses in the village of Menawat near Abusir have been identified as deriving from the tomb of Horemheb: Johnson and Hawass, in Van Dijk (ed.), Another Mouthful of Dust, pp. 323-34.

${ }^{139}$ Gessler-Löhr, in Feucht (ed.), Vom Nil zum Neckar, 1986, pp. 72-73; Djuževa, in Bárta and Krejčí (eds.), Abusir and Saqqara, 2000, p. 79.

${ }^{140}$ Staring, in Bárta et al. (eds.), Abusir and Saqqara, 2017, table 5.

${ }^{141}$ Martin, Memphite Tomb of Horemheb I, 1989.

${ }^{142}$ Staring, BIFAO 114/2 (2014), pp. 496-97; Staring, JEOL 45 (2014-15); Staring, JEA 102 (2016), pp. 165-69.

${ }^{143}$ Gnirs, Militär und Gesellschaft, 1996, pp. 53-54, 68. Another official who took the same unusual path in his career, and whose tomb is located in the same general area of the necropolis at Saqqara, is Iurokhy/ Urhiya, a General in the early Nineteenth Dynasty. His military titles are: hr.y-pd.t n.y $n b$ t3.wy and im.y$r 3 m s^{\complement} w r$. Iurokhy also served as a Steward in the Theban Ramesseum and as a Steward of the King. His previously lost tomb (Lepsius LS 25) has recently been re-excavated in the Cairo University concession area of the Unas South Cemetery at Saqqara: https:// www.livescience.com/62514-ancient-general-tombsaqqara.html, accessed 3 July 2018. See also: PM III/2, p. 661; Staring, JEOL 45 (2014-15), pp. 74-76; Van
Dijk, in van Dijk (ed.), Another Mouthful of Dust, 2016, pp. 91-106.

${ }^{144}$ Gnirs, Militär und Gesellschaft, 1996, pp. 54, 100-101; Gnirs, SAK 16 (1989), pp. 83-110.

${ }^{145}$ See e.g. Polz, MDAIK 42 (1986), pp. 145-66; Kawai, JEH 3/2 (2010), p. 268.

${ }^{146}$ Gnirs, Militär und Gesellschaft, 1996, p. 67.

${ }^{147}$ Paramessu first briefly served as General: Gnirs, Militär und Gesellschaft, 1996, p. 102. Another official, Nakhtmin, held titles similar to Amenemone. For the (changing) relationship between Nakhtmin and Horemheb, see: Kawai, JEH 3/2 (2010), pp. 261-92.

${ }^{148}$ Construction work on Horemheb's Memphite tomb may have continued when he was king. The subterranean complex, for example, was "directly modelled on the royal tombs of the last kings of the Eighteenth Dynasty before the Amarna period" (Van Dijk, The New Kingdom Necropolis of Memphis, 1993, p. 46). The first pylon and forecourt may have also been constructed at that time (see also Raven et al., Memphite Tomb of Horemheb, 2011, p. 27).

${ }^{149}$ Dawson et al., Who Was Who, 2012, p. 418.

${ }^{150}$ Passalacqua, Catalogue raisonné, 1826. For the reliefdecorated blocks from the tomb of Ry, see: pp. 55-56 [1378] (Berlin $\ddot{A} M$ 7275); pp. 72 - 73 [1405] (Berlin ÄM 7278); p. 73 [1406] (Berlin ÄM 7277).

${ }^{151}$ The stone elements bearing the names of tomb owners include: the Outline Draughtsman of Re, Iuty (stela ÄM 7269; PM III/2, p. 732); Overseer of the Double Granary of Upper and Lower Egypt, Wepwawetmose (stela ÄM 7316; PM III/2, p. 734); Head of Custodians of Documents of the Temple, Penamun (stela ÄM 7307; PM III/2, p. 733); Scribe of the Altar of the Royal Apartments, Panehesy (stela ÄM 7317; PM III/2, p. 733); Chief Sculptor, Pagerger (column base ÄM 2286; PM III/2, p. 708); High Priest of Ptah, Ptahmose (pyramidion $\ddot{A} M$ 2276; PM III/2, p. 712-713); Brewer of the temple of Ptah, Ptahmose (stela ÄM 7321; PM III/2, p. 733); Overseer of Cattle of Amun, Minmose (stela ÄM 822; PM III/2, p. 734); Sem Priest, Merenptah (stela ÄM 7276; PM III/2, p. 733); Chief of Goldsmiths of the Lord of the Two Lands, Meryptah (stela ÄM 7279; PM III/2, p. 733); Servant, Nehehenitef (stela ÄM 7273; PM III/2, p. 733); Deputy of the Army, Ramose (stela ÄM 7306; PM III/2, p. 733); Gold-Washer of the Lord of the Two Lands, Khay (stela ÄM 7314; PM III/2, p. 733); Head of Custodians of the Lord of the Two Lands, Khay (stela ÄM 7281; PM III/2, p. 733); Scribe of Documents of the Chief Steward, S (stela ÄM 7272; PM III/2, p. 734); Scribe of the God's Offerings of the House of Ptah, Seba (stela ÄM 7315; PM III/2, p. 734); Sectional Chief of the New PoultryYards of [the temple of] Ptah, Kem (stela ÄM 7289; PM III/2, p. 733); and Mayor of 'Anu, Teti (canopic jars ÄM 7171, 7173; PM III/2, p. 773).

${ }^{152}$ Schneider, Memphite Tomb of Horemheb, 1996, p. 94 [NK 19], pl. 102.

${ }^{153}$ Excavation number SAK 2009-R 31. The relief fragment only preserves the text "the Osiris, Scribe of the Offering Table", without the name of the titlebearing official. Raven, Five Tombs, forthcoming, [49]. ${ }^{154}$ Martin, Tomb of Tia and Tia, 1997, p. 48, no. 341, 
pl. 100; Raven et al., Memphite Tomb of Horemheb, 2011, p. 64, no. 39, fig. on p. 65.

${ }^{155}$ Martin, Three Memphite Officials, 2001, pp. 7-8 [3], fig. 3, pls. 1, 4, 46.

${ }^{156}$ Martin, Three Memphite Officials, 2001, pp. 15-16 [8], fig. 4, pls. 1, 12, 56 .

${ }^{157}$ Staring, in Verschoor et al. (eds.), Imaging and Imagining, 2017, pp. 100-101. The current LeidenTurin expedition to Saqqara recently excavated a number of robbery pits possibly dating to this period. A palm-leaf basket was also found, associated with a number of dismantled blocks of Ramesside chapel 135 , all left behind by nineteenth-century diggers. Del Vesco et al., RiME 3 (2019), p. 8, figs. 1, 2, 8.

${ }^{158} \mathrm{~L} D$, pl. I.31. Note that the location of LS 28 on Lepsius' map and the description given in LD, I, p. 184 n. 1, do not correspond to their actual location: Raven, Pay and Raia, 2005, pp. xxi-xxii.

${ }^{159}$ Dawson et al., Who Was Who, 2012, pp. 1-2; Raver, BES 13 (1997), pp. 39-45.

${ }^{160}$ Bonomi, Catalogue of a Collection, 1846.

${ }^{161}$ Abbott, Catalogue of a Collection, 1854, preface.

${ }^{162}$ Abbott, Catalogue of a Collection, 1854, introduction.

${ }^{163}$ Mariette, Monuments divers, 1872, pp. 558-59, no. 1432; PM V, p. 74.

${ }^{164}$ Rammant-Peeters, Les pyramidions, 1983, p. 25.

${ }^{165}$ Paris, Bibliothèque national de France, MS NAF 21167: "Fouilles de S.A. le vice-roi - Journal servant à l'enregistrement des monuments au fur et à mesure de leur découverte" (July 1860-December 1863): Pasquali, in Bárta et al. (eds.), Abusir and Saqqara, 2017, p. 570, no. 14975.

${ }^{166}$ Pasquali, in Bárta et al. (eds.), Abusir and Saqqara, 2017, pp. 96-97.

${ }^{167}$ Quibell, Excavation at Saqqara, 1908, pp. 63-69.

${ }^{168}$ Torrini, in Rosati and Guidotti (eds.), Proceedings of the XI International Congress of Egyptologists, 2017, p. 656.

${ }^{169}$ According to Piccirillo, Studium Biblicum Franciscanum, 1983, p. 79, with fig. (followed by Martin, Corpus of Reliefs, 1987, p. 22. no. 45, pl. 14), Steinhausen (sic.) acquired the objects before 1914 in Alexandria.

${ }^{170}$ According to the museum website (http:// studiumbiblicum.org, last accessed on 22.11.2019) it was first opened in 1902 and, after the foundation of the Studium Biblicum Franciscanum in 1924, the archaeological museum relocated to the Flagellation Monastery, where it continued to receive objects from excavations conducted by Franciscan excavators. According to the information provided in Piccirillo, Studium Biblicum Franciscanum, 1983, p. 79, Steinhauser presented his collection to the Studium Biblicum Franciscanum at the beginning of the British Mandate (1922), and according to Torrini, in Rosati and Guidotti (eds.), Proceedings of the XI International Congress of Egyptologists, 2017, p. 656, this happened "probably shortly before his death in 1927". The recently drafted inventory of the collection by Torrini includes includes 26 fragmentary reliefs and doorjambs. The full inventory is currently being prepared for publication. Martin's Corpus of Reliefs, 1987, lists seven relief-decorated blocks with a likely Memphite provenance as ex-coll. Steinhauser: nos. 16,
45 (Ry), 54 (Royal Scribe and Steward, Ipy: the son of the Steward Amenhotep Huy), 89 (///y), 97 (/// of pharaoh, l.p.h., Amunemwia), 99, 106. Nearly all blocks were sawn on one or more sides. In case of Ry, the top, right side, lower edge and back were sawn and the relief shows traces of considerable modern repair. For the relief of Ipy (SBF 06212), see also Torrini, in Rosati and Guidotti (eds.), Proceedings of the XI International Congress of Egyptologists, 2017, p. 658-59, fig. 4. Torrini argues for an Amarna provenance, which seems, however, very unlikely.

\section{Bibliography}

Abbott, H., Catalogue of a Collection of Egyptian Antiquities, the Property of Henry Abbott, M.D. Now Exhibiting at the Stuyvesant Institute, No. 659 Broadway, New York, New York 1854.

Álvarez Sosa, M., A. Chicuri Lastra, and I. Morfini, La Colección Egipcia del Museo Nacional de Belles Artes de la Habana / The Egyptian Collection of the National Museum of Fine Arts in Havana, Havana 2015.

Ashmawy Ali, A., "The Administration of Horse Stables in Ancient Egypt”, Ä\&L 24 (2014), pp. 121-39.

Assam, M.H., Arte Egípcia: colecçao Calouste Gulbenkian, Lisbon 1991.

Assmann, J., Liturgische Lieder an den Sonnengott: Untersuchungen zur altägyptischen Hymnik, I. (MÄS 19), Berlin 1969.

Assmann, J., Ägyptische Hymnen und Gebete: eingeleitet, übersetzt und erläutert von Jan Assmann, Zürich 1975.

Assmann, J., Sonnenhymnen in thebanischen Gräbern (Theben 1), Mainz 1983.

Aston, B.G., "The Pottery”, in M.J. Raven, R. van Walsem, B.G. Aston, and E. Strouhal, "Preliminary Report on the Leiden Excavations at Saqqara, Season 2002: The Tomb of Meryneith", JEOL 37 (2003), pp. 101-02.

Aston, B.G., "Study of Pottery", in M.J. Raven, H.M. Hays, B.G. Aston, L. Horáčková, N. Warner, and M. Neilson, "Preliminary Report on the Leiden Excavations at Saqqara, Season 2009: The Tombs of Khay II and Tatia”, JEOL 42 (2010), pp. 17-18.

Aston, B.G., "Study of Pottery", in M.J. Raven, H.M. Hays, B.G. Aston, R. Cappers, B. Deslandes, and L. Horáčková, "Preliminary Report on the Leiden Excavations at Saqqara, Season 2010: An Anonymous Tomb”, JEOL 43 (2011), pp. 13-14.

Aston, B.G., “Study of Pottery', in M.J. Raven, B.G. Aston, L. Horáčková, D. Picchi, and A. Bleeker, "Preliminary Report on the Leiden Excavations at Saqqara, Season 2013: The Tombs of Sethnakht and an Anonymous Official", JEOL 44 (2012-13), pp. 20-22.

Aston, B.G., "Pottery”, in M.J. Raven, L. Weiss, B.G. Aston, S. Inskip, and N. Warner, "Preliminary Report on the Leiden-Turin Excavations at Saqqara, Season 2015: The Tomb of an Anonymous Official (Tomb X) and Its Surroundings", JEOL 45 (2014-15), pp. 16-17.

Baud, M. and É. Drioton, Le tombeau de Rö̈ (tombeau no. 255) (MIFAO 57.1), Cairo 1928.

Berlandini-Grenier, J., "Le dignitaire Ramesside Ramsèsem-per-Rê”, BIFAO 74 (1974), pp. 1-19.

Berlandini, J., "Varia Memphitica III - Le general RamsèsNakht”, BIFAO 79 (1979), pp. 249-65. 
Berlandini, J., "Les tombes amarniennes et d'époque Toutânkhamon à Sakkara. Critères stylistiques”, in Anonymous (ed.), L'égyptologie en 1979 : axes prioritaires de recherches, Tome II, Paris 1982, pp. 195-212.

Binder, S., The Gold of Honour in New Kingdom Egypt (ACE-Stud. 8), Oxford 2008.

Blackman, A.M., "The Nugent and Haggard Collections of Ancient Egypt", JEA 4 (1917), pp. 39-46.

Boeser, P.A.A., Beschrijving van de Egyptische verzameling in het Rijksmuseum van Oudheden te Leiden: De monumenten van het Nieuwe Rijk. Eerste afdeeling: Graven, The Hague 1911.

Boeser, P.A.A., Beschrijving van de Egyptische verzameling in het Rijksmuseum van Oudheden te Leiden: De monumenten van het Nieuwe Rijk. Derde afdeeling: Stèles, The Hague 1913.

Bonomi, J., Catalogue of a Collection of Egyptian Antiquities, the Property of Henry Abbott, Cairo 1846.

Bosticco, S., Museo Archeologico di Firenze: le stele egiziane del Nuovo Regno, Rome 1965.

Botti, G., I cimeli egizi del Museo di Antichità di Parma (Accademia Toscana di Scienze e Lettere "La Colombaria”: studi 9), Florence 1964.

Botti, G. and P. Romanelli, Le sculture del Museo Gregoriano Egizio (Monumenti vaticani di archeologia e d'arte 9), Vatican 1951.

Daoud, K., “The Tomb of the Royal Envoy Nakht-Min”, EA 38 (2011), pp. 7-9.

Daoud, K., S. Farag, and C. Eyre, "Nakht-Min: Ramesses II's Charioteer and Envoy”, EA 48 (2016), pp. 9-13.

Davies, B.G., Who's Who at Deir el-Medina. A Prosopographic Study of the Royal Workmen's Community (EU 13), Leiden 1999.

Davis, T.M., The Funeral Papyrus of Iouiya (Theodore M. Davis' Excavations 3), London 1908.

Dawson, W.R., U.P. Uphill, and M.L. Bierbrier, Who Was Who in Egyptology, $4^{\text {th }}$ rev. ed., London 2012.

Del Vesco, P., C. Greco, M. Müller, N. Staring, and L. Weiss, "Current Research of the Leiden-Turin Archaeological Mission in Saqqara. A Preliminary Report on the 2018 Season", RiME 3 (2019), DOI: https://doi. org/10.29353/rime.2019.2236.

Del Vesco, P. and L. Weiss, "A Brief Report on the 2017 Season (2): The Leiden-Turin Expedition to Saqqara: Excavating to the North of Maya's Tomb", Saqqara Newsletter 15, pp. 19-26.

Díaz-Iglesias Llanos, L., "Human and Material Aspects in the Process of Transmission and Copying the Book of the Dead in the Tomb of Djehuty (TT 11)", in N. Staring, H.P. Twiston Davies, and L. Weiss (eds.), Perspectives on Lived Religion: Practices - Transmission - Landscape, Leiden 2019, pp. 147-64.

Djuževa, O., "Das Grab des Generals Ameneminet in Saqqara”, in M. Bárta and J. Krejčí (eds.), Abusir and Saqqara in the Year 2000 (ArOr-Suppl. 9), Prague 2000, pp. 77-98.

Dorman, P.F., The Tombs of Senenmut: The Architecture and Decoration of Tombs 71 and 353 (PMMA 24), New York 1991.

Erman, A., Ausführliches Verzeichnis der aegyptischen Altertümer und Gipsabgüsse, Berlin 1899.
Faulkner, R.O., The Ancient Egyptian Coffin Texts: Spells 1-1185 \& Indexes, Warminster 2004.

Fründt, E., "Eine Gruppe memphitischer Grabreliefs des Neuen Reiches”, FuB 3/2 (1961), pp. 25-31.

Gaballa, G.A., “False Door Stelae of Some Memphite Personnel”, SAK 7 (1979), pp. 41-52.

Galán, J.M., "The Inscribed Burial Chamber of Djehuty (TT 11)”, in J.M. Galán, B.M. Bryan and P.F. Dorman (eds.), Creativity and Innovation in the Reign of Hatshepsut: Papers from the Theban Workshop 2010 (SAOC 69), Chicago 2014, pp. 247-72.

Gessler-Löhr, B., "Reliefblock aus dem Grab des Generalissimus Amen-em-inet”, in E. Feucht (ed), Vom Nil zum Neckar: Kunstschätze Ägyptens aus Pharaonischer und Koptischer Zeit an der Universität Heidelberg, Berlin 1986, pp. 72-73.

Gessler-Löhr, B., "Bemerkungen zur Nekropole des Neuen Reiches von Saqqara vor der Amarna-Zeit, I: Gräber der Wesire von Unterägypten”, in D. Kessler and R. Schulz (eds.), Gedenkschrift für Winfried Barta: htp dj $n$ h.j. (MÄU 4), Frankfurt am Main 1995, pp. 133-57.

Gessler-Löhr, B., "Bemerkungen zur Nekropole des Neuen Reiches von Saqqara vor der Amarna-Zeit, II: Gräber der Bürgermeister von Memphis”, OMRO 77 (1997), pp. 31-61.

Gessler-Löhr, B., "Pre-Amarna Tomb Chapels in the Teti Cemetery North at Saqqara”, BACE 18 (2007), pp. 65-108.

Gessler-Löhr, B., “The Provenance of the Block and Ipy's Tomb at Saqqara”, in S. Pasquali and B. Gessler-Löhr, "Un nouveau relief du grand intendant de Memphis, Ipy, et le temple de Ptah du terrain-bẹ”, BIFAO 111 (2011), pp. 287-96.

Giovetti, P. and D. Picchi, Egitto: Splendore millenario. La collezione di Leiden a Bologna, Milano 2015.

Gnirs, A.M., "Haremhab - ein Staatsreformator? Neue Betrachtungen zum Haremhab-Dekret”, SAK 16 (1989), pp. 83-110.

Gnirs, A.M., Militär und Gesellschaft: ein Beitrag zur Sozialgeschichte des Neuen Reiches (SAGA 17), Heidelberg 1996.

Guksch, H., Königsdienst: zur Selbstdarstellung der Beamten in der 18. Dynastie (SAGA 11), Heidelberg 1994.

Haring, B.J.J., Divine Households: Administrative and Economic Aspects of the New Kingdom Royal Memorial Temples in Western Thebes (EU 12), Leiden 1997.

Hartwig, M., Tomb Painting and Identity in Ancient Thebes, 1419-1372 BCE (Monumenta Aegyptiaca 10), Turnhout 2004.

Hawass, Z.H., Secrets from the Sand: My Search for Egypt's Past, New York 2003.

Hayes, W.C., "A Writing-Palette of the Chief Steward Amenhotep and Some Notes on Its Owner", JEA 24 (1938), pp. 9-24.

Hays, H., "On the Architectural Development of Monumental Tombs South of the Unas Causeway at Saqqara from the Reigns of Akhenaten to Ramses II", in M. Bárta, F. Coppens, and J. Krejčí (eds.), Abusir and Saqqara in the Year 2010, Prague 2011, I, pp. 84-105.

Herzberg, A., "Zu den memphitischen Grabreliefs in der Sammlung des Ägyptischen Museums - Georg Steindorff - der Universität Leipzig”, ZÄS 143/1 
(2016), pp. 34-59.

Herzberg, A., “Grabstele des Ry und seiner Frau Maja”, in F. Kampp-Seyfried and M . Jung (eds.), China und Ägypten: Wiegen der Welt, Berlin 2017, pp. 198-99.

Hofmann, E., Bilder im Wandel. Die Kunst der ramessidischen Privatgräber (Theben 17), Mainz 2004.

HTBM 8 = Edwards, I.E.S., Hieroglyphic Texts from Egyptian Stelae, etc. Part 8, London 1939.

James, T.G.H., Corpus of Hieroglyphic Inscriptions in the Brooklyn Museum, Brooklyn 1974.

Johnson, W.R., and Z. Hawass, "The Abusir Tutankhamun Relief Blocks: Origin and Context”, in J. van Dijk (ed.), Another Mouthful of Dust. Egyptological Studies in Honour of Geoffrey Thorndike Martin (OLA 246), Leuven 2016, pp. 323-34.

Kákosy, L., T.A. Bács, Z. Bartos, Z.I. Fábián, and E. Gaál, The Mortuary Monument of Djehutymes (TT 32) (StudAeg Series Maior 1), Budapest 2004.

Katary, S.L.D., "Cultivator, Scribe, Stablemaster, Soldier: The Late-Egyptian Miscellanies in Light of P. Wilbour”, in J.K. Hoffmeier and E.S. Meltzer (eds.), Egyptological Miscellanies: A Tribute to Professor Ronald J. Williams, Chicago 1983, pp. 71-93.

Kawai, N., "Ay Versus Horemheb: The Political Situation in the Late Eighteenth Dynasty Revisited", JEH 3/2 (2010), pp. 261-92.

Laboury, D., "On the Master Painter of the Tomb of Amenhotep Sise, Second High Priest of Amun Under the Reign of Thutmose IV (TT 75)", in R. Jasnow and K.N. Cooney (eds.), Joyful in Thebes: Egyptological Studies in Honor of Betsy M. Bryan (Material and Visual Culture of Ancient Egypt 1), Atlanta 2015, pp. 327-37.

Lacau, P., Stèles du Nouvel Empire, CGC Nos 34001-34064, 34065-34189, Cairo 1909-16.

Lacher, C., Das Grab des Königs Ninetjer in Saqqara: architektonische Entwicklung frühzeitlicher Grabanlagen in Ägypten (AV 125), Wiesbaden 2014.

LD = Lepsius, C.R., Denkmäler aus Aegypten und Aethiopien, Leipzig 1897-1913.

Löhr, B., "Ahanjāti in Memphis”, SAK 2 (1975), pp. 139-87.

Löhr, B. and H.W. Müller, Staatliche Sammlung Ägyptischer Kunst, Munich 1972.

Lucarelli, R., The Book of the Dead of Gatseshen. Ancient Egyptian Funerary Religion in the $10^{\text {th }}$ Century $B C$ (EU 21), Leiden 2006.

Lüscher, B., Totenbuch Spruch 149/150 (Totenbuchtexte - Synoptische Textausgabe nach Quellen des Neuen Reiches 6), Basel 2010.

Málek, J., "An Early Eighteenth Dynasty Monument of Sipair from Saqqâra”, JEA 75 (1989), pp. 61-76.

Manniche, L., Egyptian Art in Denmark, Copenhagen 2004.

Mariette, A., Monuments divers recueillis en Egypte et en Nubie, Paris 1872.

Mariette, A., Catalogue général des monuments d'Abydos découverts pendant les fouilles de cette ville, Paris 1880.

Martin, G.T., The Tomb-Chapels of Paser and Ra'ia at Saqqâra (EES EM 52), London 1985.

Martin, G.T., Corpus of Reliefs of the New Kingdom from the Memphite Necropolis and Lower Egypt, London 1987.

Martin, G.T., The Memphite Tomb of Horemheb, Commanderin-Chief of Tut'ankhamu' $n$, I: The Reliefs, Inscriptions, and Commentary (EES EM 55), London 1989.
Martin, G.T., The Hidden Tombs of Memphis. New Discoveries from the Time of Tutankhamun and Ramesses the Great, London 1991.

Martin, G.T., The Tomb of Tia and Tia: A Royal Monument of the Ramesside Period in the Memphite Necropolis (EES EM 58), London 1997.

Martin, G.T., The Tombs of Three Memphite Officials: Ramose, Khay and Pabes (EES EM 66), London 2001.

Martin, G.T., The Tomb of Maya and Meryt, I: The Reliefs, Inscriptions, and Commentary (EES EM 99), London 2012.

Milde, H., The Vignettes in the Book of the Dead of Neferrenpet (EU 7), Leiden 1991.

Milde, H., “ 'Going Out into the Day.' Ancient Egyptian Beliefs and Practices Concerning Death", in J.M. Bremer, T.P.J. van den Hout, and R. Peters (eds.), Hidden Futures. Death and Immortality in Ancient Egypt, Anatolia, the Classical, Biblical and Arabic-Islamic World, Amsterdam 1994, pp. 15-34.

NYHS = Catalogue of the Egyptian Antiquities of the New York historical Society, New York 1915.

Ockinga, B.G., Amenemone, the Chief Goldsmith: A New Kingdom Tomb in the Teti Cemetery at Saqqara (Australian Centre for Egyptology: Reports 22), Oxford 2004.

Ockinga, B.G., "Evidence for New Kingdom Tomb Structures in the Teti Pyramid Cemetery North: Insights from the Macquarie Excavations", in L. Evans (ed.), Ancient Memphis 'Enduring is the Perfection': Proceedings of the International Conference held at Macquarie University, Sydney on August 14-15, 2008 (OLA 214), Leuven 2012, pp. 371-95.

Oeters, V., "The Tomb of Tatia, Wab-priest of the Front of Ptah and Chief of the Goldsmiths", in V. Verschoor, A.J. Stuart, and C. Demarée (eds.), Imaging and Imagining the Memphite Necropolis: Liber Amicorum René van Walsem (EU 30), Leiden 2017, pp. 57-80.

Otto, E., Das ägyptische Mundöffnungsritual (ÄgAbh 3), Wiesbaden 1960.

Pasquali, S., Topographie cultuelle de Memphis 1. a-Corpus: Temples et principaux quartiers de la XVIII dynastie (Cahiers « Égypte Nilotique et Méditerranéenne » 4), Montpellier 2011.

Pasquali, S., "Les fouilles d'Auguste Mariette à Saqqara (1858-1875). Les tombeaux du Nouvel Empire”, in M. Bárta, F. Coppens, and J. Krejčí (eds.), Abusir and Saqqara in the Year 2015, Prague 2017, pp. 557-82. Pasquali, S. and B. Gessler-Löhr, "Un nouveau relief du grand intendant de Memphis, Ipy, et le temple de Ptah du terrain-b`h", BIFAO 111 (2011), pp. 287-96.

Passalacqua, J., Catalogue raisonné et historique des antiquités découvertes en Égypte, Paris 1826.

Piccirillo, M., Studium Biblicum Franciscanum, Jerusalem, Jerusalem 1983.

Polz, D., “Die Särge des (Pa)-Ramessu”, MDAIK 42 (1986), pp. $145-66$.

Polz, D., Der Beginn des Neuen Reiches: zur Vorgeschichte einer Zeitenwende (SDAIK 31), Berlin 2007.

Poole, F., "Flawed and Fine? The Statue of Hel in the Museo Egizio, Turin (Cat. 7352)", RiME 3 (2019). DOI: https://doi.org/10.29353/rime.2019.2808.

Quibell, J.E., Excavations at Saqqara (1906-1907), 
Cairo 1908.

Quibell, J.E., Excavations at Saqqara (1908-9, 1909-10):

The Monastery of Apa Jeremias, Cairo 1912.

Quirke, S., Going Out in Daylight: prt $m$ hrw. The Ancient Egyptian Book of the Dead: Translation, Sources, Meanings (GHP Egyptology 20), London 2013.

Raedler, C., "Rank and Favour at the Early Ramesside Court”, in R. Gundlach and J.H. Taylor (eds.), Egyptian Royal Residences: 4. Symposium zur ägyptischen Königsideologie / $4^{\text {th }}$ Symposium on Egyptian Royal Ideology, London, June $1^{\text {st }}-5^{\text {th }} 2004$ (KSG 4/1), Wiesbaden 2009, pp. 131-51.

Raedler, C., “,Kopf der Schenut” — politische Entscheidungsträger der Ära Ramses’ II., in H. Beinlich (ed.), 6. Symposium zur ägypischen Königsideologie / 6th Symposium on Egyptian Royal Ideology „Die Männer hinter dem König“ (KSG 4/3), Wiesbaden 2012, pp. 123-50.

Rammant-Peeters, A., Les pyramidions égyptiens du Nouvel Empire (OLA 11), Leuven 1983.

Ranke, H., Die ägyptischen Personennamen, Glückstadt 1935.

Raue, D., “Zum memphitischen Privatgrab im Neuen Reich”, MDAIK 51 (1995), pp. 255-68.

Raven, M.J., The Tomb of Pay and Raia at Saqqara (EES EM 74), Leiden 2005.

Raven, M.J., “A Brief Report on the 2013 Season”, Saqqara Newsletter 11 (2013), pp. 5-11.

Raven, M.J., “A Brief Report on the 2017 Season (1): The South Sector”, Saqqara Newsletter 15 (2017), pp. 10-18.

Raven, M.J. et al., Five New Kingdom Tombs at Saqqara, forthcoming.

Raven, M.J. et al., The Tombs of Ptahemwia and Sethnakht (PALMA 22), Leiden forthcoming.

Raven, M.J., B.G. Aston, L. Horáčková, D. Picchi, and A. Bleeker, "Preliminary Report on the Leiden Excavations at Saqqara, Season 2013: The Tombs of Sethnakht and an Anonymous Official", JEOL 44 (2012-13), pp. 3-21.

Raven, M.J., H.M. Hays, B.G. Aston, L. Horáčková, N. Warner, and M. Neilson, "Preliminary Report on the Leiden Excavations at Saqqara, Season 2009: The Tombs of Khay II and Tatia”, JEOL 42 (2010), pp. 5-24.

Raven, M.J., H.M. Hays, B.G. Aston, R. Cappers, B. Deslandes, and L. Horáčková, “Preliminary Report on the Leiden Excavations at Saqqara, Season 2010: An Anonymous Tomb", JEOL 43 (2011), pp. 3-18.

Raven, M.J. and R. van Walsem, The Tomb of Meryneith at Saqqara (PALMA 10), Turnhout 2014.

Raven, M.J., R. van Walsem, B.G. Aston, and E. Strouhal, "Preliminary Report on the Leiden Excavations at Saqqara, Season 2002: The Tomb of Meryneith", JEOL 37 (2003), pp. 71-89.

Raven, M.J., V. Verschoor, M. Vugts, and R. van Walsem, The Memphite Tomb of Horemheb, Commander-inChief of Tutankhamun, V: The Forecourt and the Area South of the Tomb with Some Notes on the Tomb of Tia (PALMA 6), Turnhout 2011.

Raven, M.J., L. Weiss, B.G. Aston, S. Inskip, and N. Warner, "Preliminary Report on the Leiden-Turin Excavations at Saqqara, Season 2015: The Tomb of an Anonymous
Official (Tomb X) and Its Surroundings", JEOL 45 (2014-15), pp. 3-17.

Raver, W.S., "The Sad Egyptological Career of Dr. Henry Abbott, M.D.”, BES 13 (1997), pp. 39-45.

Regulski, I., C. Lacher and A. Hood, "Preliminary Report on the Excavations in the Second Dynasty Necropolis at Saqqara: Season 2009", JEOL 42 (2010), pp. 25-53.

Roeder, G., Ägyptische Inschriften aus den Staatlichen Museen zu Berlin, II: Inschriften des Neuen Reichs, Leipzig 1924.

Saleh, M., Das Totenbuch in den thebanischen Beamtengräbern des Neuen Reiches: Texte und Vignetten (AV 46), Mainz 1984.

Schneider, H.D., The Memphite Tomb of Horemheb, Commander-in-Chief of Tut'ankham凶n, II: A Catalogue of the Finds (EES EM 60), Leiden 1996.

Schneider, H.D., The Tomb of Iniuia in the New Kingdom Necropolis of Memphis at Saqqara (PALMA 8), Turnhout 2012.

Schneider, H.D., G.T. Martin, J. van Dijk, B.G. Aston, R. Perizonius, and E. Strouhal, "The Tomb of Iniuia: Preliminary Report on the Saqqara Excavations, 1993", JEA 79 (1993), pp. 1-9.

Schneider, H.D., G.T. Martin, J. van Dijk, B.G. Aston, R. Perizonius, and E. Strouhal, “The Tomb-Complex of Pay and Rai'a: Preliminary Report on the Excavations, 1994 Season”, OMRO 75 (1995), pp. 13-31.

Schulman, A.R., "The Egyptian Chariotry: A Reexamination", JARCE 2 (1963), pp. 75-98.

Schulman, A.R., Military Rank, Title, and Organization in the Egyptian New Kingdom (MÄS 6), Berlin 1964.

Sheikholeslami, C.M., "Some Theban Choachytes of the Third Intermediate Period”, in C. Jurman, B. Bader, and D.A. Aston (eds.), A True Scribe of Abydos: Essays on First Millennium Egypt in Honour of Anthony Leahy (OLA 265), Leuven 2017, pp. 415-44.

Staring, N., "A Relief from the Tomb of the Memphite Mayor Ptahmose in the Nasher Museum of Art at Duke University", BACE 25 (2014), pp. 117-46.

Staring, N., "The Tomb of Ptahmose, Mayor of Memphis: Analysis of an Early Nineteenth Dynasty Funerary Monument at Saqqara”, BIFAO 114/2 (2014), pp. 455-518.

Staring, N., "The Personnel of the Theban Ramesseum in the Memphite Necropolis”, JEOL 45 (2014-15), pp. 51-92.

Staring, N., "The History and Topography of a New Kingdom Necropolis", in P. Giovetti and D. Picchi (eds.), Egypt: Millenary Splendour. The Leiden Collection in Bologna, Milan 2016, pp. 210-15.

Staring, N., "The Tomb of Ptahemwia, 'Great Overseer of Cattle' and 'Overseer of the Treasury of the Ramesseum', at Saqqara”, JEA 102 (2016), pp. 145-70.

Staring, N., "The Mid-Nineteenth Century Exploration of the Saqqara New Kingdom Necropolis", in V. Verschoor, A.J. Stuart, and C. Demarée (eds.), Imaging and Imagining the Memphite Necropolis: Liber Amicorum René van Walsem (EU 30), Leiden 2017, pp. 95-113.

Staring, N., “Toward a Prosopography of New Kingdom Tomb Owners in the Memphite Necropolis", in M. Bárta, F. Coppens, and J. Krejčí (eds.), Abusir and 
Saqqara in the Year 2015, Prague 2017, pp. 593-611. Staring. N., "Keys to Unlocking the Identity of 'Tomb X': Introducing Horemheb's Army Official, Ry”, Saqqara Newsletter 16 (2018), pp. 31-46.

Staring, N., "Piecing Together the Dispersed Tomb of Ry at Saqqara”, EgArch 54 (2019), pp. 41-45.

Stewart, H.M., "Traditional Egyptian Sun Hymns of the New Kingdom”, BIA 6 (1966), pp. 29-74.

Tawfik, S., "Recently Excavated Ramesside Tombs at Saqqara, 1. Architecture”, MDAIK 47 (1991), pp. 403-09.

Torrini, B., "From Egypt to the Holy Land: First Issues on the Collection of the Egyptian Collection in the Studium Biblicum Franciscanum, Jerusalem", in G. Rosati and M.C. Guidotti (eds.), Proceedings of the XI International Congress of Egyptologists, Florence Egyptian Museum, Florence, 23-30 August 2015, Oxford 2017, pp. 656-60.

Van Dijk, J., “The New Kingdom Necropolis of Memphis: Historical and Iconographical Studies" (PhD thesis, Rijksuniversiteit Groningen), Groningen 1993.

Van Dijk, J., "Hymnen aan Re en Osiris in Memphitische graven van het Nieuwe Rijk", Phoenix 42/1 (1996), pp. 3-22.

Van Dijk, J., "A Statue of Yupa and His Wife Nashaia in the New Kingdom Necropolis at Saqqara”, in J. Van Dijk (ed.), Another Mouthful of Dust: Egyptological Studies in Honour of Geoffrey Thorndike Martin (OLA 246), Leuven 2016, pp. 91-106.

Weiss, L., "New Evidence of Amenhotep II at Saqqara", Saqqara Newsletter 13 (2015), pp. 46-50.

Weiss, L., "I am Re and Osiris", in V. Verschoor, A.J. Stuart, and C. Demarée (eds.), Imaging and Imagining the Memphite Necropolis. Liber Amicorum René van Walsem
(EU 30), Leiden and Leuven 2017, pp. 215-29.

Willeitner, J., "Ein neu entdecktes Grab bei Abusir in Ägypten”, AW 24/3 (1993), p. 258.

Youssef, M.M., "Die Ausgrabungen südlich des Grabes des Nachtmin in Sakkara-Nord”, Sokar 23 (2011), pp. 84-89.

Youssef, M.M., “The New Kingdom Tomb-Chapels at the Teti Cemetery in Saqqara, According to Recent Discoveries" (PhD thesis, Cairo University), Cairo 2017.

Zivie, A.-P., La tombe de Maïa, mère nourricière du roi Toutânkhamon et Grande du Harem (Bub. I.20) (Les tombes du Bubasteion à Saqqara 1), Toulouse 2009.

Zivie, A.-P., “Amenhotep III et l'Ouest de Memphis”, in L. Evans (ed.), Ancient Memphis: 'Enduring Is the Perfection': Proceedings of the International Conference Held at Macquarie University, Sydney on August 14-15, 2008 (OLA 214), Leuven 2012, pp. 425-43.

Zivie, A.-P., "Le vizir et père du dieu 'Aper-El ('Abdiel)", in G. Capriotti Vittozzi (ed.), Egyptian Curses 1: Proceedings of the Egyptological Day Held at the National Research Council of Italy (CNR), Rome, $3^{\text {rd }}$ December 2012 in the International Conference "Reading Catastrophes: Methodological Approaches and Historical Interpretation. Earthquakes, Floods, Famines, Epidemics Between Egypt and Palestine, $3^{\text {rd }}-1^{\text {st }}$ Millennium BC. Rome, $3^{\text {rd }}-4^{\text {th }}$ December 2012, CNR - Sapienza University of Rome" (Archaeological Heritage \& Multidisciplinary Egyptological Studies 1), Rome 2014, pp. 85-99.

Zivie, A.-P., "Pharaoh's Man, 'Abdiel: The Vizier with a Semitic Name”, BAR 44/4 (2018), pp. 23-31, 64-65.

Zivie, C.M., "À propos de quelques reliefs du Nouvel Empire au Musée du Caire: I. La tombe de Ptahmay à Giza”, BIFAO 75 (1975), pp. 285-310. 